\title{
ESTUDO COMPARATIVO DA EFICÁCIA DA FONOFORESE, DO ULTRA-SOM TERAPÊUTICO E DA APLICAÇÃO TÓPICA DE HIDROCORTISONA NO TRATAMENTO DO TENDÃO DE RATO EM PROCESSO DE REPARO TECIDUAL.
}

Paulo Umeno Koeke

Dissertação apresentada ao Programa de Pós-Graduação Interunidades Bioengenharia - Escola de Engenharia de São Carlos / Faculdade de Medicina de Ribeirão Preto / Instituto de Química de São Carlos da Universidade de São Paulo, como parte dos requisitos para obtenção do título de Mestre em Bioengenharia.

ORIENTADOR: Prof. Dr. Nivaldo Antonio Parizotto 


\section{AGRADECIMENTOS}

Aos meus pais, irmão e irmã pelo amor, carinho e incentivo.

Ao meu orientador e amigo Nivaldo Parizotto, pelo ensinamento e dedicação.

À Vanessa, pela companhia constante e indispensável.

Aos meus amigos (as) do Laboratório de Eletrotermofototerapia da UFSCar, da Bioengenharia da USP, da Fisioterapia da UFSCar e da República, por auxiliarem na minha formação acadêmica.

Ao Prof. Dr. Benedicto de Campos Vidal do Laboratório de Biologia Celular da UNICAMP, que ensinou e acompanhou às medidas de birrefringência deste trabalho.

Ao Prof. Dr. Oscar Peitl do LAMAV da UFSCar (DeMa), por auxiliar e acreditar fortemente nas pesquisas do Laboratório de Eletrotermofototerapia.

Aos professores Orivaldo Lopes da Silva e Raquel Aparecida Casarotto pela colaboração na finalização deste trabalho.

Ao neRso pela amizade e paciência.

Ao competente coordenador do Programa de Pós-Graduação Interunidades em Bioengenharia, Prof. Dr. José Carlos Pereira.

À eficiente Janete, secretária do Programa de Pós-Graduação Interunidades em Bioengenharia. 


\section{RESUMO}

Estudo Comparativo da Eficácia da Fonoforese, do Ultra-som Terapêutico e da Aplicação Tópica de Hidrocortisona no Tratamento do Tendão de Rato em Processo de Reparo Tecidual. Dissertação de Mestrado, Paulo Umeno Koeke.

A proposta deste estudo foi comparar a eficácia de tratamento da aplicação tópica de hidrocortisona, do ultra-som terapêutico e da fonoforese no processo de reparo do tendão de Aquiles (tendo calcaneus) de ratos, após tenotomia. $O$ grupo controle foi definido como tenotomizados com simulação da aplicação sônica e tendões não tenotomizados. Os dois grupos tratados com ultra-som terapêutico foram no modo pulsado. A irradiação do ultra-som terapêutico foi realizada na freqüência de $1 \mathrm{MHz}$ e uma intensidade de $0.5 \mathrm{~W} / \mathrm{cm}^{2}$ (SATA), por cinco minutos cada sessão. No $13^{\circ}$ dia de pós-operatório, os tendões foram removidos e analisados por meio da microscopia de luz polarizada, com o propósito de investigar e medir a organização das fibras de colágeno, por meio da birrefringência. Os resultados demonstraram que o grupo tratado com a aplicação tópica de hidrocortisona apresentou valores estatísticos similares ao grupo que recebeu simulação sônica, indicando que não houve penetração da hidrocortisona e que as moléculas de colágeno responderam a estimulação ultra-sônica. Tal fato acontece provavelmente originado pelo efeito piezoelétrico que $\mathrm{o}$ ultra-som causa no tecido. $\mathrm{O}$ tratamento com fonoforese demonstrou ser $\mathrm{o}$ método mais eficiente, devido a maior birrefringência, revelando melhor organização e agregação das fibras de colágeno. Esses achados permitem concluir que o ultra-som terapêutico estimula a aceleração do processo de reparo tecidual e induz a penetração transcutânea da hidrocortisona a $10 \%$ numa concentração terapêutica.

Palavras-chave: ultra-som terapêutico, fonoforese, transmissão transcutânea de droga, hidrocortisona, reparo, colágeno, tendão, birrefringência. 


\section{ABSTRACT}

Comparative Study of the Efficacy of Phonophoresis, Therapeutic Ultrasound and Topic Hydrocortisone Application in the Treatment of Rat Tendon in Tissue Repair Process. Master Degree Dissertation. Paulo Umeno Koeke.

The purpose of this study was to compare the treatment efficacy of topic hydrocortisone appliance, therapeutic ultrasound and phonophoresis on the rats' Achilles tendon (tendo calcaneus) repair process after tenotomy. The control group was designed in tenotomized with sham sonic application and non-tenotomized tendons. The two treated groups with therapeutic ultrasound was made in a pulsed mode. The irradiation of therapeutic ultrasound was performed at a frequency of $1 \mathrm{MHz}$ and an intensity of $0.5 \mathrm{~W} / \mathrm{cm}^{2}$ (SATA), for five minutes each session. On the $13^{\text {th }}$ postoperative day, the tendons were removed and analyzed using the polarized light microscopy, with the purpose to detect and measure the organization of collagen fibers through birefringence. The results showed that the treated group with the hydrocortisone topic appliance showed similar statistician values of group that received sham sonic treatment, indicating that not have delivery transdermal and that the molecule of collagen respond to the ultrasonic stimulation. This fact occurs probably by piezoelectric effect originated by ultrasound on the tissue. The teatment with phonophoresis demonstrated being the method more efficient, due the high birefringence, revealing the best organization and aggregation of collagen fibers. These findings allow conclude that the therapeutic ultrasound stimulate the acceleration of tissue repair process and induce the transdermal delivery of hydrocortisone $10 \%$ in a therapeutic concentration.

Keywords: therapeutic ultrasound, phonophoresis, transdermal drug delivery, hydrocortisone, repair, collagen, tendon, birefringence. 


\section{LISTA DE FIGURAS}

FIGURA 1 - llustração conceitual da distribuição de intensidade e do feixe emitido pelo transdutor de ultra-som. .06

FIGURA 2 - Modelo da alfa-hélice da molécula de colágeno ilustrando os átomos de carbono $(\mathrm{C})$, incluindo o $\mathrm{C}$-alfa, outros átomos que compõem a estrutura principal e a conformação de tríplice hélice incluindo os radicais que formam as cadeias laterais. 20

FIGURA 3 - Representação esquemática da tríplice hélice da molécula de colágeno e seu auto-enrolameto organizado. 21

FIGURA 4 - Imagens do tendão de Aquiles do rato liberado e exposto para a realização da tenotomia e da pele suturada, após o procedimento cirúrgico 62

FIGURA 5 - Imagens do contensor de animais contendo aberturas laterais e de um rato contido e submetido à sessão de tratamento com UST. 63

FIGURA 6 - Imagem mostrando o cabeçote com ERA reduzida de $0,5 \mathrm{~cm}^{2}$ utilizado no tratamento. .64

FIGURA 7 - Esquema dos grupos que receberão radiação laser. 64

FIGURA 8 - Distribuições das medições de birrefringência. .70

FIGURA 9 - Distribuições das medições de birrefringência excluindo o Grupo I. .71

FIGURA 10 - Imagens referentes às observações qualitativas da análise de birrefringência total dos tendões, por meio de microscopia de luz polarizada. 
FIGURA 11 - Imagens referentes aos tendões que não sofreram lesão e

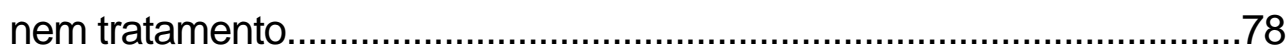

FIGURA 12 - Imagens referentes aos tendões que sofreram lesão e tratamento placebo .79

FIGURA 13 - Imagens referentes aos tendões que sofreram lesão e tratamento com aplicação tópica de hidrocortisona... 80

FIGURA 14 - Imagens referentes ao tendões que sofreram lesão e tratamento com ultra-som terapêutico .81

FIGURA 15 - Imagens referentes aos tendões que sofreram lesão e tratamento com fonoforese. ..82 


\section{LISTA DE TABELAS}

TABELA 1 - Dados observados nos cinco grupos analisados e suas medidas descritivas em relação aos valores de birrefringência. 68

TABELA 2 - Resultados do teste de Kruskal-Wallis para a verificação da diferença entre os grupos estudados. .73

TABELA 3 - Valores dos percentis observados $\left(t_{o b}\right)$ e os correspondentes $p$ valores para a comparação múltipla dos cinco grupos estudados. 83

TABELA 4 - Postos das médias das medições da birrefringência. .147 


\section{LISTA DE ABREVIATURAS E SIGLAS}

$\mu \mathrm{m}$ - micrômetro

ADM - Amplitude de Movimento

AN - Analisador

B - Birrefringência

BF - Birrefringência de Forma

$\mathbf{c m}^{2}$ - centímetro quadrado

DP - Desvio Padrão

EGF - Fator de Crescimento Epidermal

ERA - Área de Radiação Efetiva

et al. - colaboradores

FGF - Fator de Crescimento do Fibroblasto

g - grama

Hz - Hertz

IEC - International Electrotechnical Comission

Kg - quilograma

KHz - Kilo Hertz

mg - miligrama

MHz - Mega Hertz

ml - mililitros

mm - milímetro

ms - mili segundos

NGF - Fator de Crescimento Neural

nm - nanômetro

OR ou $\tau$ - Retardo Óptico

PDGF - Fator de Crescimento Derivado das Plaquetas

PO - Pós-Operatório

POL - Polarizador

RNAm - Ácido Ribonucleico mensageiro

SATA - Média Temporal e Espacial

TGF- $\boldsymbol{\alpha}$ - Fator de Crescimento Transformador

UFSCar - Universidade Federal de São Carlos 
UNICAMP - Universidade Estadual de Campinas

USP - Universidade de São Paulo

UST - Ultra-Som Terapêutico

$\mathrm{W} / \mathrm{cm}^{2}$ - Watts por centímetro quadrado 


\section{LISTA DE SÍMBOLOS}

$\%$ - porcentagem

$\propto-$ alfa

- - graus

$\eta$ - Índice de Refração

$\lambda$ - Lâmbda (comprimento de onda)

${ }^{\circ} \mathbf{C}$ - graus Celsius

$\eta_{E}$ - Índice de Refração na direção do Raio Extraordinário

$\eta_{\circ}$ - Índice de Refração na direção do Raio Ordinário

A - Angstrons

C - Carbono

$\mathrm{CO}_{2}$ - Anidrido Carbônico

$\mathrm{COOH}$ - Carboxila

GI - Grupo Controle Padrão, Sem Lesão e/ou Tratamento

GIl - Grupo Controle, Lesado e Tratamento Placebo

GIII - Grupo Experimental, Tratamento com Aplicação Tópica de Hidrocortisona

GIV - Grupo Experimental, Tratamento com UST na Modalidade Pulsada e Regime de Pulsação de 20\%

GV - Grupo Experimental, Tratamento com Fonoforese na Modalidade Pulsada e Regime de Pulsação de $20 \%$

H - Hidrogênio

N - Nitrogênio

$\mathrm{NH}_{2}$ - Radical Amônia

$\mathrm{O}_{2}$ - Oxigênio

p - valor ou nível de significância 


\section{SUMÁRIO}

RESUMO

ABSTRACT

LISTA DE FIGURAS

LISTA DE TABELAS

LISTA DE ABREVIATURAS E SIGLAS

LISTA DE SÍMBOLOS

I - INTRODUÇÃO

I.1 - ULTRA-SOM TERAPÊUTICO (UST) 01

I.1.1 - FUNDAMENTOS FÍSICOS 01

l.1.1.1 - Som 01

l.1.1.2 - Geração e Propagação das Ondas Ultra-Sônicas 04

I.1.1.3 - Equipamento 05

$\begin{array}{ll}\text { I.1.2-MECANISMOS TERAPÊUTICOS } & 07\end{array}$

I.1.2.1 - Efeitos Mecânicos 08

I.1.2.2 - Efeitos Térmicos 09

I.2 - EFEITOS DO UST SOBRE A PELE

I.3 - FONOFORESE

I.4 - TECIDO CONJUNTIVO DENSO 16

I.5 - COLÁGENO 17

I.6 - TENDÃO 22

I.6.1-ARQUITETURA INTERNA DOS TENDÕES

I.7-TENDÃO DO CALCÂNEO 24

I.7.1-RUPTURA DO TENDÃO DO CALCÂNEO

I.8-PROCESSO DE REPARO TECIDUAL

I.8.1 - FASE INFLAMATÓRIA 28

I.8.2 - FASE NEOANGIOGÉNICA E PROLIFERATIVA 32

I.8.3-FASE DE REMODELAMENTO 36

I.8.4-CICATRIZACÃO INTRÍNSICA E EXTRÍNSICA DO TENDÃO 38

I.8.5-CICATRIZACÃO INTRÍNSICA 39

1.8.6-CICATRIZACÃO EXTRÍNSICA

I.8.7- CICATRIZACÃO INTRÍNSICA E EXTRÍNSICA

I.9 - EFEITOS DO UST SOBRE O REPARO TECIDUAL

I.10 - MICROSCOPIA DE POLARIZAÇÃO

I.11 - PROPRIEDADES ANISOTRÓPICAS ÓPTICAS 52

I.11.1-BIRREFRINGÊNCIA DE MATERIAIS

II - OBJETIVO 57

III - MATERIAIS E MÉTODOS 58

III.1 - ANIMAIS DE EXPERIMENTAÇÃO 58

III.2 - AGRUPAMENTO 58

III.3 - O APARELHO DE UST 61

III.4 - MODELO EXPERIMENTAL 61

III.5 - PROCEDIMENTO CIRÚRGICO 61

III.6 - PROCEDIMENTO EXPERIMENTAL 62 
III.7 - SACRIFÍCIO DOS ANIMAIS 65

III.8 - PREPARAÇÃO DAS LÂMINAS HISTOLÓGICAS

III.9 - MEDIDAS DE BIRREFRINGENNCIA 66

III.10 - ANÁLISE ESTATÍSTICA 67

III.10.1 - ANÁLISE DESCRITIVA

III.10.2 - COMPARACÃO ESTATÍSTICA ENTRE OS 5 GRUPOS 72

ESTUDADOS

IV - RESULTADOS

IV.1 - ANÁLISE QUALITATIVA

IV.2 - ANÁLISE QUANTITATIVA 83

IV.2.1 - COMPARACÃO MÚLTIPLA DOS CINCO GRUPOS

ESTUDADOS

V-DISCUSSÃO

V.1 - DA METODOLOGIA

V.2 - DOS RESULTADOS 99

VI - CONCLUSÃO 112

VII - REFERÊNCIAS BIBLIOGRÁFICAS 114

$\begin{array}{ll}\text { VIII - ANEXOS } & 145\end{array}$ 


\section{INTRODUÇÃO}

\section{I.1 ULTRA-SOM TERAPÊUTICO (UST)}

\section{I.1.1 FUNDAMENTOS FÍSICOS}

\section{I.1.1.1 Som}

Acústica é a porção da Física que estuda a geração, propagação e detecção das ondas acústicas ou mecânicas, às quais podemos associar o conceito de som.

Ondas mecânicas são as que se propagam em meios deformáveis ou elásticos. Elas surgem de uma perturbação numa região de um meio elástico. Tendo o meio propriedades elásticas, a perturbação é transmitida para as partículas adjacentes, a qual irá vibrar e transferir, novamente, parte da energia para outra partícula, e assim sucessivamente até o término da energia.

A onda mecânica propaga-se no ar como onda longitudinal, ocorrendo o mesmo em meios cujas moléculas ou átomos estão fracamente interligados (como nos gases e líquidos), podendo se propagar como onda transversal nos meios de alta coesão molecular (como nos sólidos) e deixar de existir no vácuo.

Segundo CREPON (1996) e BISSCHOP et al. (2001), a vibração é um tipo rápido de movimento oscilatório em torno de uma posição de equilíbrio. Ela emite ondas mecânicas caracterizadas por sucessões de pressões e rarefações de moléculas no meio em que se propagam, engloba ondas 
mecânicas longitudinais transmitidas a um determinado meio e propagação retilínea.

São definidas por sua amplitude, expressa em milímetros ou micrômetros e pela freqüência (número de pressão - rarefação por segundo), expressa em hertz (BISSCHOP et al., 2001).

Sua classificação é feita em função do ponto auditivo do homem, escalonado entre $20 \mathrm{~Hz}$ e $20.000 \mathrm{~Hz}$ (freqüências abaixo de $17 \mathrm{~Hz}$ são denominadas "infra-som" e acima de $17000 \mathrm{~Hz}$, "ultra-som") ou de acordo com seu uso terapêutico (abaixo de $1000 \mathrm{~Hz}$, vibração de baixa freqüência e acima de $500 \mathrm{KHz}$, ultra-som). Observe que, só neste intervalo de freqüências, as terminações nervosas no nosso ouvido interno entram em ressonância com a onda mecânica, gerando pulsos elétricos que produzem em nosso cérebro a percepção sonora. Portanto é incapaz de detectar sons com freqüências muito baixas (infra-sons) ou sons com freqüências muito altas (ultra-sons) (STARKEY, 1999).

Escala auditiva do Homem (BISSCHOP et al, 2001):

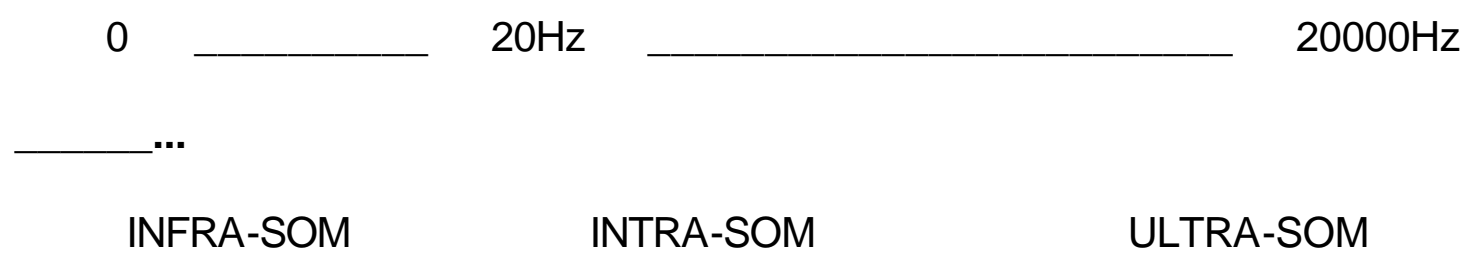

Escala terapêutica (BISSCHOP et al, 2001):

1

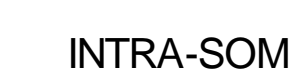
$1000 \mathrm{~Hz} \quad 500 \mathrm{KHz}$ ULTRA-SOM

(Vibrações de baixa freqüência) 
Ao entrar em contato com determinado meio, as vibrações podem sofrer diferentes comportamentos em relação à sua propagação. Podem penetrar no meio e serem retidas, produzindo calor (fenômeno da absorção). Pode ocorrer mudança na direção das ondas mecânicas quando atingem uma superfície a um determinado ângulo e com certa freqüência e são devolvidas para outra direção. Nesses casos, se o emissor de onda permanecer fixo, uma onda estacionária é firmada, em que a soma de seu trajeto incide com a onda refletida. Esse fato mostra o crescimento das pressões e rarefações e resultando em potências muito superiores à original (fenômeno da reflexão). As ondas podem, ainda, sofrer desvio de sua trajetória ao atravessar a superfície de separação de dois meios nos quais as velocidades de propagação diferem de um meio para outro (refração) ou sofre desvio sobre sua propagação quando reencontram um obstáculo (difração).

Também tem o fenômeno da ressonância, que surge quando um corpo é submetido a vibrações de amplitude constante, nas quais variamos progressivamente a freqüência, constatou-se que para determinada freqüência, o corpo começa a vibrar com amplitude visivelmente maior (CREPON, 1996).

As vibrações de baixa freqüência são geradas por pressões ritmadas manuais ou piezoterapia (BISSCHOP et al., 2001).

O UST é um movimento ondulatório na forma de onda mecânica de alta freqüência que transmite energia através da vibração das partículas do meio (TER HAAR, 1987). 


\section{I.1.1.2 Geração e Propagação das Ondas Ultra-Sônicas}

Qualquer material vibrante pode servir como fonte de ultra-som. Como exemplo disto são os materiais ou cristais piezoelétricos. Nestes tipos de materiais podem ocorrer o fenômeno da piezoeletricidade quando aplicamos pressão mecânica sobre ele, desenvolvendo cargas elétricas na sua superfície. Os cristais piezoelétricos (ou cerâmicas) produzem cargas elétricas positivas ou negativas quando se contraem ou expandem. Tal efeito é reversível, isto é, quando aplicamos uma corrente elétrica alternada sobre estes materiais, eles são capazes de vibrar e, portanto de emitir ondas ultra-sônicas. O UST é produzido pelo efeito piezoelétrico inverso. A vibração nestes materiais resulta na produção de ondas mecânicas de alta frequência (HOOGLAND, 1986; STARKEY, 1999).

Portanto, as ondas ultra-sônicas são produzidas por uma corrente alternada apropriada seguindo através de um cristal piezoelétrico dentro de um transdutor (sistema fechado com material ou cristal cerâmico polarizado, o qual deve possuir elevada atividade piezoelétrica).

Modernamente utiliza-se o cristal de PZT cerâmico (composto por Chumbo, Zircônio e Titânio) que possui elevada atividade piezoelétrica e tem como manter suas características em temperaturas relativamente elevadas (CREPON, 1996).

As ondas do UST propagam-se longitudinalmente (a direção da vibração é a mesma da propagação) e transversalmente (a direção do movimento das moléculas é perpendicular a direção da propagação). Ondas longitudinais têm 
como característica causar pontos de compressão, onde temos aumento na concentração das partículas e expansão, onde se observa aumento da distância das partículas (rarefação) (ZISKIN et al., 1999). Ondas transversais são amortecidas de maneira extremamente rápida em líquidos e tecidos moles.

É possível a ocorrência de ondas estacionárias. Neste caso, duas ou mais ondas podem combinar-se formando uma nova onda. Este tipo de onda é fruto da interação entre onda refletida e a onda incidente, o que gera áreas de alta densidade num ponto específico do tecido.

\section{I.1.1.3 Equipamento}

As instrumentações disponíveis para UST são constituídas por duas partes: um circuito elétrico e um transdutor. O circuito elétrico converte a tensão da rede em corrente alternada. O transdutor recebe esta voltagem de corrente alternada que tem a mesma freqüência de ressonância do cristal. Deste modo, a energia elétrica é convertida em energia mecânica.

O transdutor é um dispositivo montado a partir de cerâmicas ou cristais piezoelétricos que geram ondas sônicas na freqüência determinada pelo material, as quais se propagam através dos tecidos do corpo humano e produzem efeitos terapêuticos por vibração no tecido, principalmente em nível molecular (ALLEN \& BATTYE, 1978; HOOGLAND, 1986; ZISKIN et al., 1999).

O transdutor do UST emite um progressivo campo de ondas ultrasônicas. Há neste campo uma zona (o campo próximo) onde o tamanho do feixe permanece relativamente constante, entretanto existe algumas variações da intensidade dentro desta zona. Esta zona é seguida por uma zona onde o 
feixe diverge e torna-se mais uniforme (o campo distante). A FIGURA 1 ilustra o campo próximo com a transição para o campo distante.

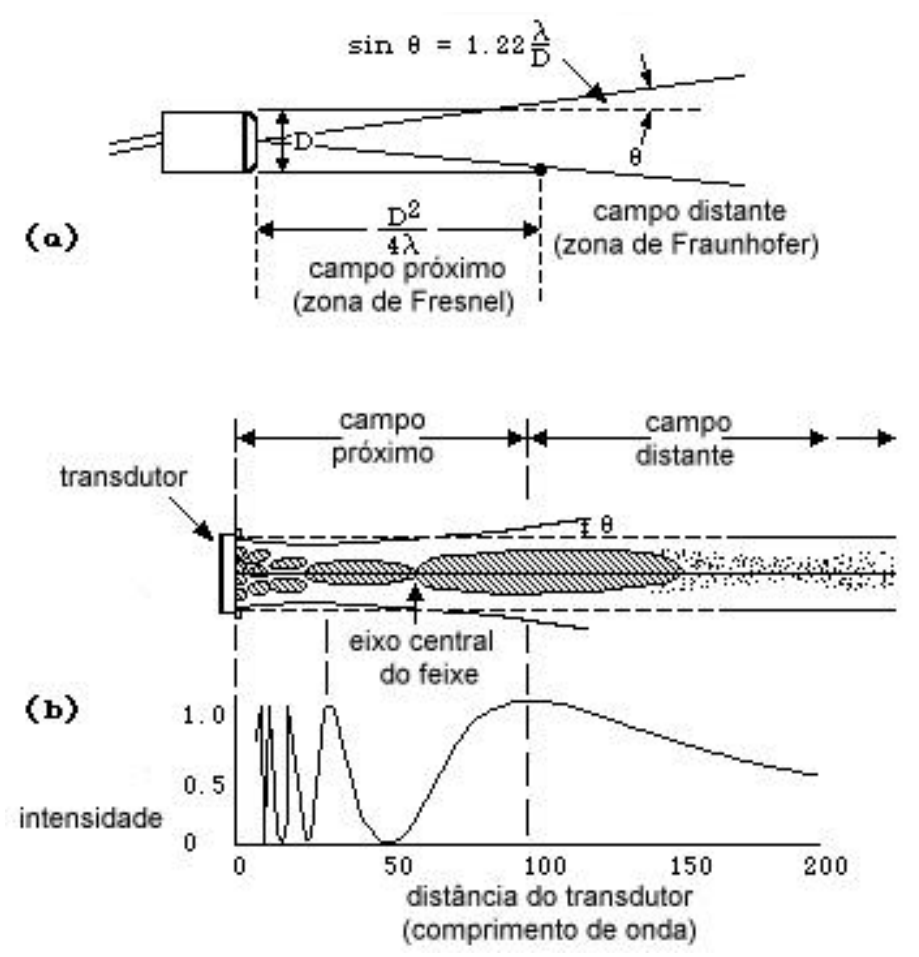

FIGURA 1 - llustração conceitual da distribuição de intensidade e do feixe emitido pelo transdutor de ultra-som. Modelo modificado de Wells, 1977.

A área de radiação efetiva (conhecido como ERA) é relativamente menor que a área do transdutor que estará em contato com a pele (HOOGLAND, 1986).

A freqüência com que o transdutor irá vibrar é a mesma da oscilação das cargas elétricas da corrente. Os equipamentos no Brasil operam na freqüência de $1 \mathrm{MHz}$ e $3 \mathrm{MHz}$. Já está bem estabelecido na literatura que quanto maior a freqüência da onda ultra-sônica, menor será sua penetração nos tecidos e maior a absorção (MAXWELL, 1992; STARKEY, 1999; ZISKIN et al., 1999).

Os circuitos de equipamentos de UST permitem o controle da amplitude da corrente elétrica fornecida ao transdutor. Modificações na amplitude da corrente repercutirão na magnitude das vibrações mecânicas do cristal e 
conseqüentemente na intensidade de força das ondas sonoras. Esta intensidade é a potência (medida em Watts) por centímetro quadrado da Área de Radiação Efetiva (ERA) do cabeçote $-\mathrm{W} / \mathrm{cm}^{2}$.

Os geradores ultra-sônicos são capazes de emitir energia em duas modalidades, contínuo e pulsado. No modo pulsado, o circuito do aparelho faz chaveamento (liga/desliga) da corrente elétrica, criando pacotes de energia ou pulsos. O ciclo útil mais usado é no modo pulsado 1:4 (2 ms on e $8 \mathrm{~ms}$ off ou pulsado a 20\%). No UST contínuo, a intensidade da onda permanece constante durante todo o tratamento (WILLIANS, 1987).

\subsubsection{MECANISMOS TERAPÊUTICOS}

Os mecanismos físicos pelos quais o UST induz respostas fisiológicas são classificados como térmicos e mecânicos.

O UST pulsado pode apresentar somente os efeitos não térmicos (apenas mecânico) no tecido ou apresentar o efeito térmico diminuído. Várias das ações da aplicação do UST são devido a interação entre efeitos térmicos e não térmicos (ZISKIN et al., 1999).

\section{I.1.2.1 Efeitos Mecânicos}

É de natureza mecânica o primeiro efeito provocado da interação do UST com o tecido biológico.

Os efeitos não térmicos incluem a cavitação, microvibrações e correntes acústicas (DYSON, 1982). 
Cavitação é a formação e o crescimento de cavidades ou bolhas de ar, ou vapor, em um meio. Esse fenômeno pode ser resultado de mudanças de pressão ultra-sonicamente induzidas (COAKLEY, 1978).

Podem ser observados dois tipos de cavitação, a estável e a transiente.

$\mathrm{Na}$ cavitação estável, as bolhas crescem pouco ou moderadamente durante cada ciclo acústico, podendo, ao atingir um determinado tamanho, relacionado com a freqüência sonora empregada, entrarem em ressonância, resultando em microvibrações, porém num estado estável, permanecendo intactas.

$\mathrm{Na}$ cavitação transiente, núcleos de gases crescem subitamente no meio, sob influência das altas intensidades que causam uma grande variação da pressão acústica, e acabam por colapsar violentamente resultando em lesões teciduais (FERRARI,1987; TER HAAR, 1987; STARKEY,1999).

Lehmann (1965), utilizando um ultra-som contínuo de $1 \mathrm{MHz}$, observou que a partir da intensidade de $1 \mathrm{~W} / \mathrm{cm}^{2}$ ocorre a cavitação transiente.

No entanto, isso também pode ser gerado nos fluídos se as condições de irradiação permitirem a formação de ondas estacionárias, como resultado da sobreposição das ondas incidentes e refletidas.

Segundo TER HAAR (1987) a movimentação contínua do cabeçote do UST durante a irradiação do tecido biológico evitaria a formação das ondas estacionárias.

De acordo com LOW \& REED (2001), as células endoteliais podem ser lesadas pela formação de ondas estacionárias, ocorrendo a formação de trombose. 
As correntes acústicas são o resultado da cavitação estável e produzem uma constante circulação de fluidos localizada ao redor das bolhas e conseqüentemente, adjacente às membranas celulares e suas organelas. Este fluxo líquido tem valor terapêutico uma vez que causa mudanças na permeabilidade da membrana e assim facilita a passagem de cálcio, potássio e outros metabólitos para dentro ou para fora das células (KITHEN \& PARTRIDGE, 1990).

Segundo STARKEY (1999), dependendo do tipo de célula, a alteração iônica produzida pode desenvolver alterações na síntese e secreção celular, como por exemplo, a síntese de colágeno, com secreção de fatores quimiotáticos e aumento da atividade fibroblástica durante o processo de cicatrização tecidual.

\section{I.1.2.2 Efeitos Térmicos}

A micromassagem dos tecidos, devido ao efeito mecânico (vibrações sônicas) que o UST provoca, gera calor por fricção (HOOGLAND, 1986).

Segundo LEHMANN \& DE LATEUR (1994), para se atingir um efeito terapêutico útil através do aquecimento, a temperatura tecidual precisa ser mantida entre $40^{\circ} \mathrm{C}$ e $45^{\circ} \mathrm{C}$ por pelo menos 5 minutos.

A quantidade de aquecimento local que pode ser alcançado por uma fonte ultra-sônica, deve-se à absorção de parte da energia mecânica pelos tecidos que são atravessados pelas ondas e aos pontos de reflexão das ondas, os quais ocorrem, sobretudo nos limites entre os tecidos com distinta impedância acústica específica. A quantidade de energia absorvida por um 
determinado tecido é relativo ao coeficiente de absorção do tecido (HOOGLAND, 1986, STARKEY, 1999).

A respeito das respostas fisiológicas induzidas pelo UST, a escola Americana defende a linha que preconiza os efeitos térmicos. No sentido de elevar a temperatura tecidual aos valores terapêuticos mencionados, os autores americanos recomendam altas intensidades. Para LEHMANN \& DE LATEUR (1994), as intensidades úteis para terapia variam entre $0,5 \mathrm{~W} / \mathrm{cm}^{2} \mathrm{e}$ 4.0 W/cm ${ }^{2}$.

Ao contrário, a escola Européia, se interessa mais pelas baixas intensidades e pelos tratamentos utilizando as modalidades pulsadas.

\section{I.2 EFEITOS DO UST SOBRE A PELE}

Segundo MITRAGOTRI et al. (1995a, b) a camada córnea, considerada a mais externa da pele humana, possui cerca de $15 \mu \mathrm{m}$ de espessura, é formada de queratinócitos cercadas por camadas lipídicas, é uma camada que possui uma baixa permeabilidade, visto que, a estrutura é altamente ordenada pelos queratinócitos e pelas suas camadas lipídicas. Os queratinócitos são células sem núcleo, achatadas, mortas; com citoplasma farto de uma escleroproteína birrefringente e filamentosa, denomida de queratina (JUNQUEIRA \& CARNEIRO, 1990).

Através de uma análise de microscopia de fluorescência WU et al. (1998) verificou que as ondas sonoras emitidas pelo ultra-som de $168 \mathrm{KHz}$ com intensidade de $1,2 \mathrm{~W} / \mathrm{cm}^{2}$ causou uma modificação estrutural significativa na camada córnea de cadáveres humanos. O aspecto dos queratinócitos antes de sofrerem a irradiação sônica era normal, ou seja, organizadas em hexagonal. 
Já após 15 minutos de ultra-som, ocorreu um desarranjo. Portanto, a resultante deste trabalho experimental corrobora com a hipótese de que o ultra-som provoca uma mudança no arranjo dos queratinócitos da camada córnea da pele. Há também a presença de bolsas de ar com cerca de $20 \mu \mathrm{m}$ de dimensão nas moléculas lipídicas, os quais seriam responsáveis em aumentar a permeabilidade. Considerando que a estrutura altamente organizada, das camadas dos queratinócitos e dos lipídios, seria o fator de impermeabilidade da pele aos fármacos. Sendo assim, o efeito de cavitação do ultra-som seria a melhor explicação para a efetividade da fonoforese.

De acordo com FRENKEL et al. (1999) o efeito de cavitação do ultrasom é devido à intensidade e ao tempo de aplicação e que as altas intensidades geram morte celular.

\section{I.3 FONOFORESE}

Há mais de 60 anos vem sendo utilizado o ultra-som como agente terapêutico. O ultra-som terapêutico é uma modalidade usada em fisioterapia no tratamento de uma variedade de situações, incluindo lesões de tecidos moles e inflamação, distúrbios circulatórios e estimulação de reparação de tecidos.

Medicamentos antiinflamatórios não hormonais também são freqüentemente receitados nessas condições e tradicionalmente têm sido tomados oralmente na forma de comprimidos ou cápsulas. Porém, devido à natureza irritante desse medicamento no sistema gastro-intestinal, pesquisadores estudam outras maneiras de aplicação desses medicamentos. 
O uso tópico de antiinflamatórios não hormonais em forma de pomada, creme e gel tem sido indicados no alívio de inflamações dos tecidos.

Além disso, alguns autores têm demonstrado que o ultra-som pode aumentar a penetração em relação à quantidade e profundidade de algumas drogas através da pele. Este novo conceito do ultra-som terapêutico combinado com drogas tem promovido investigações nos diversos campos da medicina. Segundo TACHIBANA \& TACHIBANA (1999), a energia ultra-sônica pode aumentar o efeito de agentes trombolíticos, insulina e até para tratamentos de câncer (recentemente denominado de "Sonodynamic Therapy"). Vários exemplos da aplicação do ultra-som que estão sobre investigação podem no futuro revolucionar o sistema de transferência de droga.

O primeiro relato da literatura sobre a atuação clínica utilizando a técnica de inserir um antiinflamatório através de um ultra-som terapêutico, técnica chamada de fonoforese, foi descrito por FELLINGNER \& SCHMID (1954), sendo o agente de acoplamento a hidrocortisona, em tratamento de poliartrite dos dedos da mão. Desde então, foi realizada uma série de estudos e pesquisas sobre fonoforese, tentando esclarecer as melhores formas de uso dessa técnica.

O efeito de deposição de droga pelo ultra-som é certamente um tipo de aplicação clínica que vem ganhando crença. No entanto, até os dias de hoje ainda não se tem parâmetros exatos, quantificados na literatura, que possibilitem descrever a sua prática baseada em evidências. Pensando nisso, PARIZZOTO et al., (2003), em sua meta-análise, sugerem que as pesquisas sobre o uso da fonoforese para tratamento de desordens musculo-esqueléticas apresentem os critérios propostos, a fim de que os trabalhos apresentem maior 
confiabilidade, e que se possa, com o tempo, determinar parâmetros exatos para utilização dessa técnica.

Vários mecanismos têm sido sugeridos para explicar o aumento da penetração das drogas pela fonoforese (FANG et al., 1999), entre eles o aumento da temperatura, cavitação, bem como pressão de radiação (TYLE \& AGRAWALA, 1989).

Acredita-se que a principal circunstância que envolve a deposição da droga é o fenômeno da cavitação que resulta na formação de microbolhas gasosas na camada externa da pele (estrato córneo) que podem romper-se violentamente, e possivelmente permitir a passagem da droga (FANG et al., 1999; MILLER, 2000; UEDA, 1996a, b). Considerando este fato, é possível que uma desorganização da região lipídica da camada córnea venha a ocorrer (FANG et al., 1999, UEDA, 1996a, b; MITRAGOTRI et al., 1995a, b) podendo aumentar a sua permeabilidade. Alguns experimentos têm auxiliado a possibilidade de ocorrer a cavitação na camada córnea (MITRAGOTRI et al., 1995a, b), mas esse fenômeno nunca tinha sido demonstrado. Em outro estudo, foi observada uma grande fenda no espaço intercelular na camada córnea nas condições de ultra-som $15 \mathrm{MHz}$ e $0,1 \mathrm{~W} / \mathrm{cm}^{2}$. Embora a interpretação de tais buracos continue incerta, eles podem ser conseqüência da cavitação. A cavitação começa a aumentar com a freqüência do ultra-som e esta é fortemente demonstrada em células suspensas dentro de líquidos.

Diversos estudos vêm sendo feitos com várias drogas TYLE \& AGRAWALA (1989), usando diferentes dispositivos e condições de ultra-som em termos de intensidade, freqüência (BOMMANNAN et al., 1992; MITRAGOTRI et al., 1995a, b), duração e modo contínuo e pulsado. 
No procedimento da fonoforese tem sido encontrado um moderado, mas não um completo sucesso.

O conceito é simples e envolve a aplicação tópica da droga através da camada externa da pele (estrato córneo) dirigida pelo ultra-som para o tecido subjacente.

Alguns resultados conflitantes têm sido publicados no decorrer dos anos. Apesar de pesquisas relatarem um efeito positivo do ultra-som, em várias publicações, há algumas inconsistências na literatura para a intensificação da permeabilidade da droga na pele: aproximadamente $75 \%$ dos estudos relatam o efeito da fonoforese, enquanto que outros obtiveram resultados negativos (BYL, 1995).

GRIFFIN \& TOUCHSTONE (1968), em estudos experimentais com a utilização de hidrocortisona na pele de porcos, relataram um aumento dos níveis de cortisol em músculo e nervo. Eles concluíram que o aumento da potência do ultra-som, tempo de aplicação e concentração da droga, aumenta a penetração de hidrocortisona. Embora esses estudos tentem identificar diretrizes de tratamento para fonoforese, a análise dos dados e metodologia limita aplicação destes resultados. Esses autores melhoraram o efeito da penetração de hidrocortisona, porém queimaram os animais, portanto estes resultados não podem ter aplicação clínica.

NOVAK (1964) referiu a transmissão de lidocaína dentro de músculos de ratos.

FARRELL et al. (1998), não observaram diferenças estatísticas significantes no aumento do manitol através de pele de porcos in vitro. 
GRIFFIN et al. (1967) relatou que os pacientes tratados com fonoforese de hidrocortisona tiveram uma redução da dor de $68 \%$ e aumento da amplitude de movimento quando comparada com o controle. Neste trabalho não foram avaliados os efeitos da aplicação tópica sozinha de hidrocortisona, e com isso foi impossível comparar a aplicação desta droga com a fonoforese.

KLEINKORT \& WOOD (1975) realizaram um estudo retrospectivo tratando uma variedade de condições inflamatórias e comparam os resultados dos tratamentos usando uma preparação de $1 \%$ e outra de $10 \%$ de hidrocortisona e concluíram que $10 \%$ é mais efetivo.

McELNAY et al. (1985) estudou o aumento da penetração transdermal de anestésicos e antiinflamatórios não-hormonais que não foram intensificados pelo ultra-som. Os autores sugerem que o efeito negativo pode ser atribuído ao fármaco usado.

Como o ultra-som vem sendo amplamente usado na fisioterapia, associado com vários agentes antiinflamatórios, alguns autores discutem a eficácia da fonoforese, assim como dos próprios efeitos do ultra-som (GAM \& JOHANNSEN, 1995; VAN DER WINDT et al. 1999; ROBERTSON \& BAKER, 2001) e sugerem estudos mais controlados. O principal motivo é que os tratamentos realizados em pesquisas não fornecem bases quantitativas, apenas subjetivas.

MITRAGOTRI et al. (1997) tem sumarizado uma ampla quantia de literatura nesta área, estudos com diferentes drogas onde não havia deposição na pele induzida pelo ultra-som e estudos na qual havia. 


\section{I.4 TECIDO CONJUNTIVO DENSO}

O chamado tecido conjuntivo denso é composto por células (fibroblastos, macrófagos e mastócitos); fibras (colágeno e elastina) e substância de sustentação (glicosaminoglicanas, proteoglicanas e glicoproteínas) (TILLMAN \& CUMMINGS, 1992a, b).

No tecido conjuntivo denso, o comportamento mecânico como resistência à compressão, tensão, extensibilidade e torção, são influenciados pelas propriedades físicas do colágeno e outras fibras; organização da arquitetura das fibras; tipo de fibras de colágeno; proporção de colágeno e outras fibras; maturidade de fibras de colágeno; orientação das fibrilas; diâmetro e comprimento dessas fibrilas e quantidade, tipo, arranjo e hidratação das substância de sustentação (CULAW et al., 1999; BIRK et al., 1997; TILLMAN \& CUMMINGS,1992a, b).

Variações no tipo e na concentração das macromoléculas da matriz extracelular podem determinar suas características funcionais. Além disso, a orientação das fibras tem uma importante função nas propriedades mecânicas dos tecidos, como também no estado de agregação ordenada do colágeno (VIDAL \& CARVALHO, 1990).

Tecidos com grande quantidade de proteoglicanas combinado com uma rede de fibras colágenas resistem à compressão. Para resistir às forças tensivas, é necessário um alto conteúdo de fibras colágenas e baixa quantidade de proteoglicanas. 
Segundo CULAW et al. (1999) patologias ou traumas podem modificar a morfologia normal do tecido conjuntivo levando a alterações biomecânicas importantes.

\section{I.5 COLÁGENO}

De acordo com JUNQUEIRA \& CARNEIRO (1990) a quantidade de fibras colágenas predomina no tecido conjuntivo. As fibras colágenas são formadas por uma glicoproteína estrutural denominada colágeno, o qual tem uma composição própria de aminoácidos.

O colágeno é uma proteína que corresponde a $30 \%$ do peso corporal do homem (MAYNE, 1984). Segundo CULAW et al. (1999) e PARIZOTTO (1998) o colágeno compõe a matriz extracelular dos animais multicelulares, com cerca de 19 tipos distintos de colágeno, todos com características individuais que determinam as funções específicas dos diferentes tecidos.

Todas as moléculas de colágeno são longas; constituídas de uma tríplice hélice de três cadeias de polipeptídeos chamadas de cadeias alfa. Os colágenos se destinguem uns dos outros por suas cadeias de polipeptídeos, propriedades físicas, morfologia, distribuição nos tecidos e funções. O colágeno tipo I constitui $90 \%$ do total de colágeno do corpo dos mamíferos e é encontrado com maior freqüência em estruturas como tendões, ligamentos, cápsula dos órgãos, derme, matriz para reforço do esqueleto (associado aos minerais como ossos e dentina), entre outros tecidos especiais que devem ser fortes ou ter propriedades incomuns (MIMNI \& HARKNESS, 1988). Este tipo de colágeno possui alta força tênsil com elasticidade limitada, além de boa 
capacidade para a transmissão de forças (CULAW et al., 1999; JÓZSA \& KANNUS, 1997; PARKINSON et al., 1997; BIRK et al., 1989; MIMNI \& HARKNESS, 1988).

Para o tendão, o colágeno oferece uma grande força tênsil, enquanto que a substância fundamental promove suporte para as fibras de colágeno regulando a estruturação extracelular das moléculas de procolágeno (KHAN et al., 1999).

Os fibroblastos são os principais responsáveis pela síntese de colágeno tipo I. Contudo, outras células como os mastócitos, os macrófagos e algumas células indiferenciadas originadas do tendão, epitendão e paratendão podem sintetizá-lo (CHAN et al., 1997; JÓZSA \& KANNUS, 1997).

A forma dos fibroblastos é normalmente estrelada com poucas protuberâncias citoplasmáticas correndo entre os feixes de colágeno adjacentes (ENWEMEKA, 1989a).

Em seu estado quiescente, os fibroblastos consistem de um núcleo proeminente envolvido por uma fina camada de citoplasma; é um fino cordão que pode projetar-se para dentro da matriz. Em situações de desenvolvimento ou reparo tendinoso, diferença metabólica aparece devido seu potencial celular e a estrutura subcelular reflete seu estado metabólico (ENWEMEKA \& SPIELHOLZ, 1992).

É o conjunto de eventos, intracelular e extracelular, que determinam o controle da biosíntese do colágeno. Além de colágeno, o fibroblasto produz outros componentes da matriz extracelular (BIRK \& TRELSTAD, 1986).

De acordo com TILLMAN \& CUMMINGS (1992a), a formação do colágeno envolve a transcrição e a translação de genes similares a produção 
de outras proteínas, as cadeias alfas são sintetizadas no retículo endoplasmático rugoso dos fibroblastos, pela tradução de um RNAm, forma-se a molécula de colágeno (estrutura composta por 3 cadeias de polipeptídeos enroladas em espiral formando uma tríplice hélice).

A síntese de cada cadeia longa de polipeptídeo ocorre com dois peptídeos de registro em cada extremidade, os quais terminam o alinhamento das cadeias protéicas em grupos de três, facilitando a combinação, afim de formar a molécula de colágeno (CULAW et al., 1999; SANTANDER, 1999; MIMNI \& HARKNESS, 1988).

A característica peculiar do colágeno é a sua composição de aminoácidos; a cada três aminoácidos o terceiro é sempre glicina; a prolina e a hidroxiprolina aparecem em $20 \%$ dos aminoácidos da cadeia de colágeno (CULAW et al., 1999). Cada uma das cadeias de colágeno tem um total de $3.000 \AA$ ou $300 \mathrm{~nm}$ e uma largura de $14 \AA$ ou $1,4 \mathrm{~nm}$.

O colágeno nativo é um cristal orgânico de comprimento e largura uniformes, que quando transportado para as membranas das células e estruturados no espaço intersticial, seus componentes peptídicos são removidos e a molécula leve e diminuída, sofre extrusão celular. Sem mudança na formação interna da molécula, esta permanece como cristal orgânico (TILLMAN \& CUMMINGS, 1992a).

Nas duas extremidades da tríplice hélice estendem-se porções de cadeias peptídicas que não estão formando o tripléx, os telopeptídeos C (carbono) de $(\mathrm{COOH})$ e $\mathrm{N}$ (nitrogênio) de $\left(\mathrm{NH}_{2}\right)$, as quais são responsáveis pela agregação lateral das moléculas de colágeno (VIDAL, 1987a). 
No colágeno tipo I, a tríplice hélice está constituída por duas cadeias $\alpha$ (alfa) iguais, denominadas $\alpha_{1}$ (alfa), e uma cadeia $\alpha_{2}$ diferentes das demais em sua composição. As cadeias peptídicas se enrolam em hélice e são unidas entre si através de pontes de hidrogênio (VIDAL, 1987a). Pode-se representar o colágeno I pela fórmula: $\left[\propto_{1}(\mathrm{I})\right]_{2} \propto_{2}$.
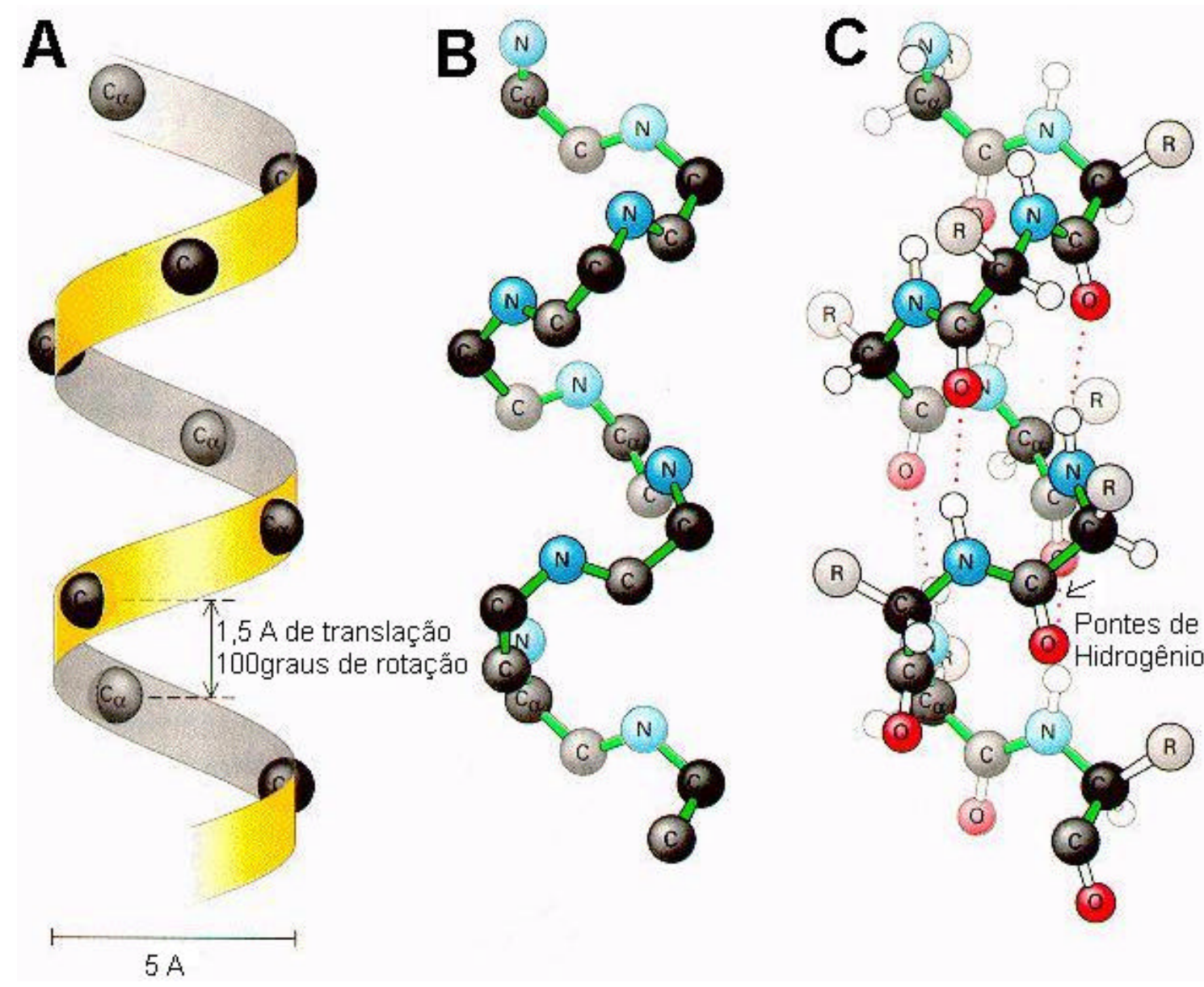

FIGURA 2 - Em A temos um modelo da alfa-hélice da molécula de colágeno ilustrando os átomos de carbono (C), incluindo o Galfa. Observar as medidas de translação e rotação. Em B temos um modelo da alfa-hélice da molécula de colágeno com inclusão dos outros átomos que compõem a estrutura principal. Em C está representada a molécula de colágeno, evidenciando a conformação de tríplice hélice incluindo os radicais que formam as cadeias laterais. Notar as ligações intermoleculares por meio de pontes de hidrogênio $(H)$. Modelo modificado de K. Okuyama; K. Okuyama, S. Arnott, M. Takayanagi, e M. Kakudo. J. Mol. Biol, v. 152, p. 427, 1981. 

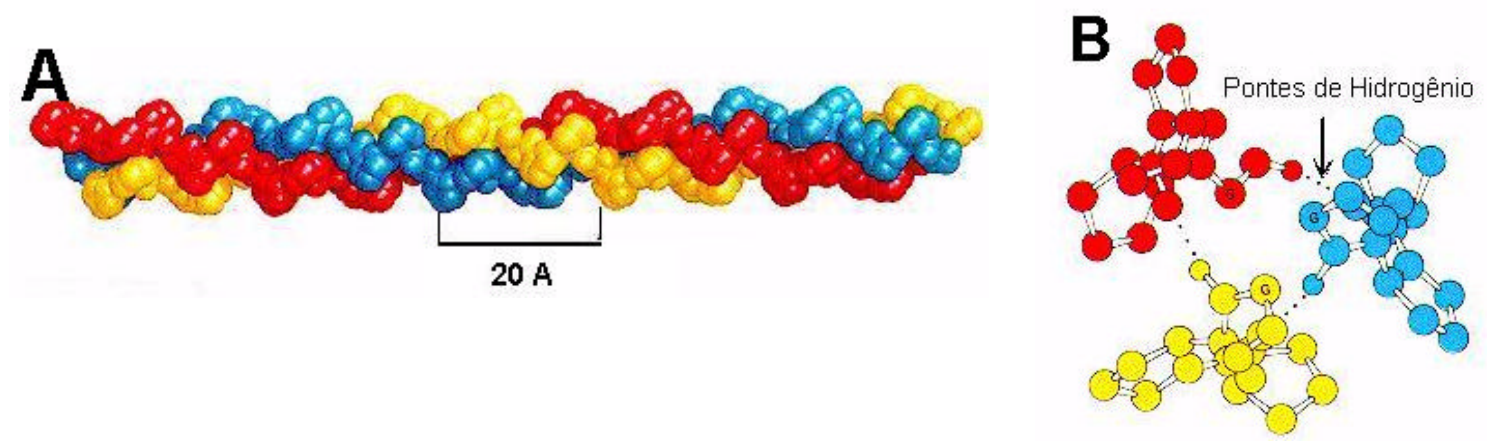

FIGURA 3 - Em A temos a representação esquemática da tríplice hélice da molécula de colágeno e seu auto-enrolameto organizado. A conformação estrutural é resultado das forças intra e inter-moleculares. A figura B representa um corte transversal do esquema $A$ localizando as ligações intra-moleculares realizadas por intermédio das pontes de hidrogênio. Modelo modificado de K. Okuyama; K. Okuyama, S. Arnott, M. Takayanagi, e M. Kakudo. J. Mol. Biol, v. 152, p. $427,1981$.

Segundo JÓZSA \& KANNUS (1997) e TILLMAN \& CUMMINGS (1992a) próximo à superfície dos fibroblastos, dentro do espaço extracelular, as moléculas de colágeno são secretadas. Para cada conjunto de cinco moléculas de colágeno há uma compactação para a formação da menor unidade de organização da fibra de colágeno; a microfibrila. A próxima unidade da organização é a subfibrila, que agrupadas constituirão as fibrilas.

Esta hierarquia reflete a alta organização da estrutura molecular do colágeno.

VIDAL (1995b), relata que a importância do auto-arranjo molecular transcende este amplo espectro biológico do campo da síntese da nanoestrutura do tendão. $\mathrm{O}$ auto-arranjo permanece e as fibras de colágeno formam feixes orientados em grupos, paralelos ao eixo longitudinal do tendão, entretanto exibe vários graus de inclinação com relação ao eixo principal do colágeno, demonstrando uma distribuição helicoidal desta estrutura. Estes estudos reafirmam os achados de uma estrutura fibrilar encontrada nos estudos de VIDAL (1995a), onde o autor comprova a existência da estrutura 
ondulatória ou crimp (organização estrutural com variação de orientação periódica) como sendo parte da estrutura helicoidal das fibras de colágeno.

De acordo com VIDAL (1994), as forças que agem sobre o auto-arranjo da molécula de colágeno influencia a ordenação e a organização padrão das fibras no processo estrutural supraorganizado. $O$ auto-arranjo e a supraorganização estrutural intrínsica contém as características fisico-químicas para transmitir sinais (piezoeletricidade, piroeletricidade, geometria molecular para reconhecimento e fenômeno de adesão) para as células.

\section{I.6 TENDÃO}

De acordo com a definição de HOLLENSEHEAD (1990) o tendão é um tecido que liga um músculo a outras estruturas; assim, uma das extremidades está sempre ligada a um músculo. Na outra extremidade, as fibras do tendão sempre se aderem com o tecido fibroso da estrutura a que se unem comumente ao osso, onde elas são contínuas ao mesmo tempo com uma cobertura fibrosa externa, o periósteo e com as fibras que formam a substância do osso. Sua função é transmitir a força criada no músculo para os ossos tornando possível o movimento articular.

Os tendões normais são brilhantes, brancos e possuem uma textura fibroelástica, o que demonstra uma grande resistência a cargas mecânicas (KHAN et al., 1999; JÓZSA \& KANNUS, 1997; MCNEILLY et al., 1996; STOLINSKI, 1995; BIRK \& TRELSTAD, 1986).

As fibras colágenas dos tendões são orientadas de modo a oferecer o máximo de resistência às forças que normalmente atuam sobre o tecido 
(JUNQUEIRA \& CARNEIRO, 1990). Por isso, essas fibras de colágeno são orientadas longitudinalmente, transversalmente e horizontalmente com fibrilas de colágeno longitudinais formando cordões espirais. Esta complexa estrutura promove ao tendão uma capacidade de equilibrar forças longitudinais, transversais, horizontais e rotacionais durante os movimentos e atividades (JÓZSA \& KANNUS, 1997).

Porém, segundo CULAW et al. (1999) grande parte das fibras são orientadas em paralelo ao eixo longitudinal do tendão, o que permite resistir e transmitir eficientemente às forças unidirecionais geradas dos músculos para os ossos.

No tendão há um tecido conjuntivo frouxo que o circunda denominado paratendão. $O$ paratendão tem a função de possibilitar o livre movimento do tendão contra os tecidos circunvizinhos. Logo abaixo do paratendão uma fina bainha de tecido conjuntivo chamada de epitendão circunda 0 tendão. $O$ endotendão circunda os feixes de colágeno mais internos do tendão (KHAN et al., 1999; JÓZSA \& KANNUS, 1997; REYNOLDS \& WORRELL, 1991).

Para verificação do nível de organização molecular das fibras colágenas no tendão há diversos métodos sendo empregados, tanto nas ocasiões onde a morfologia está preservada, como naquelas onde ocorre o processo de reparo desta estrutura corporal.

\section{I.6.1 ARQUITETURA INTERNA DOS TENDÕES}

O tendão é formado por fibroblastos e matriz extracelular, na qual estão imersos as proteínas fibrosas de colágeno e elastina, as proteoglicanas, as 
glicoproteínas e os mucopolissacarídeos. Sendo o colágeno o maior componente da matriz extracelular, abrangendo cerca de $86 \%$ a $95 \%$ do peso úmido do tendão. No tendão as fibras colágenas possuem uma disposição que é resultado do seu processo de maturação, sendo usualmente organizadas em fascículos de fibras que contém unidades menores denominadas fibrilas (ENWEMEKA \& SPIELHOLZ, 1992). As fibrilas de colágeno são longas e cristalinas, em tendões as fibrilas e fibras são altamente alinhadas. $O$ desenvolvimento sistemático desta hierarquia é requerido para a integridade estrutural e função normal dos tendões (BIRK et al., 1997; BIRK \& TRELSTAD, 1986).

Segundo BIRK et al., (1989) e BIRK \& TRELSTAD (1986), a organização do compartimento extracelular é determinado primariamente pelo fibroblasto onde há três níveis de organização da matriz: fibrilas de colágeno, feixes de fibras e macroagregados que irão depender do tecido biológico específico.

Dependendo das proporções de ácido hialurônico e sulfato de condroitin a hidratação da matriz extracelular pode variar. De acordo com JÓZSA \& KANNUS (1997), a capacidade das proteoglicanas e glicosaminoglicanas de se ligar às moléculas de água da matriz é importante para as propriedades biomecânicas do tendão de resistir às forças compressivas, além de promoverem estabilização do sistema colagenoso do tecido conjuntivo.

\section{I.7 TENDÃO DO CALCÂNEO}

Através da continuação do músculo gastrocnêmio e sóleo inicia-se o tendão do calcâneo. Na sua origem o tendão do calcâneo é largo, tornando-se 
mais estreito e irregular distalmente; onde insere-se na porção médio-posterior do calcâneo através de uma rígida expansão fibrocartilaginosa.

O tendão do calcâneo normal consiste de fibras colágenas orientadas no eixo longitudinal do tendão com poucos fibroblastos intercalados entre os feixes (ENWEMEKA, 1989a, b). Algumas fibras de elastina também podem ser vistas entre os feixes de fibras colágenas.

Segundo JÓZSA \& KANNUS (1997), criam-se estresses nas diferentes partes do tendão do calcâneo, visto que: o tendão do calcâneo absorve forças no plano sagital (flexão plantar e dorsal) e no plano frontal (inversão e eversão).

Quando cerca de $2 \%$ do comprimento do tendão é estirado perde-se a morfologia ondulada encontrada no estado de repouso das fibras de colágeno (PLAPLER et al., 2001; JÓZSA \& KANNUS, 1997; STOLINSKI, 1995; REYNOLDS \& WORRELL, 1991).

De acordo com ENWEMEKA et al. (1988), a resistência do tendão do calcâneo à estiramentos é definida pela densidade numérica, organização e arranjo das fibrilas dentro do tendão.

O tendão do calcâneo tem durante o suporte de peso e a locomoção uma alta capacidade de resistir a grandes forças requeridas.

\subsubsection{RUPTURA DO TENDÃO DO CALCÂNEO}

Segundo HIPÓCRATES citado por KURTZ (1996), se o tendão do calcâneo fosse lesado ou cortado, além de causar febre, induziria ao choque, desestruturaria a mente e em sua evolução acabaria trazendo a morte. 
De acordo com AMBROISE PARÉ em 1575 citado por CETTI (1993), a ruptura do tendão do calcâneo tem recebido bastante atenção por vários pesquisadores. Esta atenção é baseada no fato de que a ruptura do tendão do calcâneo além de ser uma lesão grave é uma das mais comuns dentre as lesões tendíneas (STHENO-BITTEL et al., 1998).

Em alguns casos de ruptura do tendão do calcâneo há sintomas prévios à lesão como dor e rigidez. No entanto, também há os casos que não apresentam nenhum sintoma que antecede à ruptura (PUDDU, 1976).

REYNOLDS \& WORRELL (1991), refere que as lesões do tendão do calcâneo ocorrem com grande incidência em esportes de alto impacto como a corrida e o salto. Estes tipos de atividades esportivas permitem que o tendão seja bastante estressado durante a contração muscular excêntrica do gastrocnêmio e do sóleo.

Segundo SALOMÃO et al. (1993), a maior frequência de ruptura do tendão do calcâneo ocorre nos futebolistas e com menor incidência nos tenistas e bailarinas.

Segundo SOMA \& MANDELBAUM (1995), 75\% de todas as rupturas do tendão do calcâneo ocorrem em atletas com idades entre 30 e 40 anos.

A degeneração colagenosa, que ocorre com o avanço da idade, provoca mudanças biomecânicas importantes no tendão. O conteúdo de colágeno aumenta enquanto que a elastina e as proteoglicanas da matriz extracelular diminuem, terminando com perda da elasticidade do tecido, o conteúdo de água também declina agravando o quadro. A renovação do colágeno é reduzida com o avanço da idade retardando o processo de reparo (KANNUS \& JÓZSA, 1991). 
Segundo ALMEKINDERS \& DEOL (1999); STHENO-BITTEL et al. (1998) e SOMA \& MANDELBAUM (1995) uma sobrecarga de trabalho sobre o tecido tendíneo leva-o à fadiga, com conseqüência há uma reação inflamatória com rupturas parciais ou totais do tendão. Microtraumas repetitivos no tendão induzem a ruptura tendínea.

A ruptura do tendão do calcâneo normalmente é precedida por alterações degenerativas onde há redução do fluxo sanguineo para o tendão com resultante hipóxia local. A alteração da nutrição e da atividade metabólica também predispõem a essas alterações (ALMEKINDERS \& DEOL, 1999; SALOMÃO et al., 1993).

\section{I.8 PROCESSO DE REPARO TECIDUAL}

O processo de reparo tecidual é uma perpetuação de acontecimentos que envolvem diversas reações de um complexo processo biológico, cujo objetivo principal é o fechamento da lesão ou o reparo dos tecidos envolvidos (PARIZOTTO, 1998; JÓZSA \& KANNUS, 1997).

O processo de reparo de tendões é similar a outros processos de reparação que ocorrem com outros tecidos biológicos (CHAN et al., 1997).

O processo de reparo tendíneo segue uma sucessão de eventos: a) proliferação e migração por vários tipos de células; b) síntese de colágeno; c) angiogênese para a formação do tecido de granulação; d) e por fim, orientação das células do tendão e fibras de colágeno de maneira altamente organizada na tentativa de restaurar a estrutura e função do tendão lesado. 
Devido a sua baixa vascularidade, oxigenação e nutrição, o tecido tendíneo possui baixa capacidade de reparação. No entanto, diversos estudos demonstraram que quando o tendão lesado é estimulado por meios biofísicos apropriados este cicatriza adequadamente (ENWEMEKA \& REDDY, 2000; PARIZOTTO, 1998; REDDY et al., 1998a, b; GUM et al., 1997; ENWEMEKA, 1991a, b; ENWEMEKA et al., 1990; ENWEMEKA, 1989b).

Baseado nos estudos de JÓZSA \& KANNUS, (1997), ENWEMEKA \& SPIELHOLZ, (1992), KUSCHNER et al. (1991), ENWEMEKA (1989a), o processo de reparação se dá, com intuito didático, em 3 fases distintas, porém sobrepostas:

1) Fase inflamatória;

2) Fase Neoangiogênica e Proliferativa;

3) Fase de Remodelamento.

Para o tendão as duas últimas fases são essenciais para um adequado reparo tecidual onde haverá uma intensa proliferação celular (fibroblastos); síntese de fibrilas de colágeno e alinhamento das fibras no eixo longitudinal do tendão (ENWEMEKA, 1989a).

\section{l.8.1 FASE INFLAMATÓRIA (1 a 7dias pós lesão)}

A inflamação é um pré-requisito para que o processo de reparo aconteça. Por isso, a inflamação inicia-se imediatamente após a lesão, sendo uma resposta natural do organismo ao trauma lesivo. 
O trauma lesivo provoca ruptura dos vasos sanguíneos. Ocorrendo extravasamento de sangue, plasma e fluidos teciduais para a área lesada (JÓZSA \& KANNUS, 1997; GIGANTE, 1996).

De acordo com GOGIA (1995), dentro de 24 a 48 horas ocorre a fase inflamatória aguda.

Após a lesão há hemostasia e as células e elementos dissolvidos no sangue formam o hematoma, do qual células migram e aderem na ferida.

O estágio inicial da inflamação é caracterizado por alterações vasoativas que promovem a exsudação de fagócitos do sangue para as margens da lesão. A infiltração celular ocorre nas primeiras 24 horas e continua por poucos dias (JÓZSA \& KANNUS, 1997; PEREIRA, 1994; REED \& ZARRO, 1990).

Segundo GOGIA (1995), fatores quimiotáticos e vasoativos como a norepinefrina e serotonina são secretados imediatamente após a lesão, promovendo a vasoconstrição dentro dos primeiros 5 a 10 minutos.

Simultâneamente, as plaquetas reúnem-se ao redor do epitélio dos vasos lesados e ao colágeno exposto, liberando fosfolipídeos que estimulam o mecanismo de coagulação. Fibrinas e fibronectinas formam ligações transversas com o colágeno, o que resulta em uma tênue estrutura que estanca a hemorragia local e funciona como resistência a forças de tensão durante a fase inicial de reparo (JÓZSA \& KANNUS, 1997).

Independente de sua origem, os tenócitos migram para o sítio de reparo durante as duas semanas iniciais e produzem colágeno e glicosaminoglicanas (JÓZSA \& KANNUS, 1997). Por volta do $3^{\circ}$ dia pós-lesão os fibroblastos iniciam a produção de fibrilas que se agregam ao acaso no espaço extracelular, 
isso de certa forma colabora para proteger o tecido tendíneo contra as forças aplicadas no início da cicatrização (ENWEMEKA et al., 1988).

A vasodilatação seguida da vasoconstrição transiente provoca um aumento na pressão hidrostática e no fluxo sanguíneo. Com isso, permeabilidade vascular aumenta em resposta as reações químicas promovidas pela histamina que é liberada pelas plaquetas, mastócitos e leucócitos granular; e pela bradicinina que, além disso, estimula a liberação de prostaglandinas nas fases mais tardias da inflamação. As prostaglandinas PGE-1 aumentam a permeabilidade vascular, já a PGE-2 atraem leucócitos (JÓZSA \& KANNUS, 1997; REED \& ZARRO, 1990).

Como conseqüência desse estágio inicial, o plasma é extravasado entrando em contato com o tecido lesado. Clinicamente observa-se ao redor da região lesada calor, rubor, dor e edema (REED \& ZARRO, 1990).

As primeiras células que migram para o sítio lesado são os leucócitos polimorfonucleares (neutrófilos), essas células se originam dos capilares ainda escoantes e iniciam a ingestão de contaminantes e fragmentos produzidos pelo ferimento. Esse processo de migração e ingestão permanece por 24 horas após a lesão (ENWEMEKA \& SPIELHOLZ, 1992; ENWEMEKA, 1989a).

Quando os leucócitos mononucleares (monócitos) penetram no sítio lesado, cerca de 1 a 2 dias após a lesão, se transformam em macrófagos teciduais e juntos com os linfócitos dão continuidade a fagocitose (GOGIA, 1995; ENWEMEKA, 1989a).

Durante 1 a 2 semanas após à lesão, há uma extensa infiltração por leucócitos polimorfonucleares, macrófagos e fibroblastos que permanecem no tecido de granulação (HIRANUMA, 1996). 
Na maior parte da fase de reparo os macrófagos estão presentes. Além de fagocitarem o sangue extravasado e os produtos da destruição tecidual que não fram solubilizados pelos neutrófilos, eles fagocitam os neutrófilos mortos restantes na área lesada. Além da fagocitose eles secretam fatores de crescimento e fibronectina, os quais promovem a quimiotaxia dos fibroblastos, fixação e migração destas células no local da lesão estimulando a sua proliferação. Os macrófagos e fibroblastos interagem um com o outro regulando a fase inflamatória e o processo de remodelamento da matriz extracelular (KAKAR et al., 1998). Alguns monócitos, que são células imaturas, intensificam sua capacidade de defesa no momento que penetram nos tecidos e convertem-se em macrófagos (ENWEMEKA \& SPIELHOLZ, 1992; REED \& ZARRO,1990).

As células inflamatórias atuam principalmente na remoção de tecido necrótico e microorganismos localizados na área lesada. Quando o objetivo é alcançado por volta do 5 ao 7 dia pós lesão, inicia-se então a fase proliferativa (JÓZSA \& KANNUS, 1997).

A resposta imune à lesão é outro aspecto da fase inflamatória, a qual é formada por linfócitos $\mathrm{T}$ e B, produzidos por tecidos linfóides, que irão destruir microorganismos e toxinas específicas. Os linfócitos B produzem as imunoglobulinas específicas (anticorpos), as quais agem através do sistema complemento, neutralizando ou destruindo os antígenos. Os linfócitos $\mathrm{T}$, liberam linfocinas que atuam na rejeição dos órgãos transplantados e secretam a interleucina-2 que potencializa a ação dos linfócitos B (PARIZOTTO, 1998).

Por meio de toxinas ou complexos imunes é ativado as proteínas enzimáticas do sistema complemento, os quais estão envolvidos nas etapas do 
processo inflamatório, incluindo a fagocitose, aumento da permeabilidade vascular e a quimiotaxia de neutrófilos. O complemento possui um efeito intensificador da inflamação, promovendo a liberação da histamina pela ativação dos mastócitos e basófilos (REED \& ZARRO,1990).

\subsubsection{FASE NEOANGIOGÊNICA E PROLIFERATIVA (5 a 21 dias pós lesão)}

Segundo ENWEMEKA (1989a), a neoangiogênese inicia-se por anastomoses de capilares sanguineos próximos à área lesada, esses por sua vez se projetam para o interior da lesão formando inúmeras ramificações e desenvolvendo uma rica rede vascular. A neovascularização é essencial para que o processo de reparção ocorra, pois ela garante um abundante suporte de $\mathrm{O}_{2}$ e nutrientes para a área lesada, removendo o $\mathrm{CO}_{2}$ e outros metabólicos.

GELBERMAN (1985), observou o aparecimento de novos vasos sanguíneos em tendões lesados por volta do $7^{0}$ dia após a lesão.

São os vários componentes dos fluidos da lesão que promovem a angiogênese. Dentre os componentes inclui-se prostaglandinas, fatores de crescimento macrofágico, leucócitos polimorfonucleares, linfócitos $T$ e fator de crescimento epidermal (EGF) (ENWEMEKA \& SPIELHOLZ, 1992).

É uma citocina o fator de crescimento básico dos fibroblastos (FGFß). Esta citocina tem importante função na angiogênese, ele é secretato pelos fibroblastos e células inflamatórias do tendão (CHANG et al., 1998).

Segundo CHAN et al. (1997), o fator de crescimento fibroblástico (FGF $\beta$ e FGF2) é envolvido na cicatrização por regular a proliferação de fibroblastos e 
a síntese de colágeno, induzir ativadores plasminogênicos e colagenases no remodelamento do tendão e facilitar a migração e proliferação de células endoteliais na angiogênese.

Neutrófilos, plaquetas, monócitos, macrófagos e linfócitos mantém-se durante toda a fase inflamatória, juntamente com o sistema imune. Previamente a síntese de colágeno, novos vasos sanguineos são formados; esta neovascularização fornece um adequado suporte de $\mathrm{O}_{2}$, assim como assegura a remoção de $\mathrm{CO}_{2}$ e outros metabólicos.

Segundo JÓZSA \& KANNUS (1997) e PEREIRA (1994) a fase proliferativa inicia-se com a chegada de fibroblastos, miofibroblastos e células endoteliais na área lesada. A migração e a proliferação dessas células é estimulada por fatores de crescimento liberados pelas plaquetas e macrófagos teciduais. Segundo MAXWELL (1992), a estimulação dos fibroblastos por substâncias liberadas através das plaquetas e dos macrófagos, que promovem seu crescimento, acompanham a retração vascular no processo de reparo tecidual e são responsáveis pela síntese de colágeno e sua deposição na matriz extracelular. Os níveis de lactato aumentados estimulam a atividade da prolihidroxilase, uma enzima essencial na síntese de colágeno, e sob a condição de hipóxia os fibroblastos produzem um precursor polipeptídico do colágeno. Contudo a presença de oxigênio é fundamental para a hidroxilação dos aminoácidos lisina e prolina e para a liberação do colágeno Além disso, para que se estabeleça a maturação e as ligações cruzadas do colágeno há necessidade de oxigênio.

De acordo com PARIZOTTO (1998), há diversos fatores de crescimento liberados pelas plaquetas que possuem uma função essencial na proliferação 
de céluas e matriz extracelular. Alguns já são conhecidos como fator de crescimento derivado das plaquetas (PDGF), fator de crescimento transformador $(T G F-\propto)$, fator de crescimento do fibroblasto (FGF), fator de crescimento epidermal (EGF) e o fator de crescimento neural (NGF).

A fibroplasia e fibrilogênese tem início poucos dias após a lesão, essas etapas da cicatrização impõem uma tensão mecânica ao tecido tendíneo apressando a polimerização das fibrilas dentro dos feixes de colágeno (ENWEMEKA et al., 1988).

Durante a fase de proliferação alguns fibroblastos adquirem características ultraestruturais, funcionais, imunológicas e químicas que os distinguem dos fibroblastos teciduais ativos esses fibroblastos diferenciados chamam-se miofibroblastos. Embora os miofibroblastos possuem a morfologia do fibroblasto, eles contêm grande quantidade de microfilamentos de actina e miosina em seu interior (JUNQUEIRA \& CARNEIRO, 1990).

Os miofibroblastos são capazes de se contrairem e moverem, contribuindo para a contração da região cicatricial, além de secretarem grande variedade de moléculas como colágeno, fibronectina, elastina, ácido hialurônico, glicosaminoglicanas e mucopolissacarídeos (PARIZOTTO, 1998).

Durante esta fase os fibroblastos e miofibroblastos mostram uma extensa proliferação, síntese de matriz extracelular e abundância de vesículas citoplasmáticas no interior dos fibroblastos (sugerindo secreção de fibras de colágeno).

A combinação de novos capilares, fibroblastos, miofibroblastos e matriz extracelular formada por colágeno e outros componentes não colagenosos, dão 
origem a um tecido conjuntivo ricamente vascularizado que preenche a área lesada (JÓZSA \& KANNUS, 1997; ENWEMEKA \& SPIELHOLZ, 1992).

Esse tecido conjuntivo frouxo, rico em capilares sanguineos e contendo leucócitos e matriz extracelular formada por fibras colágenas finas (predominantemente colágeno tipo III), ácido hialurônico e moderada quantidade de proteoglicanas recebe o nome de tecido de granulação (PEREIRA, 1994).

O depósito de colágeno aumenta progressivamente com o tempo atingindo seu pico por volta do $14^{\circ}$ dia após a lesão. Paralelamente começa a ocorrer redução da síntese de glicosaminoglicanas, especialmente de ácido hialurônico, neste período o colágeno tipo I começa a predominar sobre o tipo III. Há simultâneas degradações de colágeno, resultando em uma grande quantidade de remodelamento, com lise de algumas fibras, agregação e aumento de novas fibras (ENWEMEKA \& SPIELHOLZ, 1992).

Com o processo de fibrilogênese, as fibras de colágeno se tornam progressivamente mais espessas e numerosas, as células fagocitárias vão desaparecendo e o tecido de granulação passa a ser constituído por um tecido conjuntivo progressivamente mais denso e menos vascularizado (ENWEMEKA, 1989a).

O tecido cicatricial ainda é dinâmico; a contração da cicatriz é contínua aproximando ainda mais as bordas da área lesada. Segundo GOGIA (1995), a contração segue uma taxa uniforme aproximada de $0,6 \mathrm{~nm}$ a $0,75 \mathrm{~mm}$ ao dia e independe do tipo de ferida, mas depende da nutrição tecidual. 
O colágeno existente vai sendo remodelado progressivamente, há um aumento das ligações cruzadas intermoleculares, tornando o tecido mais resistente e organizado (ENWEMEKA \& SPIELHOLZ, 1992).

De acordo com GIGANTE (1996), ENWEMEKA \& SPIELHOLZ (1992), ENWEMEKA (1989a), há um maior alinhamento das fibras de colágeno no eixo longitudinal do tendão após um período de 21 dias de reparo tecidual.

A carga mecânica imposta precocemente ao tecido acelera 0 alinhamento paralelo e a polimerização das fibrilas dentro das fibras de colágeno. Com isso, o processo de alinhamento fibrilar pode-se iniciar no 4 a 5 dias após ruptura ou incisão tendínea (ENWEMEKA et al., 1988).

Segundo estudos de ENWEMEKA (1989a) e ENWEMEKA \& SPIELHOLZ, (1992), através de análises por microscopia eletrônica, pode ser visualizado uma elevação do alinhamento das fibras de colágeno no eixo longitudinal do tendão após um período de 21 dias de reparo tecidual.

\subsubsection{FASE DE REMODELAMENTO (14 a 360 dias pós lesão)}

Recentes estudos relatam que o processo de remodelamento se inicia por volta da $2^{\mathrm{a}}$ semana de cicatrização e se estende por um período de 1 ano ou mais (JÓZSA \& KANNUS, 1997; TILLMAN \& CUMMINGS, 1992b), sendo este cerca de 30 semanas para uma tenotomia parcial (POSTACCHINI \& DE MARTINO, 1980).

JÓZSA \& KANNUS, (1997), acreditam que o tendão lesado leva cerca de 4 a 12 meses para alcançar uma boa força tensiva, porém os mesmos 
autores relatam que o tecido tendíneo lesado nunca conseguirá atingir a morfologia e função biomecânica de tendões normais.

Nesta fase a cicatriz contém fibras colágenas bem organizadas. O tecido gradualmente muda de predominantemente celular para fibroso, com grande quantidade de fibras colágenas. Há um aumento gradual de força própria da cicatriz e um aumento da estabilidade das ligações moleculares. Durante este período haverá um contínuo decréscimo da capacidade da cicatriz responder a tratamentos (ENWEMEKA \& SPIELHOLZ, 1992).

Os fibroblastos possuem formas alongadas com algumas reentrâncias citoplasmáticas correndo entre os feixes de colágeno que agora se encontram organizados no eixo longitudinal do tendão (ENWEMEKA, 1989a).

O aumento da resistência do tecido lesado decorre do remodelamento do colágeno, principalmente pelo aumento do colágeno tipo I e do aumento das ligações cruzadas entre as moléculas (JÓZSA \& KANNUS, 1997; PEREIRA, 1994). A maturação do colágeno e o realinhamento linear são normalmente vistos por volta do 5ำ ao 6 mês após a lesão (JÓZSA \& KANNUS, 1997).

Por volta de 60 dias, as fibras de colágeno tipo I são compactas e espessas. Quando a cicatriz encontra-se œmpletamente matura cerca de 3\% de seus elementos são celulares (fibroblastos, miofibroblastos, macrófagos) e o restante é colágeno (JÓZSA \& KANNUS, 1997; ENWEMEKA \& SPIELHOLZ, 1992).

Em um estudo feito por ENWEMEKA (1992), tendões tenotomizados que foram submetidos à carga funcional no $5^{0}$ dia pós lesão, tiveram uma maior área de secção transversa em relação aos tendões controles que não foram 
submetidos à carga, isso ocorreu devido a maior quantidade de fibras colágenas organizadas no eixo longitudinal do tendão.

Portanto, é plausível afirmar que a carga funcional acelera a proliferação fibroblástica, a fibrilogênese e o remodelamento da matriz extracelular, já que existe uma forte correlação entre a força dos tendões e o número, tamanho e arranjo das fibras de colágeno (POSTACCHINI \& DE MARTINO, 1980).

Segundo PARIZOTTO (1998), o processo de reparo tecidual ocorre como consequência da destruição produzida pela inflamação. O organismo tenta realizar ações concatenadas no sentido de reconstituir a morfologia dos tecidos envolvidos e dar maior funcionalidade para estes tecidos. Normalmente há um equilíbrio entre a formação de colágeno e a sua degradação. Uma das formas de fornecer maior funcionalidade aos tecidos lesados é a recuperação ou a substituição por células do mesmo tipo que havia antes da lesão.

\section{I.8.4 CICATRIZACÃO INTRÍNSICA E EXTRÍNSICA DO TECIDO} TENDÍNEO

Segundo JÓZSA \& KANNUS (1997), GELBERMAN et al. (1985), LUNDBORG (1985), MANSKLE et al. (1984) e MANSKLE \& LESKER (1984) o tecido tendíneo cicatriza por regeneração celular promovida por células dos próprios cotos tendíneos (cicatrização intrínsica).

Já segundo KAKAR et al. (1998), TAKASUGI et al. citado por JÓZSA \& KANNUS (1997), POTENZA, citado por JÓZSA \& KANNUS (1997) afirmam que o tendão cicatriza pela atividade celular do tecido peritendinoso (cicatrização extrínsica). 
Um terceiro grupo de estudiosos sustenta a idéia de que o tendão cicatriza através de ambos os processos de reparo (cicatrização intrínsica e extrínsica) (RUSSELL \& MANSKLE 1990; LUNDBORG et al., 1985; MANSKLE \& LESKER, 1984).

\section{I.8.5 CICATRIZACÃO INTRÍNSICA}

Tem sido demonstrado em modelos in vitro e in vivo a capacidade de cicatrização intrínseca de tendões em processo de reparo, onde a fonte celular extrínsica, suprimento sanguineo e fluido sinovial foram completamente excluídos (MANSKLE \& LESKER, 1984).

De acordo com GELBERMAN et al. (1985), a transformação dos fibroblastos do epitendão provoca a fagocitose, enquanto que a síntese de colágeno é feita pelas células do epitendão e endotendão. Essas células migram em direção a região lesada para fazer a reparação.

GELBERMAN et al. (1985), menciona a importância da vascularidade intratendínea no processo de reparo intrínsico.

Segundo LUNDBORG et al. (1985), o reparo intrínsico de tendões ocorre através da proliferação e síntese de colágeno tanto das camadas superficiais e profundas do tendão.

No estudo de MANSKLE et al. (1984), feito com tendões flexores dilacerados transversalmente demonstrou a capacidade de cicatrização intrínsica desses tendões, onde houve ausência de fontes celulares extrínsicas e ausência de nutrição pela circulação sanguinea ou fluido sinovial. A cicatrização ocorreu pela diferenciação dos fibroblastos do epitendão, onde 
estes migraram para o local da lesão e removeram as células debridadas e fragmentos de colágeno, ao mesmo tempo que sintetizaram novos colágenos.

\section{I.8.6 CICATRIZACÃO EXTRÍNSICA}

O processo de cicatrização extrínsica consiste no espessamento e diferenciação das células do epitendão, migração celular e fagocitose pelos macrófagos com importante participação dos fibroblastos.

Segundo POTENZA, citado por JÓZSA \& KANNUS, (1997), houve reparo do tendão suturado e imobilizado, devido o crescimento do tecido de granulação, derivado de estruturas vizinhas ao tendão.

TAKASUGl et al. citado por JÓZSA \& KANNUS, (1997), refere que o reparo do tendão ocorre pelo tecido tenosinovial onde células fibroblásticas cobrem e cicatrizam a área lesada.

É na bainha sinovial ou no epitendão externo ao tecido tendíneo que a ativação celular no processo de reparo tem se monstrado maior, quando comparados com o endotendão. A produção de fatores de crescimento no tecido sinovial como o fator de crescimento beta transformador I (TGF $\beta-$ I), sugere que a sinóvia possui um papel dominante na iniciação e perpetuação da formação cicatricial do tendão no inicío do reparo (KAKAR et al., 1998). 


\subsubsection{CICATRIZACÃO INTRÍNSICA E EXTRÍNSICA}

Para RUSSELL \& MANSKLE (1990), o processo de reparação do tendão lesado ocorre pela proliferação e migração das células do epitendão (externas), assim como a proliferação das células do endotendão (internas).

De acordo com LUNDBORG \& RANK e MANSKLE \& LESKER, citado por JÓZSA \& KANNUS, (1997), quando a microcirculação intratendínea e o fluido sinovial são preservados pela combinação de técnicas de suturas adequadas e reconstrução da bainha sinovial os próprios tenócitos através de expressões gênicas promovem a cicatrização intrínsica. Porém, quando a nutrição tendínea é prejudicada por técnicas de suturas inadequadas ou ressecção da bainha sinovial mecanismos extrínsicos promovem a cicatrização do tecido tendíneo.

\section{I.9 EFEITOS DO UST SOBRE O REPARO TECIDUAL}

Há evidências consideráveis que a terapia por UST pode agir como um estímulo para as células envolvidas no processo de reparo tecidual, particularmente na fase inflamatória e proliferativa deste. A terapia por UST pode afetar cada fase deste processo, resultando na aceleração da cicatrização (DYSON, 1995). Porém, revisões sistemáticas e meta-análises têm repetidamente concluído que não há evidências suficientes para suportar os benefícios os efeitos do ultra-som nas doses freqüentemente utilizadas nas clínicas (WARDEN, 2003). 
CHRISTINE et al. (2003), a proposta deste estudo foi avaliar os efeitos do UST sobre as propriedades estrutural e atuação funcional do tendão de Aquiles em processo de reparo. Os tendões foram hemi-secionados cirurgicamente e tratados com um UST de $1 \mathrm{MHz}$ contínuo. Neste experimento houve dois grupos tratados, onde um deles recebeu $1 \mathrm{~W} / \mathrm{cm}^{2}$ por 4 minutos de irradiação ultra-sônica e o outro $2 \mathrm{~W} / \mathrm{cm}^{2}$ por 4 minutos. Os resultados foram coletados após teste biomecânico. A resistência tênsil máxima dos tendões foi de $61.7 \mathrm{~N} / \mathrm{mm}$ (grupo controle), $72.3 \mathrm{~N} / \mathrm{mm}$ (grupo $1 \mathrm{~W} / \mathrm{cm}^{2}$ ) e $85.1 \mathrm{~N} / \mathrm{mm}$ (grupo $2 \mathrm{~W} / \mathrm{cm}^{2}$ ). A dureza dos tendões foi de $71.5 \mathrm{~N} / \mathrm{mm}$ (grupo controle), 75.0 $\mathrm{N} / \mathrm{mm}$ (grupo $1 \mathrm{~W} / \mathrm{cm}^{2}$ ) e $74.2 \mathrm{~N} / \mathrm{mm}$ (grupo $2 \mathrm{~W} / \mathrm{cm}^{2}$ ). A carga-relaxamento foi de $38.4 \mathrm{~N} / \mathrm{mm}$ (grupo controle), $32.6 \mathrm{~N} / \mathrm{mm}$ (grupo $1 \mathrm{~W} / \mathrm{cm}^{2}$ ) e 36.4 (grupo 2 $\mathrm{W} / \mathrm{cm}^{2}$ ). Portanto, o estudo demonstrou que $1 \mathrm{~W} / \mathrm{cm}^{2}$ e $2 \mathrm{~W} / \mathrm{cm}^{2}$ em um ultrasom contínuo estimula o processo de reparo de tendão. Porém, não houve diferença estatística quando comparado os dois tipos de tratamento, apesar da dose mais alta aparentar ser mais eficiente. Porém, BARNETT et al. (1994) alerta, quanto mais alta é a intensidade de irradiação ultra-sônica mais provável a ocorrência de danos biológicos.

SWIST-CHMIELEWSKA et al. (2002), estudaram os efeitos do UST na cicatrização de úlceras venosas, em duas doses usualmente utilizadas em fisioterapia, $0,5 \mathrm{~W} / \mathrm{cm}^{2}$ e $1 \mathrm{~W} / \mathrm{cm}^{2}$. Foi avaliado as mudanças de área e volume da úlcera. Os resultados demonstraram que o grupo tratado com $0,5 \mathrm{~W} / \mathrm{cm}^{2}$ obteve o melhor resultado.

SAINI et al. (2002), verificaram os efeitos do UST no tendão de cachorros em processo de reparo, utilizando uma intensidade de $0,5 \mathrm{~W} / \mathrm{cm}^{2}$ durante 10 dias. Os resultados desta pesquisa experimental foram obtidos 
através de observações clínicas, ultra-sonografia, observações macroscópicas e histomorfologia. Clinicamente, os cachorros deixaram de manquitolar antes do grupo controle. Na ultra-sonografia, a eco-textura mais próxima de um tendão normal iniciou-se nos tendões tratados com UST. As observações macroscópicas sugerem que os tendões tratados com UST possuem uma menor adesão. Histologicamente, os tendões de Aquiles tratados com UST apresentaram uma formação de fibras mais avançada do que o grupo controle. Como resultado dessas avaliações, concluiu-se que o UST em $0,5 \mathrm{~W} / \mathrm{cm}^{2}$ estimula o processo de reparo dos tendões de Aquiles de cachorros.

DYSON \& LUKE, apud KITCHEN \& PARTRIDGE (1990), consideraram algumas variáveis para determinar os efeitos do UST na degranulação de mastócitos e sugerem com os resultados que o UST de baixa intensidade pode atuar sobre tais células no processo de lesão ecidual e que a liberação dos grânulos mastocitários pode ser um caminho para explicar a aceleração do reparo tecidual.

O que se pode observar na fase inflamatória inicial do reparo é uma aceleração do processo pelo UST, aumentando a liberação de fatores de crescimento pela desgranulação dos mastócitos (FYFE \& CHAHL, 1982), plaquetas e macrófagos (YOUNG \& DYSON, 1990a).

YOUNG \& DYSON (1990b), estudaram o efeito do UST na angiogênese, em lesões de $1 \mathrm{~cm}^{2}$ na pele de 36 ratas Wistar. Os animais foram divididos em 2 grupos. O grupo 1 recebeu tratamento com UST durante os cinco primeiros dias pós lesão e foram subdivididos em 3 subgrupos: (A) Controle placebo, (B) Tratado com UST na freqüência de $0,75 \mathrm{MHz}$, intensidade de $0,1 \mathrm{~W} / \mathrm{cm}^{2}$ (SATA), pulsado 1:4, tempo de 5 minutos/dia e o (C) Com diferença na 
freqüência $(3,0 \mathrm{MHz})$. O grupo 2 recebeu tratamento com UST durante os 7 dias pós lesão e foram subdivididos da mesma forma que o grupo 1.

A análise para quantificar a angiogênese foi a de microdensitometria e análise de imagem.

Como resultados houve um aumento significativo do número de vasos quando as lesões foram tratadas com UST no grupo (a) na freqüência de 0,75 $\mathrm{MHz}$, quando comparada com o grupo controle. Não houve diferença estatística entre as freqüências dentro do grupo $(A)$. Houve um aumento na vascularização nos subgrupos tratados com UST do grupo (B) em relação ao controle, porém não foi estatisticamente significante.

Os dados deste trabalho sugerem que o UST pode infuenciar positivamente a fase inicial do processo de reparo tecidual, isto é na fase inflamatória, em relação a angiogênese.

A fase proliferativa inicia-se precocemente, se aplicado UST na fase anterior (inflamatória). Há evidências de que a exposição ao UST nesta etapa do processo provoca a redução da sua duração, atuando no sentido do início precoce da fase de remodelamento. Para isso, a contração da cicatriz é um importante passo que parece ser acelerada pela liberação de fatores de crescimento estimulada pelo UST. As doses utilizadas nestas etapas estão na faixa de $0,1 \mathrm{~W} / \mathrm{cm}^{2}$ a $0,2 \mathrm{~W} / \mathrm{cm}^{2}$ de intensidade espacial e temporal médias, usando modo contínuo, ou doses maiores $\left(0,6 \mathrm{~W} / \mathrm{cm}^{2}\right.$ a $\left.0,8 \mathrm{~W} / \mathrm{cm}^{2}\right)$ se utilizado na forma pulsada com ciclo de trabalho de 20\% (DYSON \& SMALEY, 1983).

ENWEMEKA (1989b), com objetivo de determinar os efeitos biomecânicos (força de tensão e capacidade de absorção de energia) da terapia por UST em cicatrização de tendão de Aquiles de coelhos, aplicou UST 
contínuo, freqüência de $1 \mathrm{MHz}$, intensidade $1 \mathrm{~W} / \mathrm{cm}^{2}$ por cinco minutos, método subaquático, diariamente durante os nove primeiros dias de pós operatório (PO). Ele encontrou um aumento na tensão de estiramento e aumento na capacidade de absorção energética no tecido dos tendões tratados em relação ao grupo placebo.

BYL et al. (1992), œm o intuito de estudar os efeitos do UST em baixas doses na cicatrização de feridas provocou 88 ferimentos em 18 porcos da raça Yucatan adultos, sendo 28 feridas completas de $1 \mathrm{~cm}^{2}$ de pele e epiderme, 28 feridas incompletas e 32 lesões por incisão de $6 \mathrm{~cm}$ de pele. $O$ tratamento com UST foi realizado por 5 dias consecutivos desde o $1^{\circ} \mathrm{PO}$, com os seguintes parâmetros: freqüência de $1 \mathrm{MHz}$, intensidade de $0,5 \mathrm{~W} / \mathrm{cm}^{2}$ por 3 dias e 1,5 W/cm ${ }^{2}$ nos 2 últimos dias, pulsado a 25\%, ERA de $5,0 \mathrm{~cm}^{2}$, por 5 minutos nas lesões parciais e 10 minutos nas totais, com gel estéril. Como resultados, houve um aumento significante na força de contração da ferida e na taxa de cicatrização, principalmente nas lesões completas. Houve significante desgranulação de mastócitos em todos os três tipos de lesão.

Os estudos dos efeitos benéficos do UST em relação aos tendões não se limitam em experimentos in vivo. No trabalho de (HARVEY et al., apud. MAXWELL 1992) culturas de fibroblastos humanos, quando expostas a UST contínuo, freqüência de $3 \mathrm{MHz}$, intensidade de $0,5 \quad \mathrm{~W} / \mathrm{cm}^{2}$ a 2,0 $\mathrm{W} / \mathrm{cm}^{2}$, sintetizaram um número maior de proteínas determinado pela incorporação de Hprolina, que a cultura que recebeu UST placebo. Portanto, parece haver um potencial terapêutico do UST para estimular o reparo tecidual que também poderia agir na deposição de colágeno e formação de cicatriz. 
RAMIREZ et al. (1996), observaram o efeito do UST na síntese de colágeno e proliferação de fibroblastos in vitro. Um total de 8 filhotes de ratos, com 3 a 5 dias foram sacrificados e seus tendões de Aquiles de ambas as patas foram removidos e cortados na espessura de $2 \mathrm{~nm}-3 \mathrm{~nm}$, afim de iniciar-se culturas de células primárias e neonatais. O UST foi aplicado em diferentes culturas, com os seguintes parâmetros: freqüência de $1 \mathrm{MHz}$, intensidade de $0,4 \mathrm{~W} / \mathrm{cm}^{2}$ por 3 minutos em dias intercalados (1, 3, 5, 7 e 9), ERA de 5,0 cm², com técnica estacionária e modo contínuo.

Como resultados, obtiveram um efeito satisfatório com o tratamento na síntese de colágeno quando a matriz está rompida, o que sugere efeitos benéficos em estágios iniciais do processo de reparo tecidual. Outro aspecto importante foi que o UST estimulou as células proliferativas, podendo ter uma importante influência durante a fase proliferativa do processo de reparo. Este estudo sugere o uso clínico do UST para estimular o crescimento de tecido conjuntivo quando este estiver em processo de reparo por lesão tecidual.

DYSON et al. (1968), relataram que o UST facilita o aumento do tecido em cicatrização da orelha de coelhos, comparado com os animais não tratados. O tratamento com UST foi iniciado 2 semanas após a lesão e continuado em 3 vezes por semana. As dosagens encontradas como mais efetivas foram 0.25 $\mathrm{W} / \mathrm{cm}^{2}$ e $0.5 \mathrm{~W} / \mathrm{cm}^{2}$ em pulsação a $20 \%$ e $0.1 \mathrm{~W} / \mathrm{cm}^{2}$, no modo contínuo, todos a 3,5 $\mathrm{MHz}$ e tempo de 5 minutos. Observaram, regeneração acima de $32 \%$ após 21 dias de tratamento com UST à $0,5 \mathrm{~W} / \mathrm{cm}^{2}$, pulsado a $20 \%$ verificaram ainda que o UST provoca um incremento metabólico pelo aumento da atividade enzimática. Sugeriram que o tratamento com UST tem o poder de interferir na formação química da cicatriz, pela polimerização do colágeno. O presente 
estudo levantou a hipótese que o UST pode controlar aderências nos tendões reparados cirurgicamente.

ENWEMEKA et al. (1990), relatam estudos que sugerem que os efeitos benéficos do UST, podem ser obtidos com baixas intensidades mais facilmente do que quando utiliza-se altas intensidades. Por exemplo, a exposição de cultura de fibroblastos a intensidades de $0,5 \mathrm{~W} / \mathrm{cm}^{2}$ a $1,0 \mathrm{~W} / \mathrm{cm}^{2}$ por 5 minutos, provoca aumento de cálcio intracelular, mediador de numerosos processos celulares, incluindo a síntese protéica. O mesmo não ocorre com dosagens de $1,5 \mathrm{~W} / \mathrm{cm}^{2}$, por 15 minutos, que produz danos vasculares.

O objetivo do estudo foi verificar os efeitos do UST de baixa intensidade na força de tensão e capacidade de absorção de energia de tendões de Aquiles de ratos. A exposição ao UST, modo contínuo, intensidade $0,5 \mathrm{~W} / \mathrm{cm}^{2}$, freqüência $1 \mathrm{MHz}$, subaquático, tempo de 5 minutos ao dia, diariamente por 9 dias consecutivos iniciado no $1^{\circ} \mathrm{PO}$, induziu a um aumento estatisticamente significante na força de tensão e resistência, além da capacidade de absorver energia dos tendões tratados em relação ao grupo placebo.

STEVENSON et al. (1986), estudaram o efeito do UST na recuperação funcional, força de tensão e formação de adesões no local cirúrgico em 77 tendões profundos do $3^{\circ}$ dedo das patas direitas de galinhas. Os animais foram divididos em 4 grupos: (A) sem tratamento, imobilização ou cirurgia, (B) apenas 4 semanas de imobilização, sem lesão, (C) tendões lesados e imobilizados por 4 semanas e (D) tendões lesados, imobilizados por 4 semanas e 20 dias seguintes de tratamento com UST, na freqüência de $3 \mathrm{MHz}$, intensidade 0,75 $\mathrm{W} / \mathrm{cm}^{2}, 5$ minutos e método subaquático. 
A análise dos resultados mostrou uma melhora significante da recuperação funcional e do reparo tecidual dos tendões flexores das patas de galinhas quando a aplicação do mesmo é imediatamente após 4 semanas de imobilização.

JACKSON et al. (1990), estudaram os efeitos da terapia com UST contínuo, subaquático, intensidade de $1,5 \mathrm{~W} / \mathrm{cm}^{2}$ diariamente nos primeiros 8 dias de PO e em dias alternados após este período, até completarem 21 dias de reparo tecidual de tendões de Aquiles de ratos. Os animais foram sacrificados 1 dia após o final do tratamento.

Foram pesquisadas diferentes etapas do tratamento: 2, 5, 9, 15 e 21 dias. Os resultados mostraram que todos os tratamentos a partir de 5 dias, apresentaram um aumento na síntese de colágeno no sítio da lesão e aumento da força de ruptura, quando comparados com os animais controle. Os dados suportam a hipótese de que o tratamento com UST aumenta a taxa de reparo de tendões de Aquiles de ratos e que há aumento na força de ruptura durante a cicatrização.

GAN, et al. (1995), estudaram os efeitos do tratamento com UST na cicatrização do tendão flexor de 76 galinhas White Leghorn hens, com 24 semanas de idade e $1,5 \mathrm{Kg}$ a 2,0 Kg. Foi provocada uma lesão no tendão flexor da falange proximal do terceiro dedo direito (região correspondente a zona 2 da mão humana) e os tendões lesados foram imobilizados com tala (splint) em uma angulação de $60^{\circ}$ de flexão de tornozelo e extensão da interfalangeana proximal.

Os animais foram subdivididos aleatoriamente em 3 grupos: grupo (A) controle sem tratamento, grupo (B) tratado com UST a partir do $7^{\circ}$ PO e o 
grupo (C) tratados com UST a partir do $42^{\circ} \mathrm{PO}$, nos seguintes parâmetros: freqüência de $3 \mathrm{MHz}$, intensidade de $0,8 \mathrm{~W} / \mathrm{cm}^{2}$ pulsado a $25 \%$ por 3 minutos cada sessão. Foram realizadas 10 sessões durante 10 dias consecutivos, método de acoplamento direto e ERA de $0,5 \mathrm{~cm}^{2}$.

Os resultados obtidos levaram em conta as análises da amplitude de movimento (ADM), força de tensão e análise histológica dos tendões, e revelaram uma diminuição do infiltrado inflamatório e cicatrização mais regular nos grupos tratados com UST, sendo mais pronunciado no grupo (B); um aumento de ADM estatisticamente comprovada no grupo (B) quando comparado com o grupo (A); quando comparou-se o grupo (B) com o grupo (C) houve uma diferença positiva para o grupo (B), porém não é estatisticamente significante.

ROBERTS et al. (1982), investigaram os efeitos do UST no reparo de tenorrafias de tendões flexores de coelhos. $\mathrm{O}$ tratamento era realizado por uma abertura no imobilizador de 7 coelhos tenotomizados onde aplicava-se o UST na intensidade $0,8 \mathrm{~W} / \mathrm{cm}^{2}$, modo pulsado, freqüência de $1 \mathrm{MHz}$, tempo de 5 minutos/dia, 5 dias/semana, por 6 semanas.

Os resultados não evidenciaram cicatrização dos tendões e concluíram que o tratamento afeta prejudicialmente o processo de cicatrização tendínea inicial quando comparados aos resultados do grupo controle (tenotomizados e imobilizados) e sugere mais pesquisas sobre o assunto.

TURNER et al. (1989), estudaram o efeito do UST na cicatrização de tendões reparados de frangos pós tenotomia. $O$ tratamento foi iniciado 7 dias após a lesão por uma abertura no imobilizador de gesso, o mesmo ocorreu para os animais do grupo placebo. 
Os parâmetros do UST usados para tratamento foram: freqüência de 3 $\mathrm{MHz}$, modo pulsado $1: 4$, intensidade de $1 \mathrm{~W} / \mathrm{cm}^{2}$, subaquático, por 4 minutos, 3 vezes por semana, por 5 semanas. A partir da $3^{\circ}$ semana as imobilizações foram retiradas e a movimentação livre foi permitida.

Os resultados não mostraram aumento significante na força e flexibilidade entre os grupos tratados e placebo (considerando um nível de 5\%).

\section{I.10 MICROSCOPIA DE POLARIZAÇÃO}

Por meio da microscopia de polarização é possível quantificar, com alta eficiência, as variações nos estados de agregação molecular, a ordem molecular, o momento de transição e a direção de vibração (VIDAL, 1987a, b).

O feixe de luz da microscopia de polarização vai incorrer num polarizador ideal Pol, onde será transmitido somente o seu componente com campo paralelo ao seu eixo de transmissão. Ainda há, neste tipo de microscopia, um segundo polarizador idêntico ao primeiro, o analisador An, com eixo de transmissão orientado verticalmente. Dessa maneira, a irradiância é máxima quando os eixos de transmissão entre o Pol e An é nulo, e mínima ou ausente quando essa angulação é de 90, segundo a Lei de Malus (FALK; et al., 1986).

A constituição básica do microscópio de luz polarizada é essencialmente dois filtros polarizadores: o Polarizador (Pol) e o Analisador (An) (VIDAL, 1987b). 
Sob o condensador do microscópio está posicionado o Pol. É possível, neste filtro polarizador, mobilização para ser situado ou afastado do trajeto da luz, além de uma rotação de $360^{\circ}$.

Já o An está localizado abaixo das oculares e sobre as objetivas. Deste modo, o plano de polarização do analisador se encontra perpendicular à direção de vibração da luz polarizada (com o vetor elétrico vibrante em um só plano) emitida, absorvendo-a; esse fenômeno ocorre pela própria natureza dos polarizadores.

Os polarizadores (Pol e An) são formados por placas de plástico laminado e coradas por iodo em solução ou por seu derivado de quinina, o qual se deposita na mesma direção das moléculas do polímero. Estas moléculas de polímeros são estiradas e orientadas na direção da força da laminação.

São estas características que irá fazer com que a placa polarizadora tenha todos os vetores elétricos da radiação visível absorvidos de forma seletiva, deixando transmitir apenas a energia radiante em uma direção, aquela que corresponde ao seu plano de polarização. Por causa disto, toda radiação polarizada perpendicularmente ao plano de polarização do analisador será absorvida e a intensidade de passagem de luz será máxima, quando o Pol e An estiverem paralelos entre si (VIDAL, 1987b).

A utilização de um microscópio de luz polarizada para examinar a organização e agregação das fibras de colágeno dos tendões e ligamentos está presente nos estudos de VIDAL (1966), MELLO et al. (1975), VIDAL et al. (1975), PIMENTEL (1981), VIDAL (1986), VIDAL \& CARVALHO (1990), WHITTAKER \& CANHAM (1991), VIDAL (1994) e VIDAL (1995a). 


\section{I.11 PROPRIEDADES ANISOTRÓPICAS ÓPTICAS}

A absorção seletiva da luz polarizada é um fenômeno anisotrópico óptico. Denominam-se como propriedades anisotrópicas ópticas a birrefringência e o dicroísmo linear. Essas duas faces de um mesmo fenômeno têm a mesma informação.

Em sistemas pouco orientados, muitas vezes é difícil detectar-se o dicroísmo linear, mas sim a birrefringência.

A anisotropia óptica está presente em muitas substâncias cristalinas (sólidos cujos átomos se distribuem de uma maneira regular), ou seja, as suas propriedades ópticas não são as mesmas em todas as direções numa mesma amostra (HECHT, 1991).

Com respeito ao índice de refração em um corpo isótropo, qualquer direção que a luz se propague nele, o fará com uma velocidade constante. Não sendo possível ocorrer em um corpo birrefringente, pois este possui dois índices de refração diferentes e conseqüentemente duas direções diferentes de propagação da luz (VIDAL, 1987b).

\section{I.11.1 BIRREFRINGÊNCIA DE MATERIAIS}

Birrefringência é a anisotropia óptica devida a propagação desigual da luz, em se tratando de velocidade, através de um objeto. Logo, o objeto tem diferentes índices de refração em determinadas direções, as quais são perpendiculares uma a outra no corpo birrefringente (VIDAL, 1987b). 
Ao examinar um material birrefringente entre filtros polarizadores com seus planos de polarização da luz, formando um ângulo de 90 graus, será apresentado um brilho quando uma de suas direções de propagação da luz formar um ângulo de 45 graus com seus planos de polarização da luz. Em outras palavras, através da microscopia de polarização, a luz polarizada ao incidir um objeto birrefringente e este se propagar em dois diferentes caminhos ópticos, sendo um na direção do raio ordinário $\left(\eta_{0}\right)$, e outro na direção do raio extraordinário $\left(\eta_{E}\right)$. Devido essa diferença de caminho óptico ou retardo ótico (OR), o material apresenta um brilho característico, cuja intensidade é máxima quando os seus eixos de propagação, correspondentes aos índices de refração, são colocados a $45^{\circ}$ dos dois filtros polarizadores do microscópio (VIDAL, 1987b; VIDAL \& CARVALHO, 1990). Este brilho será proporcional à espessura do objeto e à diferença de fase entre as frentes de luz emergentes do objeto.

Se os eixos de propagação do objeto estiverem paralelos ao An e ao Pol desaparecem as imagens birrefringentes, enegrecendo-se o objeto, é o que se chama de posição de extinção. Quando tal não acontece, permanecendo brilho em alguns setores do objeto, é porque existe material anisotrópico distribuído em outra direção que não aquela que foi extinta (VIDAL, 1987b).

Expressa-se quantitativamente a birrefringência em termos de retardos ópticos e usando nanômetros como unidades.

A birrefringência expressa-se pela equação: $B=\left(n_{O}-n_{E}\right)$ e o retardo óptico expressa-se pela equação: $O R=\left(n-n_{E}\right) \times t$, onde $t$ representa $a$ espessura do corpo.

Assim temos que: $\mathrm{OR}=\mathrm{B} \times \mathrm{t}$. 
Birrefringência de forma (BF) ou textural é o tipo de birrefringência do colágeno, ocorre devido a presença de microcorpos com morfologia assimétrica dispostas ordenadamente, de tal forma que seus diâmetros e distâncias sejam menores que o comprimento de onda $(\lambda)$, sendo dependente dos índices de refração, da contribuição dos volumes parciais das partículas e do meio homogêneo dispersante.

Segundo VIDAL (1987b) os feixes colágeno, além da BF, apresentam também uma birrefringência intrínseca positiva.

O volume parcial (concentração), a orientação e o estado de agregação das fibras de colágeno é o que caracteriza a BF.

Em princípio, a birrefringência intrínseca é determinada pela força orientacional de todas as transições eletrônicas na molécula (VILARTA \& VIDAL, 1989).

Alterações dos meios de imersão dos feixes de colágeno, em diferentes índices de refração $(\eta)$, permite estudar as suas propriedades ópticas como a birrefringência (VIDAL et al., 1975; MELO et al., 1975; VIDAL, 1987b). A imersão do colágeno nestes meios fará com que possa ser vista a variação de brilho deste, isto porque o valor da BF varia com o $\eta$ do meio de imersão.

A curva de birrefringência é determinada pela plotagem dos valores de retardo óptico (OR em nm) das fibras de colágeno em função do índice de refração médio dos fluidos de imersão, como a água destilada $(\eta=1,333)$; $20 \%, 30 \%, 40 \%, 60 \%, 80 \%, 100 \%$ de soluções de glicerina, cujos $\eta=1,3600$; 1,$3724 ; 1,3864 ; 1,4131 ; 1,4353$ e 1,4610 , respectivamente; e finalmente o Nujol $(\eta=1,4786)$. 
Fluidos que reagem com o tecido ou que não são capazes de penetrá-lo devem ser evitados, por essa razão a curva de BF do colágeno é registrada utilizando tais fluidos (MELO et al., 1975; VILARTA \& VIDAL, 1989; VIDAL \& CARVALHO, 1990).

Segundo VIDAL (1987b) é possível, de forma consistente e reprodutível, em água destilada, os feixes apresentarem os maiores valores de birrefringência, correspondendo aos valores da Birrefringência Total, isto é, representam os valores da BF somada à birrefringência intrínseca, e podem representar com objetividade a morfologia das moléculas de colágeno, o diâmetro e grau de empacotamento das fibras.

O aumento da birrefringência total está relacionado ao aumento de ligações cruzadas entre as fibrilas de colágeno, aumentando a cristalinidade e a agregação ordenada do colágeno tipo I. Isto foi demonstrado por VIDAL et al. (1975), onde modificações foram encontradas nas curvas de birrefringência, as quais foram relacionadas ao grau de agregação ordenada lateralmente das fibras. Diferença nos estados organizacionais de um mesmo tipo de colágeno podem ser encontradas em função da idade e da localização topográfica.

Conforme VILARTA \& VIDAL (1989), outro dado importante encontrado, foi o fato de que o exercício, ou seja, o estímulo mecânico provocado pela atuação do músculo sobre os tendões, levaria a uma melhor agregação das moléculas de colágeno, e conseqüentemente um melhor desempenho mecânico nestes tendões.

De acordo com PIMENTEL (1981) quando nos encontramos frente a diferentes processos fisiológicos, pode-se conseguir maiores informações sobre os aspectos de birrefringência da molécula do colágeno, apesar do 
conhecimento já existente. Um exemplo disto seria no processo fisiológico de reparo tecidual.

Já é conhecido o padrão de reparação desenvolvido pelo tendão, quando estudado pelo método de análise da birrefringência (MELLO et al., 1975). Comprovação deste método de estudo para diferentes situações funcionais e tecidos, sob intervenção de métodos físicos também se configura no trabalho de WHITTAKER \& CANHAM (1991), mostrando que além da análise qualitativa, pode-se quantificar o fenômeno ligado a organização molecular do colágeno. 


\section{OBJETIVO}

O objetivo deste estudo foi determinar a eficácia da fonoforese, do ultrasom terapêutico e da aplicação tópica de hidrocortisona no tratamento do tendão de rato em processo de reparo tecidual.

Para isso, foi proposto um estudo comparativo destas modalidades terapêuticas, e do efeito destes tratamentos no processo de reparo tecidual, por meio das análises do volume parcial (concentração), estado de agregação e orientação das fibras de colágeno, através da propriedade anisotrópica Birrefringência. 


\section{MATERIAIS E MÉTODOS}

\section{III.1 ANIMAIS DE EXPERIMENTAÇÃO}

Neste trabalho experimental foram selecionados 40 ratos (Rattus Novergicus, Albinus) machos, saudáveis e sedentários, da linhagem Wistar, com 90 dias de idade e massa corporal variando de 200 a 250 gramas.

Os animais provenientes do Biotério Central da Universidade Federal de São Carlos (UFSCar) foram mantidos em gaiolas apropriadas de polietileno padrão, em grupos com 4 animais por gaiola, no Biotério do Laboratório de Eletrotermofototerapia da UFSCar e mantidos pelo menos 48 horas no novo ambiente, para aclimatação, com condições ambientais controladas (12 horas de ciclo claro/escuro; ambiente higienizado; temperatura e ventilação adequadas) antes, durante e após os procedimentos experimentais, com livre acesso à água e alimentação.

\section{III.2 AGRUPAMENTO}

Os 40 animais foram distribuídos aleatoriamente em 5 grupos, sendo os grupos I e II controle e os grupos III, IV e V experimentais, os quais possuíam 8 animais cada. Veja a seguir como os animais ficaram submetidos após o agrupamento:

Grupos Controle

GRUPO I (Gl): $(n=8)$ os animais deste grupo não sofreram lesão e não receberam nenhum tipo de tratamento, por isso, os tendões destes animais 
desenvolveram-se normalmente durante o período experimental. Este é um tipo de controle chamado de padrão.

GRUPO II (GIl): $(n=8)$ os tendões destes animais foram seccionados por tenotomia total e durante o processo de reparo do tendão, receberam um tratamento placebo por 300 segundos com gel estéril e equipamento de UST desligado, ou seja, os tendões dos animais deste grupo tiveram um processo de reparo tecidual de curso normal, sem interferências externas, porém houve o estresse da simulação do tratamento.

$>$ Grupos Experimentais

GRUPO III (GIII): $(n=8)$ durante 300 segundos, os animais deste grupo, receberam, de um UST desligado, tratamento de aplicação tópica, com gel estéril contendo uma concentração de $10 \%$ de hidrocortisona.

GRUPO IV (GIV): $(n=8)$ aplicação do UST como forma de tratamento, na modalidade pulsada à $100 \mathrm{~Hz}$ e regime de 1:4 (2 ms ON e 8 ms OFF - 20\%), com gel estéril comum servindo de meio de acoplamento.

GRUPO V $(\mathrm{GV}):(\mathrm{n}=8)$ tratamento por fonoforese, utilizando um equipamento de UST na modalidade pulsada à $100 \mathrm{~Hz}$ e regime de $1: 4(2 \mathrm{~ms}$ ON e $8 \mathrm{~ms}$ OFF - 20\%), com gel estéril contendo uma concentração de $10 \%$ de hidrocortisona. 
Os animais dos grupos lesados não receberam nenhum tipo de imobilização, ou seja, foi permitido suporte de peso pós-cirúrgico. Pois, em um experimento realizado por ENWEMEKA (1992), tendões tenotomizados que foram submetidos à carga funcional no $5^{\circ}$ do pós-operatório, mostraram maior área de secção transversa devida ao maior número de fibras colágenas depositadas no eixo longitudinal do tendão.

A intensidade do UST foi definida através de estudos como os de CUNHA et al. (2001), GAN et al. (1995), ENWEMEKA et al. (1990), ENWEMEKA (1989b), DYSON \& SMALEY (1983) e DYSON et al. (1968) que sugerem a utilização de baixas intensidades no tratamento com UST.

A modalidade pulsada à $100 \mathrm{~Hz}$, no regime de 1:4 (20\%), é a mais utilizada na prática clínica fisioterápica e por isso foi a escolhida (DOCKER, 1987; MCDIARMID \& BURNS, 1987; CUNHA et al., 2001).

Os animais dos grupos experimentais após terem os seus tendões seccionados por tenotomia total, foram tratados a partir do $1^{\circ} \mathrm{PO}$ (pósoperatório) por um UST com as seguintes características: ERA de $0,5 \mathrm{~cm}^{2}$, freqüência de $1 \mathrm{MHz}$, intensidade de $0,5 \mathrm{~W} / \mathrm{cm}^{2}$ (média temporal e espacial SATA), com um tempo de 300 segundos cada sessão.

O agente acoplador eleito foi o gel, utilizado entre o transdutor e a pele dos animais, a fim de excluir o ar entre as interfaces, evitando assim a reflexão da onda ultra-sônica (WILLIANS, 1987; CASAROTTO, 2000). 


\section{III.3 O APARELHO DE UST}

O equipamento de UST utilizado é da empresa Bioset, modelo SONACEL EXPERT, que será de uso exclusivo para a realização deste experimento.

\section{III.4 MODELO EXPERIMENTAL}

O modelo usado neste estudo foi baseado nos trabalhos de CUNHA et al. (2001); REDDY et al. (2001); ENWEMEKA \& REDDY (2000); REDDY et al. (1998a, b); STEHNO-BITTEL, (1998); GUN et al. (1997); ENWEMEKA, (1991a, b); ENWEMEKA et al. (1990); ENWEMEKA, (1989b); ENWEMEKA, (1988), ao promoverem uma tenotomia total na porção média do tendão calcanear de animais através de uma incisão transversal do tendão dissecado.

\section{III.5 PROCEDIMENTO CIRÚRGICO}

Antes de ocorrer à cirurgia os animais do grupo II, III, IV e V foram pesados. Em seguida, anestesiados por injeção intramuscular de anestésico Ketamina (Francotar®- $10 \mathrm{ml}$ - uso veterinário. Virbac do Brasil Ind. Com Ltda), na dosagem de 0,08 $\mathrm{ml}$ para cada $100 \mathrm{~g}$ de peso corpóreo, associado ao relaxante muscular e analgésico Cloridrato de Xylazina (Virbaxy|® 2\%- $10 \mathrm{ml}$ uso veterinário. Virbac do Brasil Ind. Com Ltda.) na dosagem de 0,04 $\mathrm{ml}$ para cada $100 \mathrm{~g}$ de peso corpóreo. Para isso, foi utilizado uma seringa de insulina (1 $\mathrm{ml})$. 
A próxima etapa foi depilar e limpar a pele ao redor do tendão de Aquiles da pata direita. Através de uma pequena incisão sobre a pele, o tendão direito foi liberado e tenotomizado transversalmente na região medial, entre a inserção calcanear e a junção miotendínea.

Por fim, somente a pele foi suturada com fio de sutura categute 4.0 , não reabsorvível e então limpa com solução de álcool iodado, a fim de propiciar a higienização e evitar infecções no local.

Após o procedimento cirúrgico, os animais foram submetidos a profilaxia antimicrobiana, foi administrado intraperitonialmente em dose única CEFAZOLINA (20mg/100g de peso corporal). Retornando-os nas gaiolas, para recuperação da anestesia.
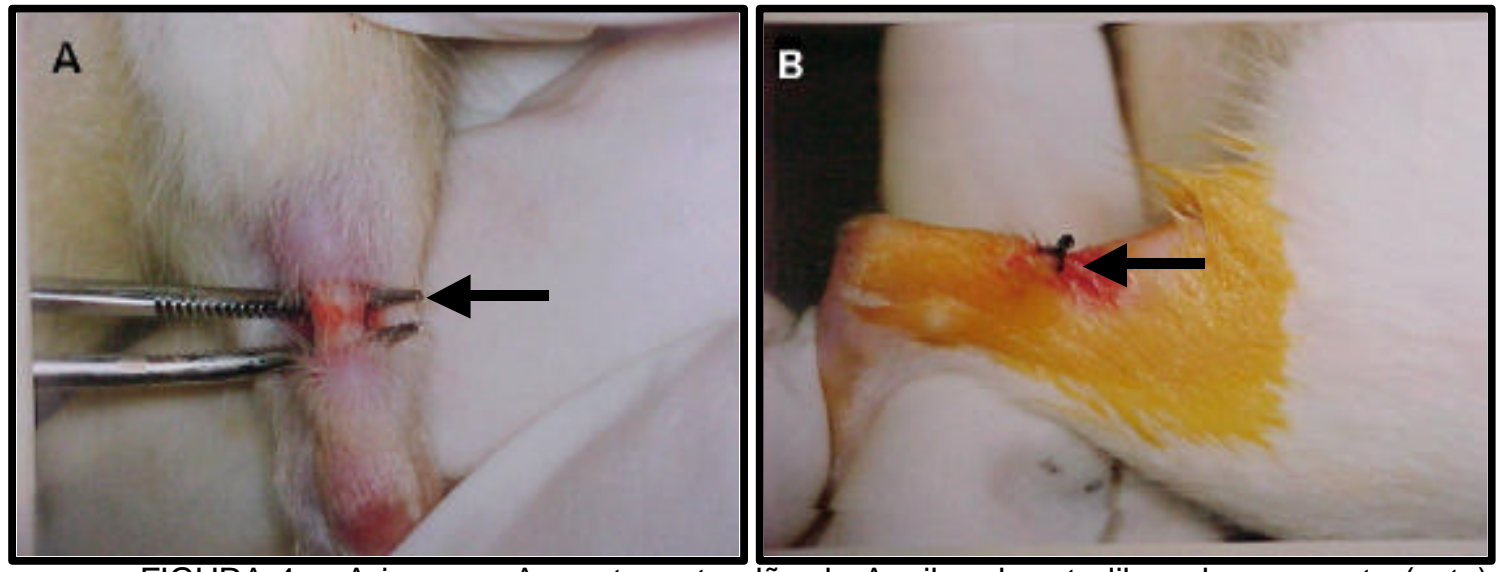

FIGURA 4 - A imagem A mostra o tendão de Aquiles do rato liberado e exposto (seta) para a realização da tenotomia. $\mathrm{Na}$ imagem $\mathrm{B}$ temos a pele suturada, após o procedimento cirúrgico. Notar a presença de solução de álcool iodado (seta) no local cirúrgico.

\section{III.6 PROCEDIMENTO EXPERIMENTAL}

O equipamento de UST foi aferido antes de iniciar o experimento, com o propósito de certificação e confirmação das doses propostas, ou seja, obter uma alta confiabilidade na intensidade efetiva de emissão. A aferição foi realizada no Laboratório de Ultra-som da Bioengenharia na Universidade de São Paulo (USP) - Campus São Carlos. 
O procedimento experimental foi sempre realizado no período da manhã.

As manipulações com os animais eram, à medida do possível, iguais a todos.

Antes de executar os respectivos tratamentos, os animais dos grupos II, III, IV e V eram sedados por inalação de éter etílico, para introdução destes na gaiola de contenção de animais (ilustrado abaixo), permitindo manipulação mais segura e precisa da pata (CUNHA, 2001).
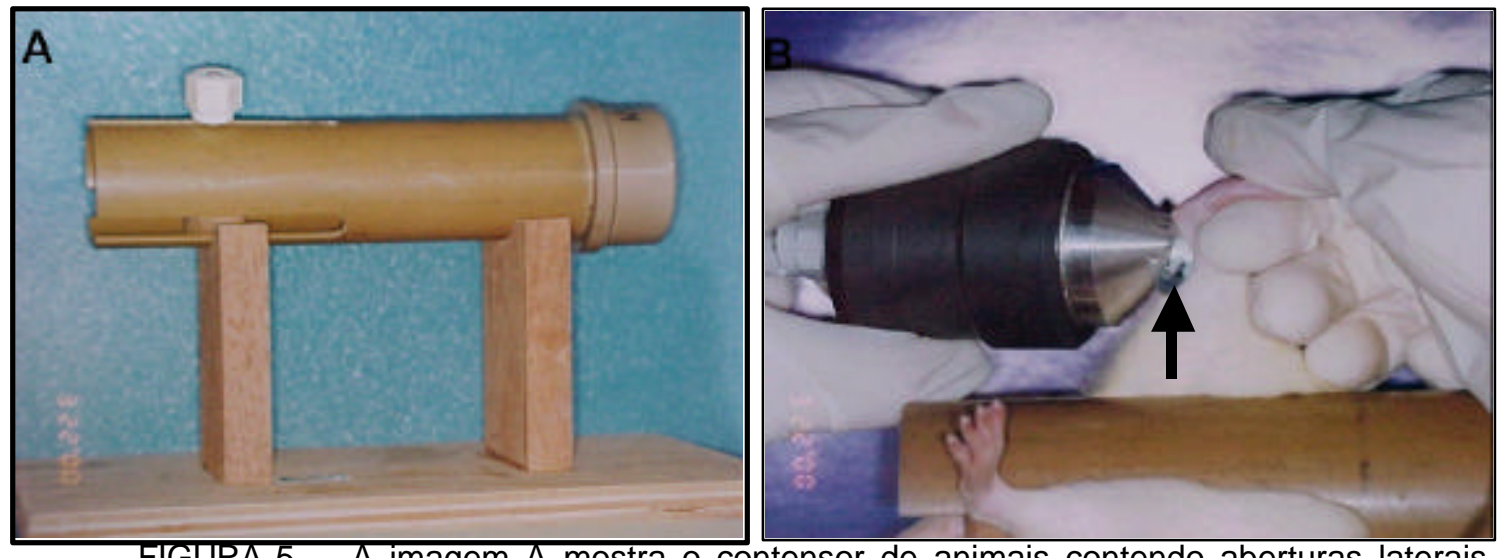

FIGURA 5 - A imagem A mostra o contensor de animais contendo aberturas laterais para as patas dos ratos possibilitando o tratamento com ultra-som terapêutico (UST). A imagem $\mathrm{B}$ mostra o rato contido e submetido à sessão de tratamento com UST. Notar a quantidade de gel (seta) colocado para facilitar o acoplamento do cabeçote com ERA de $0,5 \mathrm{~cm}^{2}$.

Durante todos os dias de experimento, os animais do grupo I permaneceram em suas gaiolas.

A aplicação do UST foi na pata traseira direita de forma direta, com o gel servindo de meio de acoplamento, sobre a região do tendão (sempre depilada e limpa), a partir do $1^{\circ}$ pós-operatório (PO). Para facilitar a realização das aplicações do UST na região do tendão calcâneo foi necessário utilizar uma ERA ajustada ao tamanho da estrutura a ser tratada (FIGURA 6), permitindo um melhor contato, bom direcionamento, maior precisão do tratamento e evitando perdas de energia. Para assegurarmos um tratamento mais seguro e uniforme da área, procuramos manter a cabeça de tratamento em pequenos 
movimentos lentos, circulares, contínuos e uniformes, conhecido como método dinâmico (HOOGLAND, 1986).

FIGURA 6 - Imagem mostrando o cabeçote com ERA reduzida (seta) de $0,5 \mathrm{~cm}^{2}$ utilizado no tratamento.

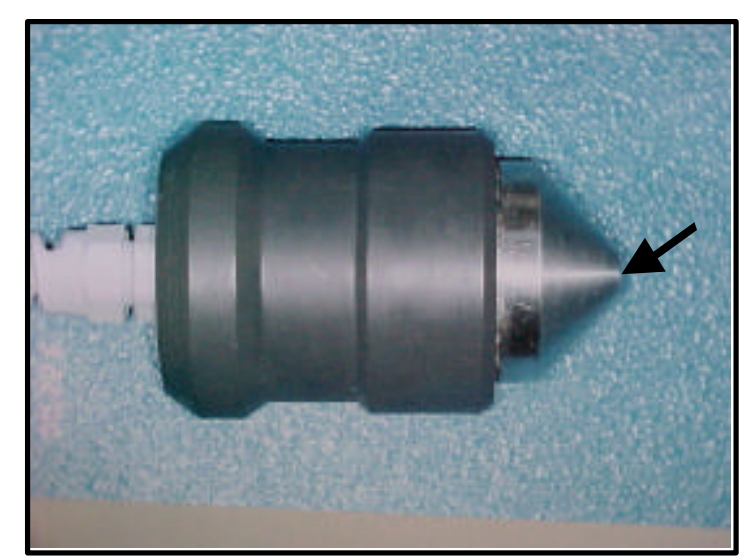

Foram 10 sessões de tratamento, durante 12 dias, ou seja, houve um intervalo de 2 dias após 5 sessões consecutivas, e a seguir mais 5 consecutivas eram realizadas, simulando a rotina de aplicações em clínica de fisioterapia (CUNHA, 2001).

Dias de aplicação do UST

$\begin{array}{cccc}\text { Dia } 0 & \text { Dia } 1 & \text { Dia } 12 & \text { Dia } 13 \\ \text { cirurgia } & 1^{\circ} \text { aplicação } \\ & \text { do UST } & 12^{\circ} \text { aplicação sacrifício } \\ \text { do UST }\end{array}$

FIGURA 7 - Esquema dos grupos que receberão radiação laser.

Após serem tratados, os animais voltavam as gaiolas de origem. 


\section{III.7 SACRIFÍCIO DOS ANIMAIS}

Os animais foram mortos no $13^{\circ}$ pós-operatório, através da inalação excessiva de éter sulfúrico e seus tendões direitos foram removidos cirurgicamente como um todo, desde a inserção calcanear até a junção miotendínea, por dissecção. Imediatamente os tendões foram lavados em solução salina a $0.9 \%$. Em seguida, os tendões foram colocados em solução de formol a $10 \%$ para fixação.

\section{III.8 PREPARAÇÃO DAS LÂMINAS HISTOLÓGICAS}

As peças permaneceram por 24 horas no fixador. Depois disso, as peças, foram lavadas por 24 horas em água corrente. Logo em seguida, passaram por desidratação em soluções crescentes de álcool etílico, a 70\%, $90 \%, 95 \%$ por 1 hora em cada solução e a 100\%, sendo este repetido por 3 vezes de 1 hora cada. Após os banhos de desidratação as peças iniciaram a diafanização em solução de álcool/xilol 1:1 por 1 hora e a seguir em 3 banhos de xilol puro; a duração de cada banho foi de 1 hora.

As peças foram retirados do xilol e colocados imediatamente em parafina líquida $\left(60^{\circ} \mathrm{C}\right)$, onde se submeteram em 3 banhos de parafina líquida por uma hora cada banho. Após isso, finalmente, a inclusão em blocos de parafina, para o procedimento do corte das peças.

As peças, inclusos nos blocos de parafina, foram cortados longitudinalmente por meio de um micrótomo "820" SPENCER - American Optical Corporation, do Departamento de Hidrobiologia da UFSCar com 
espessura padronizada de $7 \mu \mathrm{m}$, buscando melhor visão para análise. Os cortes foram então montados em lâminas histológicas sem cobertura por lamínulas e/ou coloração.

Cada lâmina histológica foi montada com uma série de no mínimo 5 cortes consecutivos de cada peça e cada grupo de animais foi representado por 8 lâminas histológicas montadas com seus respectivos tendões.

Após serem montadas, todas as lâminas foram desparafinizadas, e hidratadas novamente.

\section{III.9 MEDIDAS DE BIRREFRINGÊNCIA}

Para serem analisadas, as lâminas histológicas foram tomadas ao acaso, sendo classificadas por código, de modo a não se identificar, no momento das medidas de birrefringência, a que animal correspondiam.

A análise das fibras de colágeno foram realizadas utilizando para isso uma de suas propriedades anisotrópicas ópticas - a birrefringência de forma ou textural, através da microscopia de polarização.

Para a efetivação da análise de birrefringência total as lâminas histológicas de cada grupo, foram imersas por 30 minutos em água destilada, cujo índice de refração é de $(\eta=1.333)$, em referência aos estudos de VIDAL (1987b). As medidas dos retardos ópticos (OR em nm) em H2O representam a soma da birrefringências intrínsecas e textural dos feixes de colágeno.

Após o período de imersão, as lâminas foram cobertas por lamínulas, contendo água destilada nas interfaces. 
As medidas de OR, foram obtidas pela microscopia de luz polarizada no microscópio Zeiss, com uma objetiva Pol 10x/0,22, condensador 0,0, compensador Sénarmont's $\lambda / .4$, luz monocromática $\lambda=546 \mathrm{~nm}$, obtida por meio de um filtro de interferência Zeiss; no Laboratório de Biologia Celular, da Universidade Estadual de Campinas UNICAMP, sob a orientação do Prof. Dr. Benedicto de Campos Vidal, que se presta à investigação da matriz extracelular por meio da microscopia de polarização.

Para realização das medidas, o eixo longo do tendão foi orientado a aproximadamente $45^{\circ}$ em relação aos polarizadores do microscópio. É conhecido que nesta posição as fibras de colágeno exibem o maior brilho e conseqüentemente um alto valor de OR, desta forma, as medidas foram realizadas nas fibras posicionadas predominantemente paralelas ao eixo longo do tendão, e representam o OR exibido nos diferentes grupos.

Foram realizadas 80 medidas de OR, em diferentes pontos das regiões centrais dos tendões, região da lesão por tenotomia total, para cada grupo estudado.

\section{III.10 ANÁLISE ESTATÍSTICA}

\section{III.10.1 ANÁLISE DESCRITIVA}

Os dados obtidos, segundo os procedimentos já descritos acima, estão organizados na tabela abaixo, onde quanto menores forem os valores numéricos observados de birrefringência piores serão os resultados do tratamento. 
TABELA 1 - Dados observados nos cinco grupos analisados e suas medidas descritivas em relação aos valores de birrefringência.

\begin{tabular}{|c|ccccc|}
\hline Rato & Grupo I & Grupo II & Grupo III & Grupo IV & Grupo V \\
\hline $\mathbf{1}$ & 57.9336 & 15.6348 & 14.9076 & 21.6342 & 24.1491 \\
$\mathbf{2}$ & 61.1454 & 16.7256 & 16.5135 & 21.816 & 26.2398 \\
$\mathbf{3}$ & 55.449 & 17.1195 & 18.5739 & 25.4217 & 28.6638 \\
$\mathbf{4}$ & 57.2064 & 17.3619 & 16.2408 & 22.9977 & 27.4215 \\
$\mathbf{5}$ & 57.6609 & 16.6953 & 15.5136 & 23.0886 & 29.1789 \\
$\mathbf{6}$ & 57.9942 & 16.9983 & 15.8772 & 23.9976 & 28.4214 \\
$\mathbf{7}$ & 58.2972 & 16.665 & 17.0286 & 21.0888 & 23.9067 \\
$\mathbf{8}$ & 57.6306 & 16.7862 & 16.4226 & 19.9677 & 25.3611 \\
\hline Média & 57.915 & 16.748 & 16.385 & 22.502 & 23.668 \\
Mediana & 57.797 & 16.756 & 16.332 & 22.407 & 26.831 \\
Máximo & 61.145 & 17.362 & 18.574 & 25.422 & 29.179 \\
Mínimo & 55.449 & 15.635 & 14.908 & 19.968 & 23.907 \\
Amplitude & 5.696 & 1.727 & 3.666 & 5.454 & 5.272 \\
Variância & 2.474 & 0.261 & 1.206 & 3.000 & 4.256 \\
DP & 1.573 & 0.511 & 1.098 & 1.732 & 2.063 \\
\hline
\end{tabular}

Através desta tabela nota-se que os maiores valores de birrefringência pertence ao Grupo I, no qual não houve lesão, isto pode ser verificado observando as medidas de posição (média, mediana, máximo e mínimo).

Pode-se observar que a média e a mediana do Grupo II são bem próximas daquelas observadas no Grupo III; estes dois grupos apresentam as menores medidas de posição sendo elas as que mais se distanciam das observadas no Grupo I.

Os Grupos IV e V tem suas medias próximas, mas o mesmo não ocorre quando comparamos suas medianas. Esses dois grupos, principalmente o Grupo V, são os que apresentam essas medidas mais próximas das 
observadas no Grupo I (grupo que não sofreu lesão), entretanto mesmo para esses dois grupos as diferenças em relação às medidas do Grupo I são muito grandes.

O Grupo II é o que apresenta a menor variabilidade, seguido pelo grupo III, ou seja, seus valores são os que menos se distanciam das suas respectivas médias. Já o Grupo V apresenta a maior variância, indicando com isso que existe uma maior dispersão dos dados em torno da sua média, em relação aos demais.

Através da figura que se encontra a seguir, se tem à informação da tabela 1 na forma gráfica. Pode-se observar mais nitidamente que o Grupo I possui os valores mais elevados da medida de birrefringência e que o Grupo V é o que mais se aproxima dele, mas mesmo assim fica à uma grande distância (a mediana e a média do Grupo I são pelo menos o dobro da mediana e da médias de todos os outros grupos, respectivamente). 


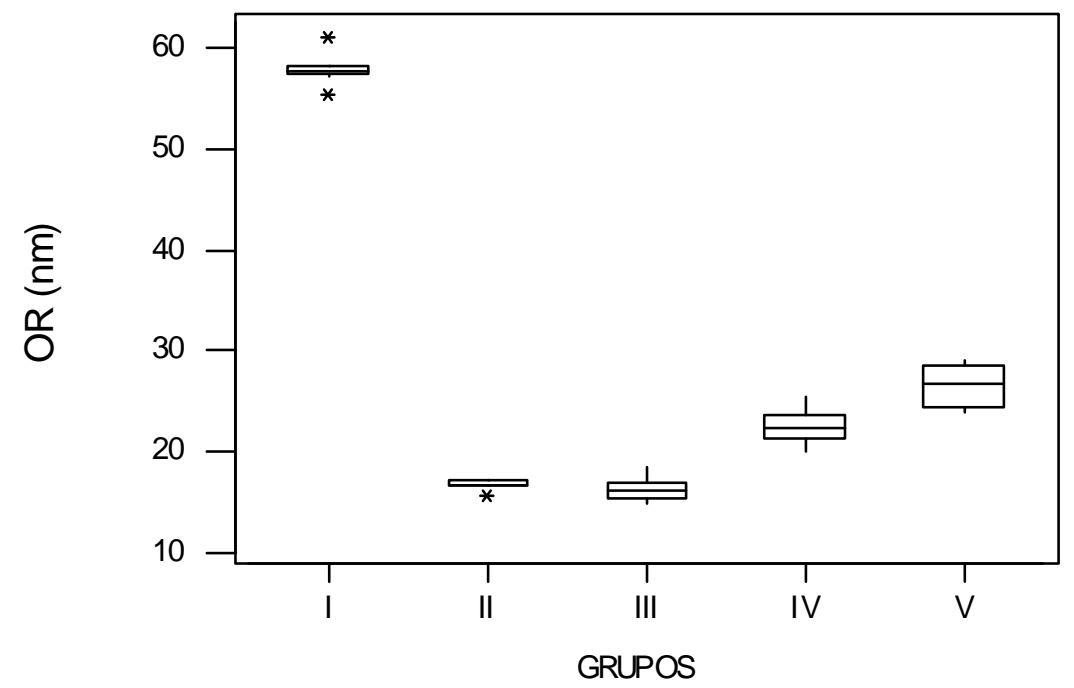

FIGURA 8 - Distribuições das medições de birrefringência

Observando o gráfico percebemos mais nitidamente que os valores de birrefringência estão mais dispersos no grupo $V$ e mais compactados no Grupo II. Apenas nos Grupos I e II encontramos pontos discrepantes.

Como o Grupo I apresentam valores de birrefringência bem maior que os demais, foi feito um Box-plot (FIGURA 9) apenas com os Grupos II, III, IV e $\checkmark$ para poder visualiza-los melhor. 


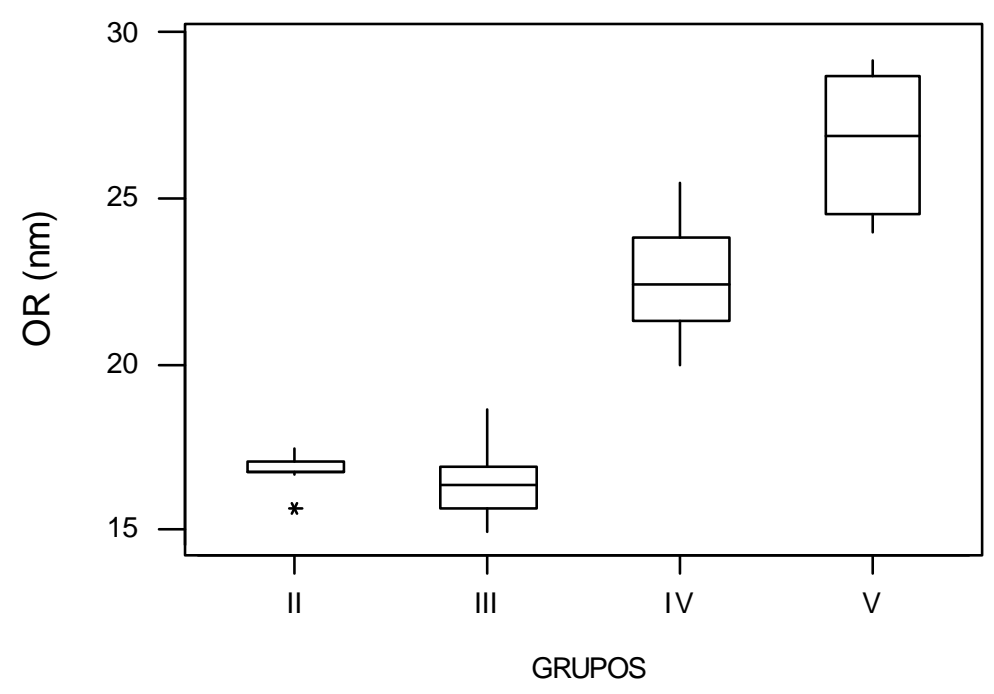

FIGURA 9 - Distribuições das medições de birrefringência excluindo o Grupo I

Através dessa figura algumas características destes grupos ficam mais claras, podemos perceber mais nitidamente que os Grupos II e III são mais parecidos entre si com relação à medida de birrefringência, sendo que a variabilidade do Grupo II é menor. Além disso, temos uma visão melhor da diferença dos valores de birrefringência nestes dois grupos comparados com os demais.

Também fica mais nítido a maior variabilidade existentes no Grupo V aonde temos os maiores valores de birrefringência quando comparado com os demais (não incluindo o Grupo I). 


\section{III.10.2 COMPARACÃO ESTATÍSTICA ENTRE OS 5 GRUPOS}

\section{ESTUDADOS}

Para uma comparação estatística mais rigorosa dos cinco grupos estudados torna-se necessário à aplicação de métodos estatísticos como, por exemplo, um teste paramétrico apropriado como uma análise de variância (ANOVA) paramétrica. Mas, em geral, a validade dos resultados obtidos por essas técnicas está condicionada à satisfação de condições como homocedasticidade (isto é, deve haver homogeneidade nas variâncias dos grupos), o que, segundo o teste feito (em anexo A) não ocorre aqui. Então, a alternativas é a utilização de métodos não paramétricos equivalentes (como os baseados em postos das observações), os quais são mais robustos que os seus correspondentes paramétricos sob violação dessas condições.

Como deveriam ser comparados cinco grupos independentes, isto é, cinco grupos cujos tendões pertenciam a diferentes ratos foi utilizado o teste não paramétrico de Kruskal-Wallis (CONOVER, 1980).

O teste de Kruskal-Wallis compara a igualdade das distribuições de duas ou mais populações, nesse trabalho, as hipóteses a serem testadas são:

$\mathrm{H}_{0}$ : Todos os cinco grupos apresentam funções de distribuição idênticas (igualdade das populações em relação a medidas de birrefringência); 
$H_{a}$ : pelo menos um grupo apresenta função de distribuição distinta (pelo menos uma das populações estudada é diferente em relação a medidas de birrefringência).

Como descrito anteriormente este teste foi aplicado (em anexo B) considerando como medida de cada rato a média das dez observações feitas. Os resultados são resumidos na tabela a seguir.

TABELA 2 - Resultados do teste de Kruskal-Wallis para a verificação da diferença entre os grupos estudados.

estatística teste

35.50976 p valor

0.0000

Observa-se que o teste rejeitou a igualdade entre os grupos a um nível de significância menor que $0.01 \% \quad(p<0.0001)$ em relação aos valores observados de birrefringência. Portanto deve-se identificar, por meio de um teste adequado de comparações múltiplas, quais grupos diferem entre si. 


\section{RESULTADOS}

A seguir, serão apresentados os resultados relativos à análise de Birrefringência Total.

As observações qualitativas serão apresentadas por meio de fotomicrografias das imagens dos tendões, visualizadas ao microscópio de luz polarizada.

A representação quantitativa será por meio dos valores de Retardo Óptico OR (em nm).

\section{IV.1 ANÁLISE QUALITATIVA}

$\mathrm{Na}$ figura 10 dos grupos I, II, III, IV e V, podemos observar a concentração, o estado de agregação, a orientação e a deposição das fibras de colágeno no local da tenotomia por meio da microscopia de luz polarizada, além da morfologia do crimp e do brilho característico.

As imagens da esquerda (A, C, E, G e I) correspondem as observações do alinhamento do eixo longo dos tendões em aproximadamente $45^{\circ}$ em relação aos polarizadores.

As imagens da direita (B, D, F, H e J) correspondem as observações de alinhamento do eixo longo dos tendões com 0 polarizador em aproximadamente zero graus em relação ao analisador.

As imagens A e B refere-se aos tendões dos animais do grupo controle sem lesão.

As imagens $C$ e $D$ refere-se aos tendões dos animais do grupo com lesão e tratamento placebo. 
As imagens $E$ e $F$ refere-se aos tendões dos animais do grupo experimental tratado com aplicação tópica de hidrocortisona.

As imagens $\mathrm{G}$ e $\mathrm{H}$ refere-se aos tendões dos animais do grupo experimental tratado com ultra-som terapêutico.

As imagens $\mathrm{I}$ e $\mathrm{J}$ refere-se aos tendões dos animais do grupo experimental tratado com fonoforese.

Podemos observar nas regiões dos tendões demarcadas por seta um alto brilho de birrefringência. Já na imagem $A$, em toda extensão do tendão se apresenta o alto brilho de birrefringência. As imagens $C$ e $E$ são as que apresentam menor extensão de alto brilho de birrefringência.

O tratamento com fonoforese (imagem I) é o que favoreceu, dentre os experimentais, a maior extensão de alto brilho de birrefringência.

Podemos observar nas imagens $\mathrm{B}, \mathrm{D}, \mathrm{F}, \mathrm{H}$ e $\mathrm{J}$ a morfologia do crimp com diferenças nas dimensões das fibras e periodicidade das ondulações entre os grupos. Essas diferenças são mais evidentes quando se compara a imagem B (observamos bastante crimp) em relação à imagem $D$ e $F$ (observamos pouco crimp). Entre a imagem D e F não se percebe diferenças.

As diferenças da morfologia do crimp da imagem B comparada com as imagens $\mathrm{H}$ e $\mathrm{J}$ é menor. A morfologia do crimp da imagem $\mathrm{J}$ é a que mais se parece com a da imagem B.

A imagem A mostra com nitidez o paralelismo (estrela) das fibras de colágeno no tendão, o qual não pode ser observado na imagem C e E. Já nas imagens G e I o paralelismo é observado com moderada nitidez.

Ao comparamos as imagens das modalidades de tratamento entre eles, podemos visualizar uma melhor concentração, estado de agregação, 
orientação e deposição das fibras de colágeno no local da tenotomia, nas imagens dos tendões tratados com fonoforese, quando comparados com as imagens de tendões dos demais grupos que receberam tratamento. Porém, uma menor organização é percebida se comparados com o grupo controle sem lesão.

Nos tendões tratados com UST a concentração, estado de agregação, orientação e a deposição das fibras de colágeno no local da tenotomia, se mostram um pouco diminuídas, quando comparados com os tendões tratados fonoforese, no entanto, mostrando-se melhor que os tendões tratados com aplicação tópica de hidrocortisona.

Nas imagens dos tendões dos animais tratados com aplicação tópica de hidrocortisona, não observamos diferença, quando comparado ao tendões do grupo controle lesados sem tratamento, ou seja, uma pobre orientação e agregação das fibras de colágeno. 
$45^{\circ}$
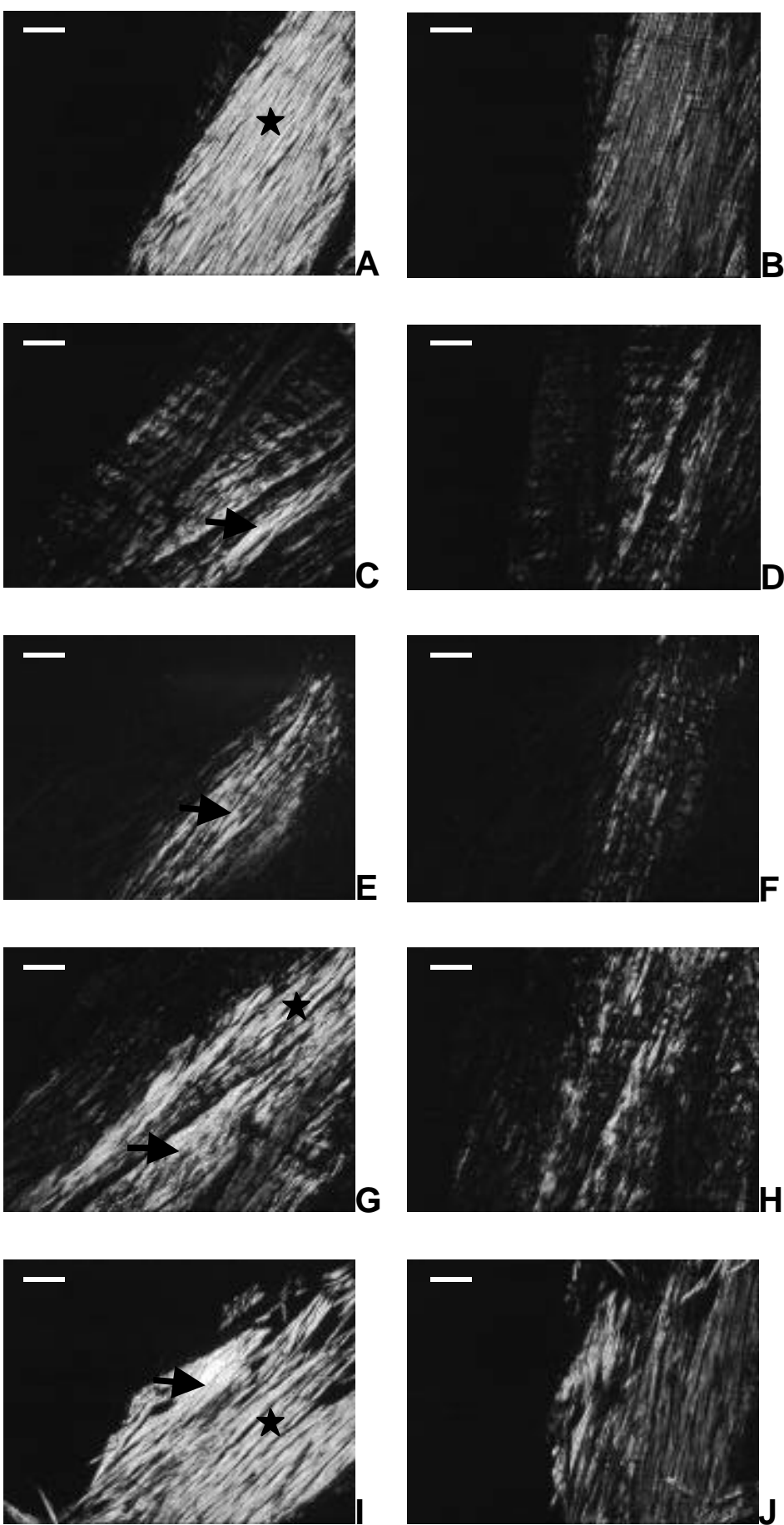

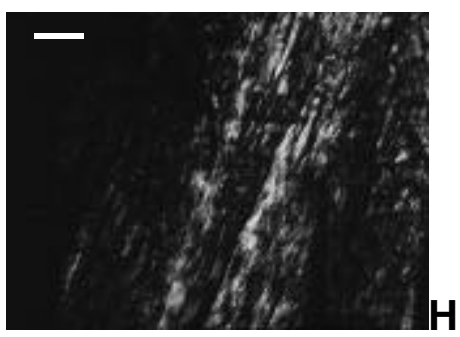

Zero Graus
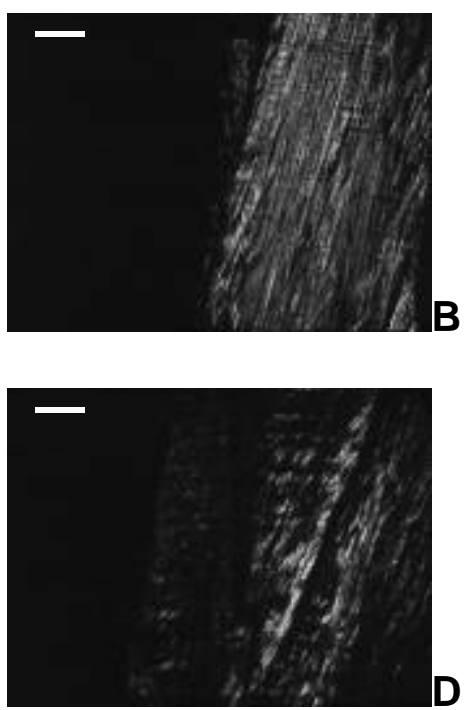

Grupo II

Grupo III

Grupo IV

Grupo V

FIGURA 10 - Imagens referentes às observações qualitativas da análise de birrefringência total por meio de microscopia de luz polarizada dos tendões. As imagens $A, C$, $E, G$ e I estão alinhadas em aproximadamente $45^{\circ}$ entre o polarizador e 0 analisador. As imagens $\mathrm{B}, \mathrm{D}, \mathrm{F}, \mathrm{H}$ e $\mathrm{J}$ correspondem as observações do alinhamento do eixo longo dos tendões com o polarizador em aproximadamente $\sigma$, onde mostram a morfologia do crimp. A estrela mostra o paralelismo entre as fibras colágenas e a seta, áreas com alto brilho de birrefringência. A barra corresponde a $200 \mu \mathrm{m}$. 


\section{GRUPO I}

\section{$45^{\circ}$}

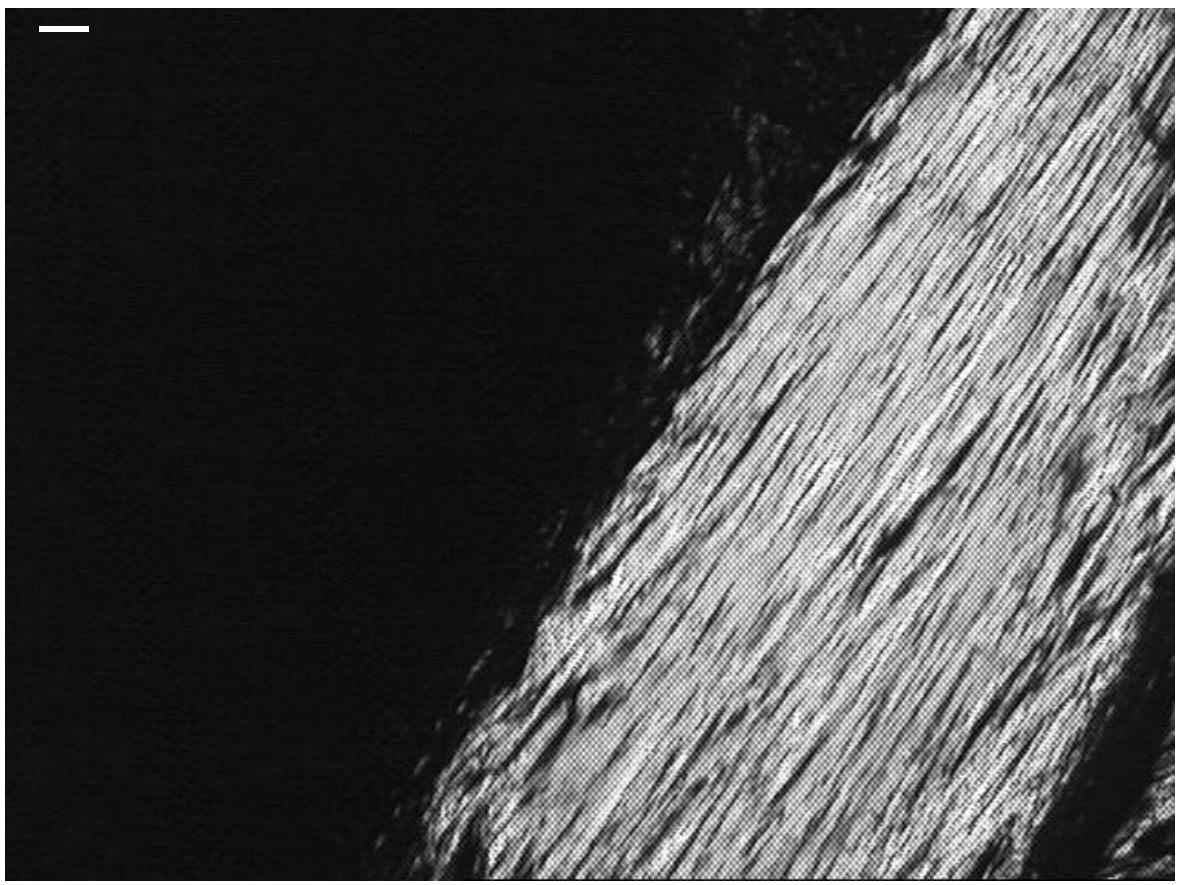

\section{ZERO GRAUS}

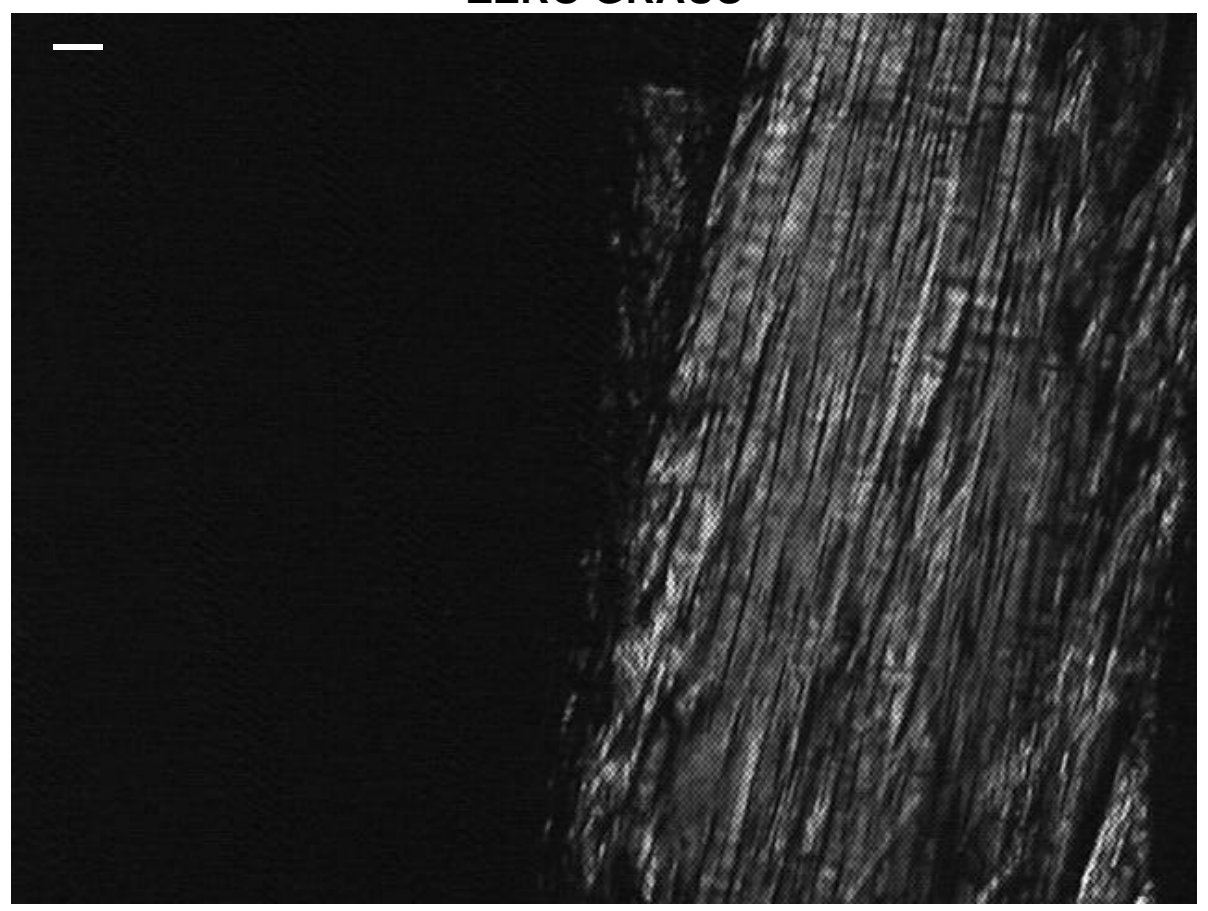

FIGURA 11 - Imagens referentes às observações qualitativas da análise de birrefringência total por meio de microscopia de luz polarizada dos tendões que não sofreram lesão e nem tratamento. A barra corresponde a $200 \mu \mathrm{m}$. 
GRUPO II

$45^{\circ}$

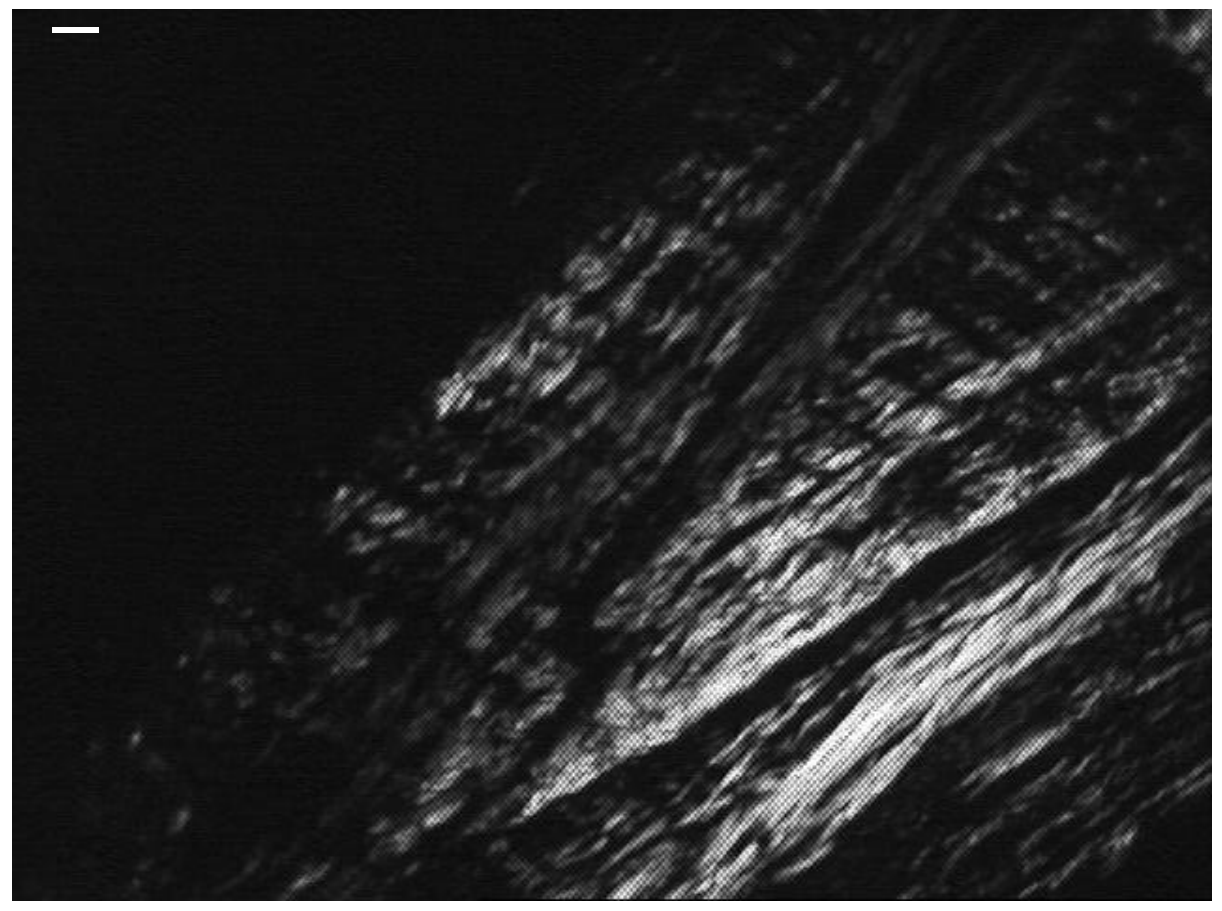

ZERO GRAUS

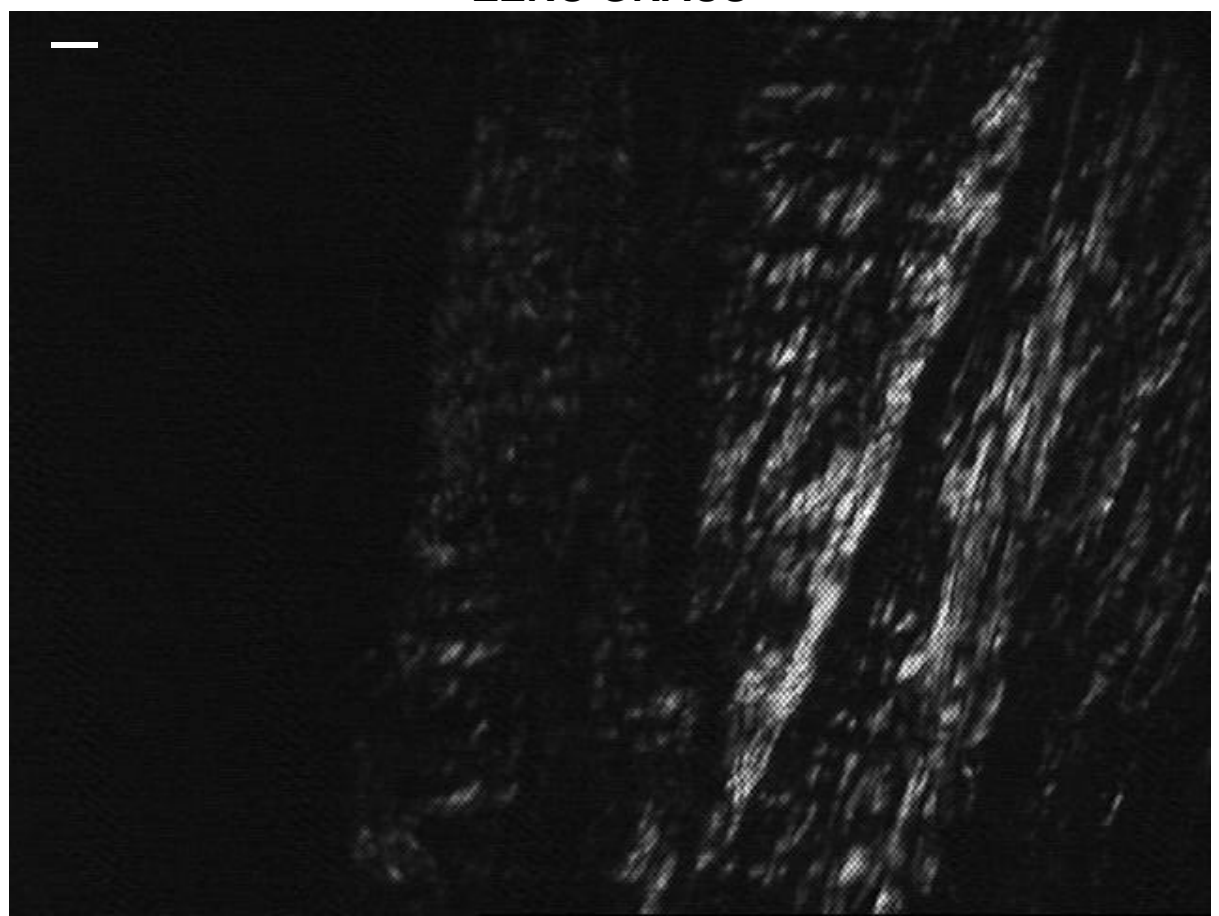

FIGURA 12 - Imagens referentes às observações qualitativas da análise de birrefringência total por meio de microscopia de luz polarizada dos tendões que sofreram lesão e tratamento placebo. A barra corresponde a $200 \mu \mathrm{m}$. 


\section{GRUPO III}

\section{$45^{\circ}$}

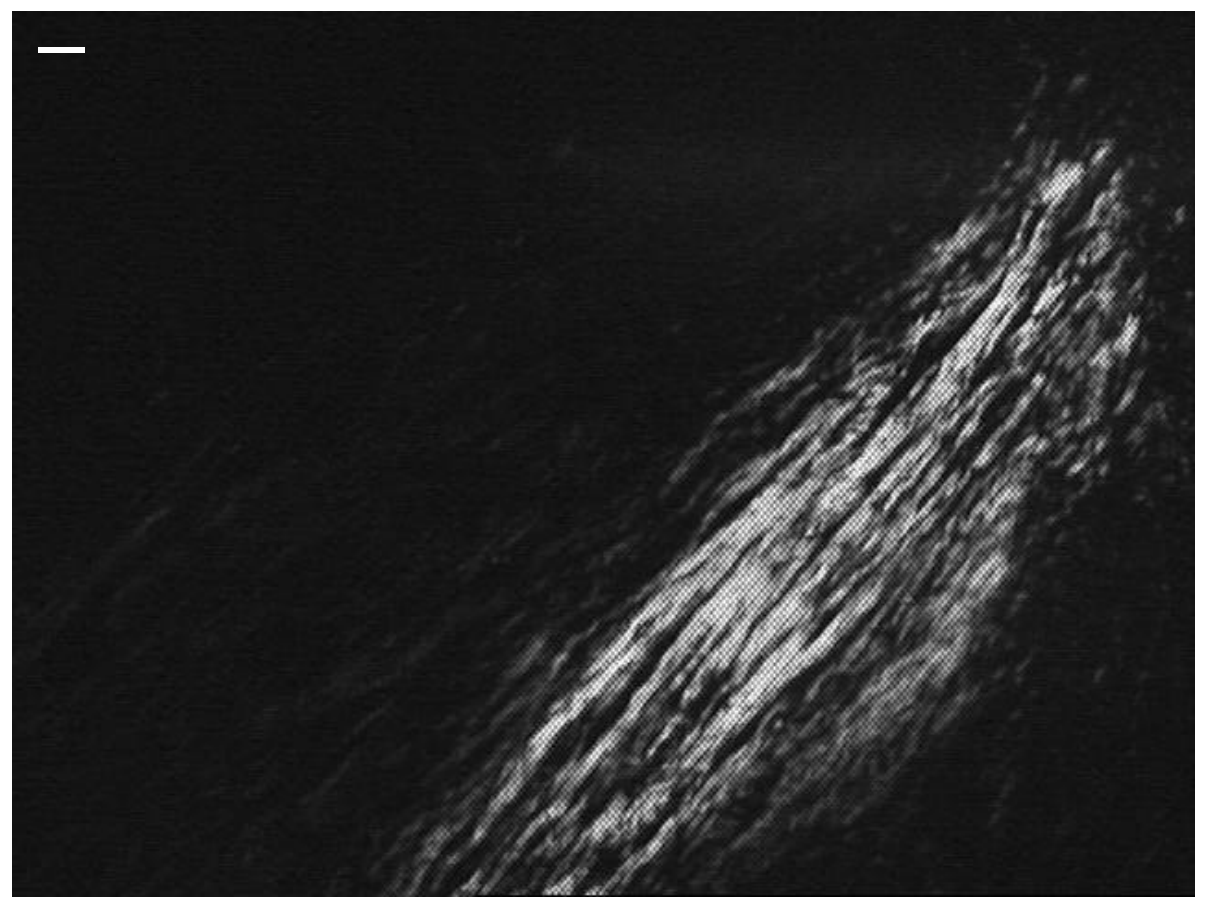

\section{ZERO GRAUS}

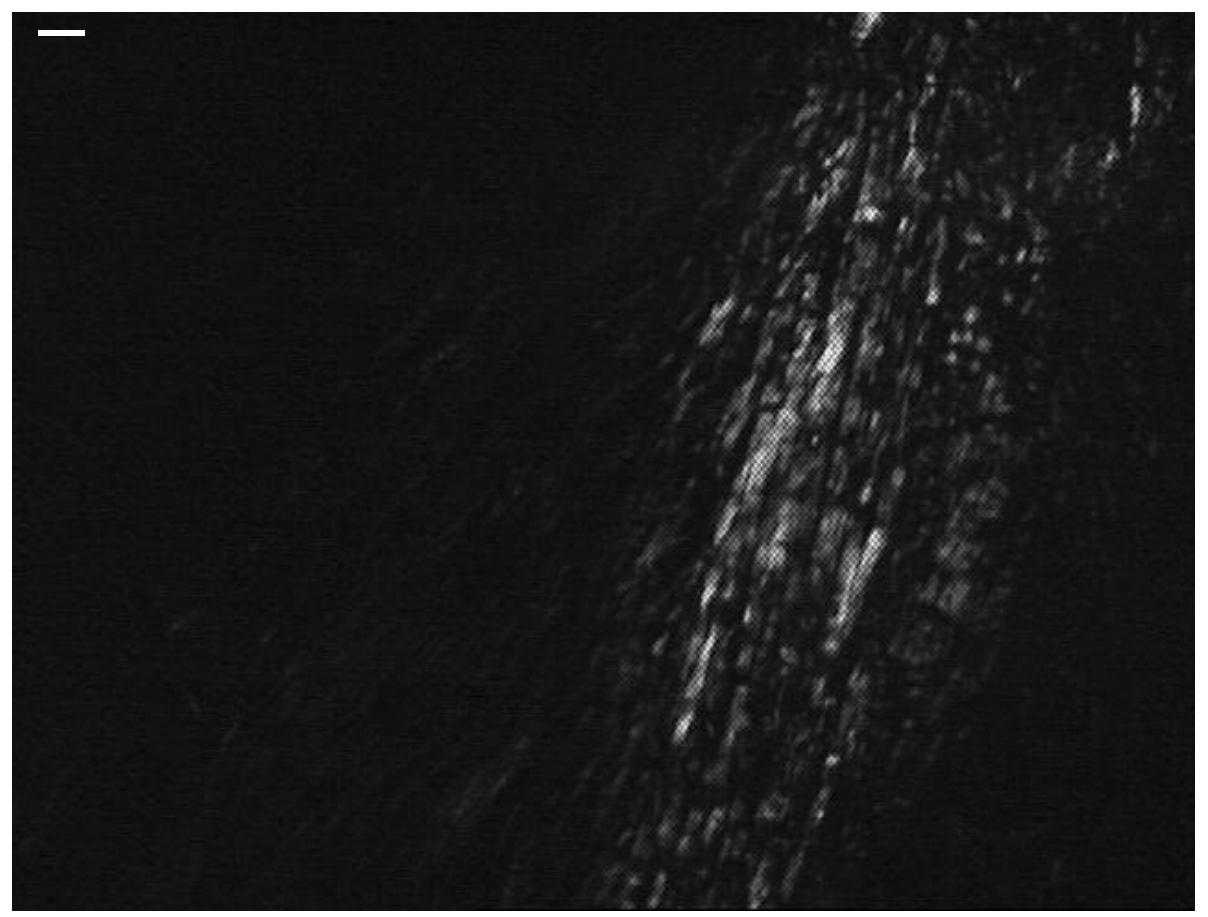

FIGURA 13 - Imagens referentes às observações qualitativas da análise de birrefringência total por meio de microscopia de luz polarizada dos tendões que sofreram lesão e tratamento com aplicação tópica de hidrocortisona. A barra corresponde a $200 \mu \mathrm{m}$. 


\section{GRUPO IV}

\section{$45^{\circ}$}

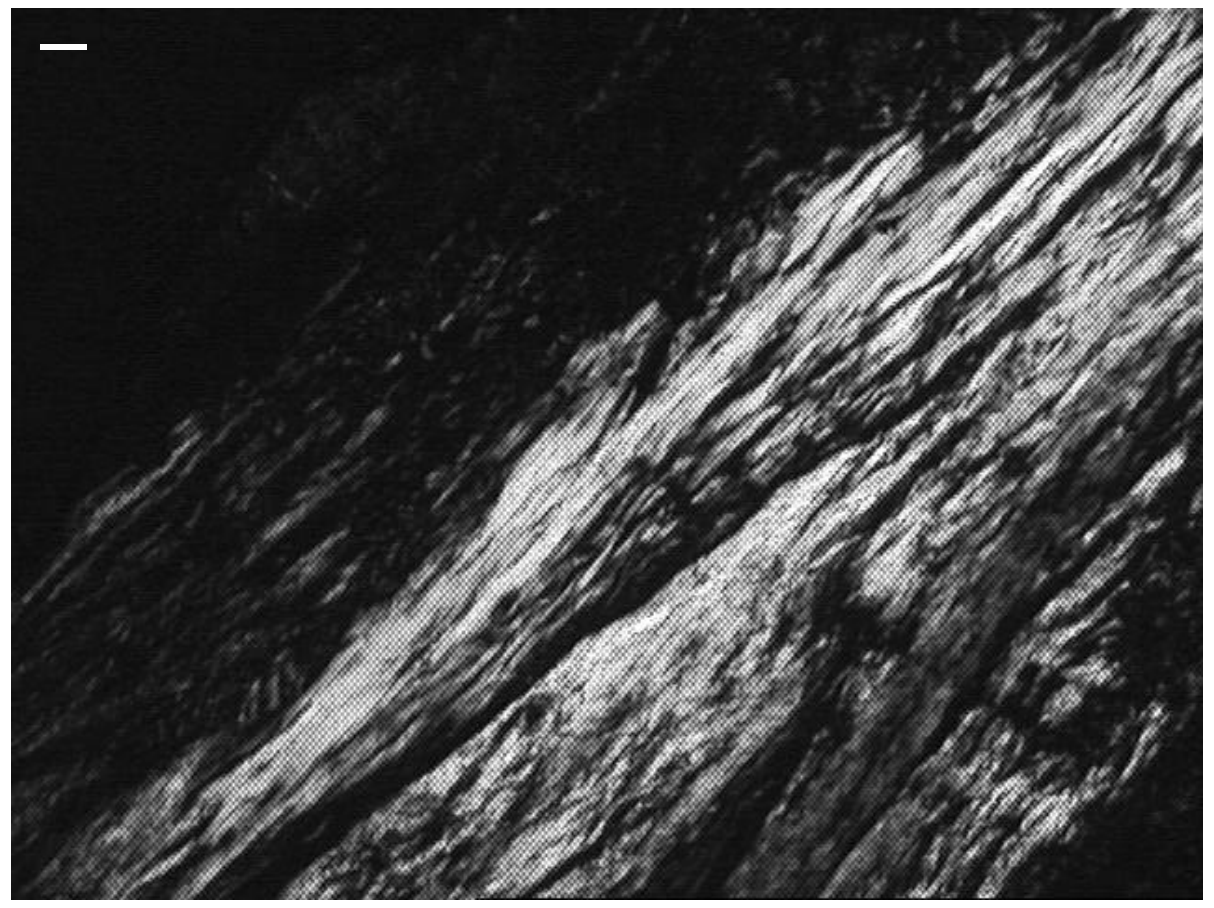

\section{ZERO GRAUS}

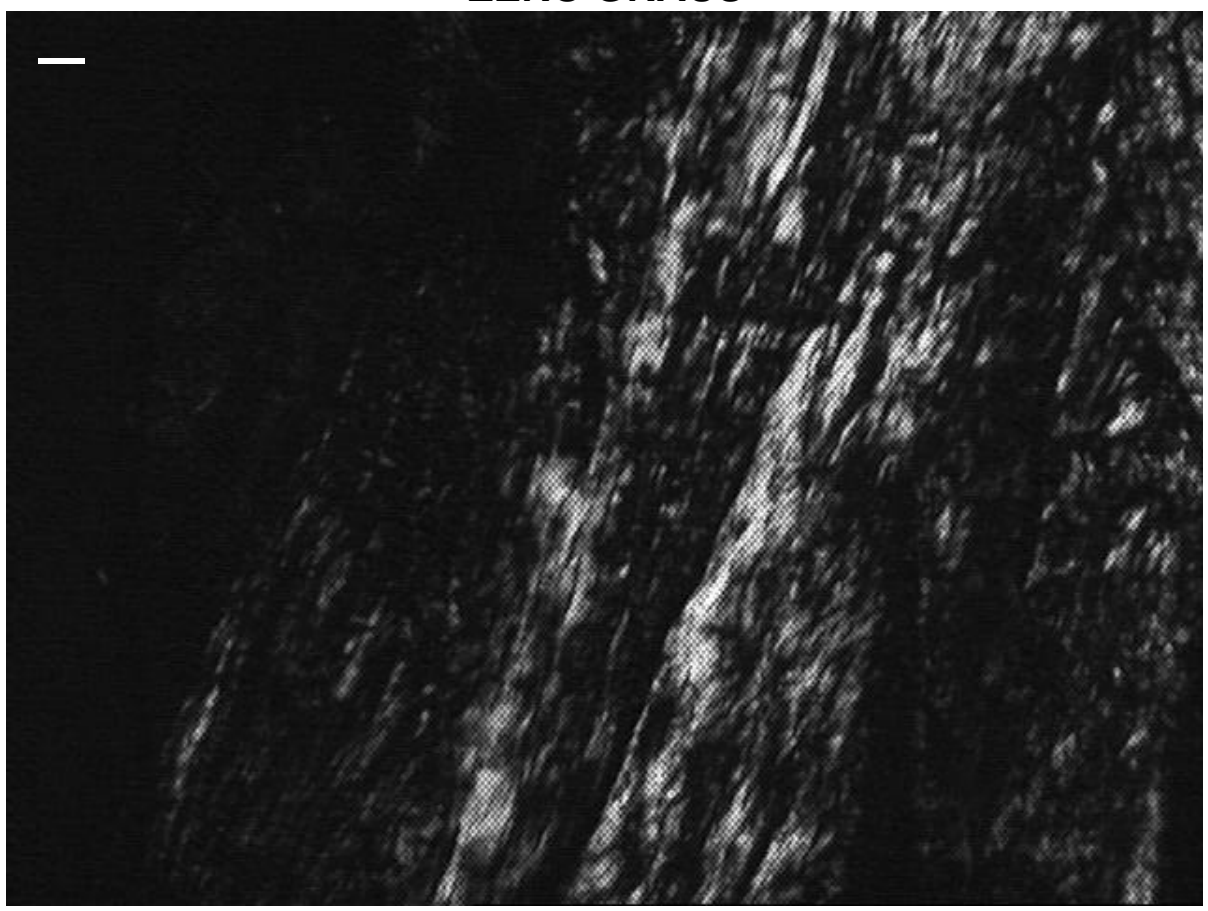

FIGURA 14 - Imagens referentes às observações qualitativas da análise de birrefringência total por meio de microscopia de luz polarizada dos tendões que sofreram lesão e tratamento com ultra-som terapêutico. A barra corresponde a $200 \mu \mathrm{m}$. 


\section{GRUPO V}

$45^{\circ}$

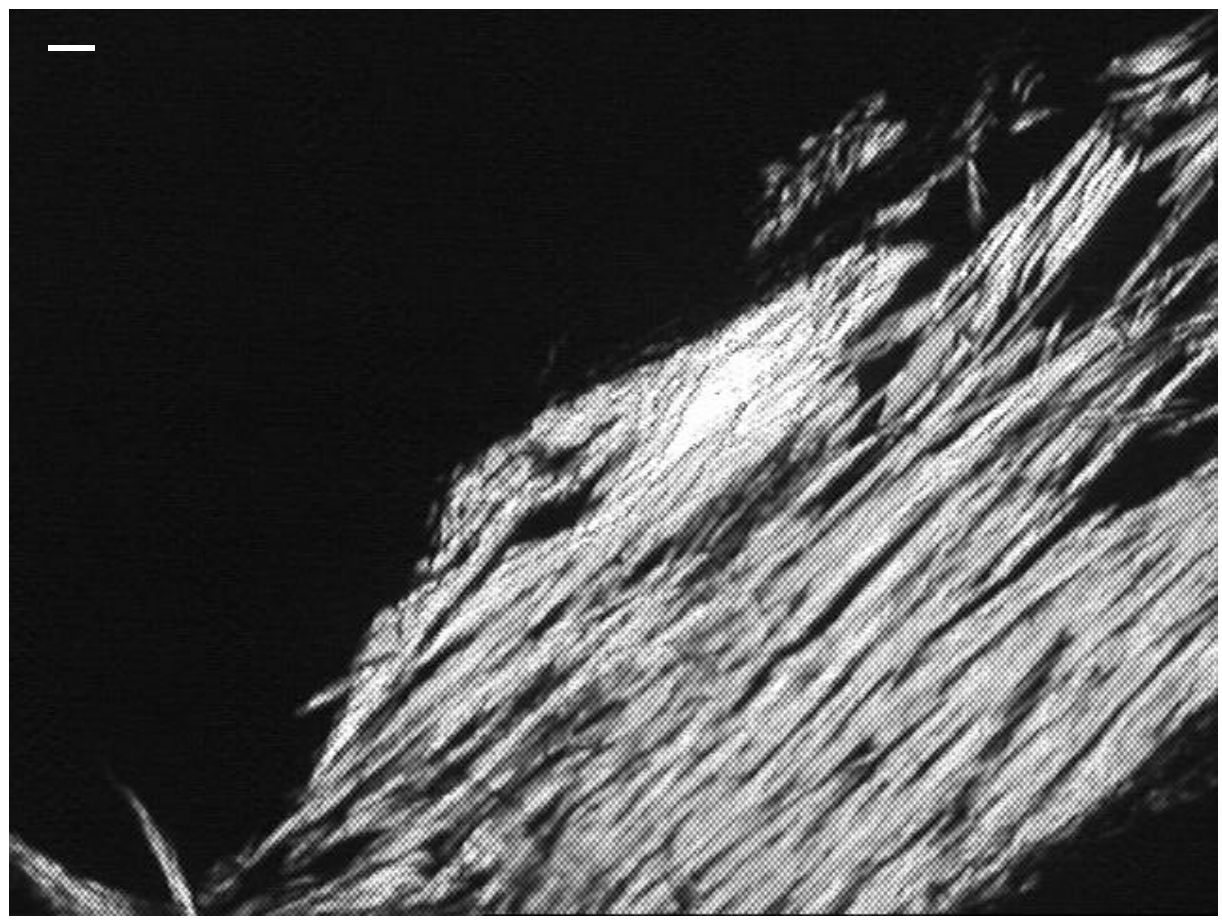

\section{ZERO GRAUS}

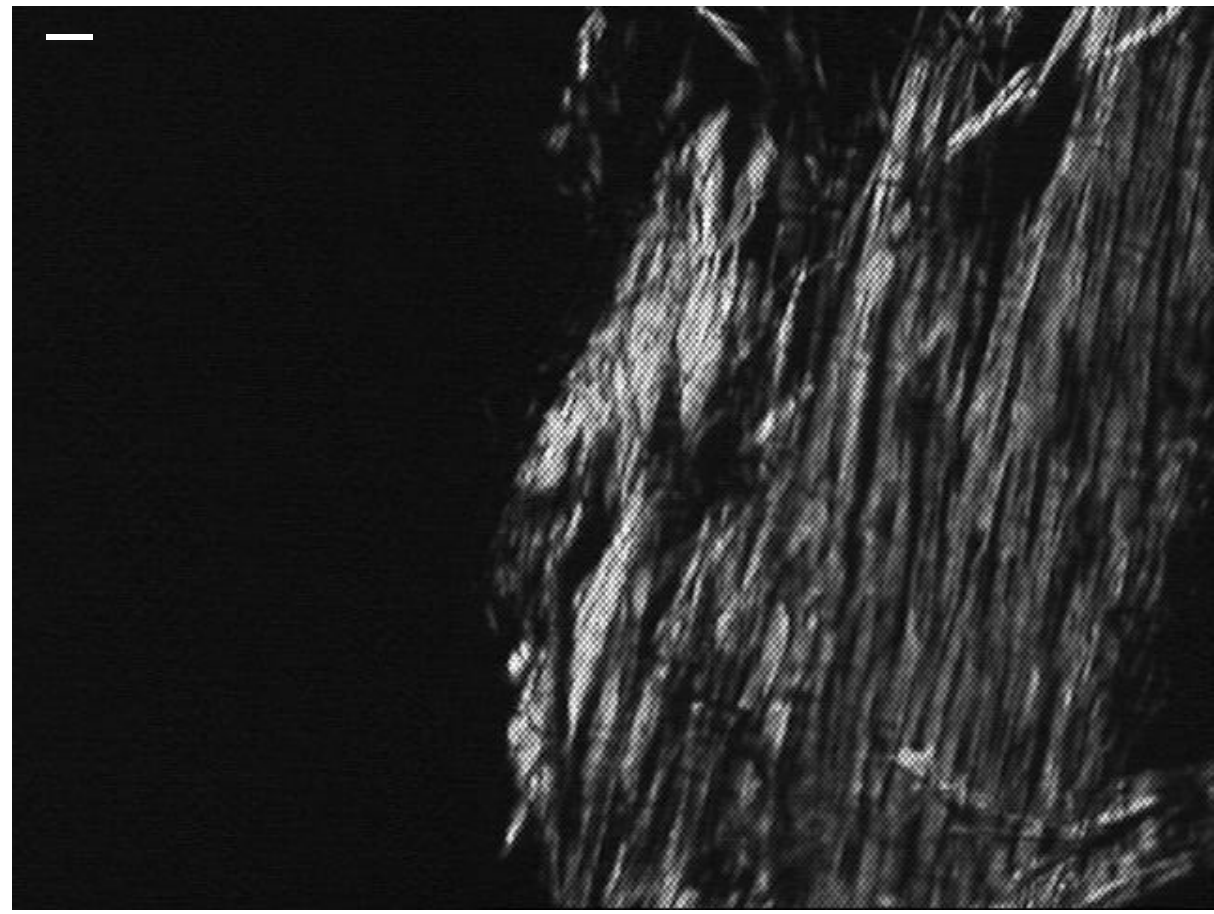

FIGURA 15 - Imagens referentes às observações qualitativas da análise de birrefringência total por meio de microscopia de luz polarizada dos tendões que sofreram lesão e tratamento com fonoforese. A barra corresponde a $200 \mu \mathrm{m}$. 


\section{IV.2 ANÁLISE QUANTITATIVA}

\section{IV.2.1 COMPARACÃO MÚLTIPLA DOS CINCO GRUPOS ESTUDADOS}

Para verificar se houve diferença estatisticamente significativa entre os grupos estudados, foi necessária a aplicação do teste de comparações múltiplas não paramétrico (em anexo C), apropriado ao teste de Kruskal-Wallis (CONOVER, 1980) forneceram os resultados da tabela a seguir:

TABELA 3 - Valores dos percentis observados $\left(t_{o b}\right)$ e os correspondentes $p$ valores para a comparação múltipla dos cinco grupos estudados.

\begin{tabular}{lcc}
\hline Grupos & $\mathbf{t}_{\text {ob }}$ & p valor \\
\hline $\mathbf{1} \times \mathbf{2}$ & 14.221131 & 0.0000 \\
$\mathbf{1} \times \mathbf{3}$ & 16.117282 & 0.0000 \\
$\mathbf{1} \times \mathbf{4}$ & 8.397239 & 0.0000 \\
$\mathbf{1} \times \mathbf{5}$ & 4.604938 & 0.0000 \\
$\mathbf{2} \times \mathbf{3}$ & 1.896151 & 0.0662 \\
$\mathbf{2} \times \mathbf{4}$ & 5.823892 & 0.0000 \\
$\mathbf{2} \times \mathbf{5}$ & 9.616193 & 0.0000 \\
$\mathbf{3} \mathbf{4}$ & 7.720043 & 0.0000 \\
$\mathbf{3} \mathbf{5}$ & 11.512344 & 0.0000 \\
$\mathbf{4} \mathbf{5}$ & 3.792302 & 0.0006 \\
\hline
\end{tabular}

Observa-se que o teste não rejeitou até a $6.62 \%$ de significância a hipótese de igualdade entre os Grupos II e III (o p valor foi 0.0662 ), em relação à medida observada (birrefringência).

Entretanto o teste rejeitou a igualdade entre os grupos a um nível de significância menor que $0.01 \%(p<0.0001)$ para a maioria das comparações. As 
exceções foram encontradas quando comparados os grupos II e III, citados acima, e quando comparamos os grupos IV e $\mathrm{V}$ onde se rejeita a igualdade entre os grupos para qualquer nível de significância acima de $0.06 \%$ $(p<0.0006)$.

Note-se que o nível de significância se refere à probabilidade de rejeitar a hipótese inicial dado que ela é verdadeira, portanto quanto menor o $p$ valor maior é a evidência de diferença entre os grupos (populações). Neste caso a hipótese inicial é que os grupos comparados dois a dois são iguais em relação às medidas de birrefringência.

Através dos testes conclui-se a um nível de significância de 5\% que somente os Grupos II e III são iguais, quanto à medida observada, elevando esse nível de significância a 10\% temos que todos os grupos são distintos.

Observando a análise descritiva dos dados percebe-se que os tratamentos aplicados aos Grupos II e III apresentaram, como resultado, os menores valores de birrefringência, sendo a mediana e média do Grupo II bem próximas, entretanto um pouco superiores, as observadas no Grupo III.

O tratamento que apresentou o melhor desempenho foi o aplicado ao Grupo V, produzindo maiores valores de birrefringência. Em segundo lugar ficou o tratamento aplicado ao Grupo IV. 


\section{DISCUSSÃO}

\section{V.1 DA METODOLOGIA}

O modelo ideal para avaliação das propriedades anisotrópicas ópticas a birrefringência de forma ou textural, em fibras de colágeno, seria em humanos, mas as exigências da sociedade moderna para os padrões apropriados de ética restringem rigorosamente o número de ocasiões em que estes testes possam ser efetuados. Como conseqüência modelos alternativos são necessários, levando assim à utilização de animais. Diferentes espécies animais são utilizadas, sendo que na literatura o mais encontrado é o rato. No presente trabalho utilizamos o rato, pois procuramos respeitar os níveis de pesquisa exigidos para a avaliação de tratamentos antes da sua indicação para seres humanos, já que a utilização da fonoforese no tratamento de tendão em processo de reparo é no momento pouco estudado.

$O$ rato é muito utilizado na avaliação da birrefringência nas fibras de colágeno do tendão (CUNHA, 2001; MELLO, 1975). A facilidade de sua obtenção em laboratório permite a eliminação de fatores individuais, como imuno deficiência de um animal, emprego de uma amostragem maior por grupo experimental, sempre que venha a interferir no resultado final do experimento, além de que, estes animais permitem a obtenção de resultados dentro de períodos de tempo mais curtos, devido ao seu metabolismo bastante acelerado em relação aos demais animais de experimento. Selecionou-se ratos machos devido as variações no ciclo hormonal das fêmeas. 
O tendão selecionado foi o calcanear, devido a facilidade de acesso, pois é um tecido superficial, e a forma anatômica mais ampla, o que reduz o trauma cirúrgico e permite facilidade na execução da técnica experimental.

Através da tenotomia induzida, muitos estudos experimentais sobre o processo de reparo tendíneo foram realizados (CUNHA et al., 2001, REDDY et al., 2001, ENWEMEKA \& REDDY, 2000; REDDY et al., 1998a, b; STEHNOBITTEL et al, 1998; GUN et al., 1997; ENWEMEKA, 1991a, b; ENWEMEKA et al., 1990; ENWEMEKA, 1989b; ENWEMEKA, 1988).

Muitos estudos têm utilizado o modelo de tenotomia para investigar a influência de agentes físicos sobre o reparo tendíneo.

O modelo experimental é essencial para adquirir resultados reprodutíveis. Portanto, foi utilizado no presente estudo, baseado em literatura, o modelo experimental de tenotomia induzida em tendões calcaneares de ratos, para investigar comparativamente o efeito da fonoforese, do ultra-som terapêutico e da aplicação tópica de hidrocortisona no processo de reparação tendínea.

De acordo com os resultados obtidos nos estudos de CUNHA, 2001; REDDY et al. 2001; ENWEMEKA \& REDDY, 2000; REDDY et al. 1998a, b; STEHNO-BITTEL et al, 1998; GUN et al. 1997; ENWEMEKA, 1991a, b; ENWEMEKA et al. 1990; ENWEMEKA, 1989b; ENWEMEKA, 1988, os quais demonstraram a ação de agentes terapêuticos sobre o processo de reparação tecidual em tendões calcaneares tenotomizados, tomou-se o cuidado de padronizar as variáveis do nosso modelo experimental.

Como anestesia, utilizou-se associação dos anestésicos Francotar® e Virbaxyl® $2 \%$, via intra muscular. Veterinários, indicam essa associação devido 
a seus excelentes resultados (OLIVEIRA, 2000), comprovados em nossa pesquisa. Sua grande eficiência deve-se a associação de um anestésico (Francotar ${ }^{\circledR}$ ) com um relaxante muscular e analgésico (Virbaxyl囚 2\%) que resulta em adequada sedação, prolongando o efeito anestésico, em animais com metabolismo intenso como os ratos, por um período aproximado de uma hora, tempo suficiente para todo procedimento operatório.

Como profilaxia antimicrobiana, de acordo œm o trabalho de DAVID et al. (1996), foi administrado intraperitonialmente em dose única CEFAZOLINA (20mg/100g de peso corporal).

Neste trabalho utilizamos o ultra-som terapêutico, tendo em vista o estudo de CUNHA et al. (2001), o qual foi o principal fator de motivação para a realização desta pesquisa.

CUNHA et al. (2001), teve como objetivo analisar a influência do tratamento do Ultra-Som Terapêutico (UST) em tendão de Aquiles de ratos, nas fases iniciais do processo de reparo tecidual. Foram utilizados 60 ratos machos da raça Wistar, pesando cerca de 200 gramas e 100 dias de vida, subdivididos aleatoriamente em 4 grupos de 15 animais cada. Dois grupos controle, sendo um grupo sem lesão (SL) e o outro com lesão e tratamento placebo (CL/PL), e dois grupos experimentais, os quais foram tratadas com UST, na freqüência de $1 \mathrm{MHz}$, intensidade de $0,5 \mathrm{~W} / \mathrm{cm} 2$ (médias temporais e espaciais), ERA de $0,5 \mathrm{~cm}$; por 300 segundos cada sessão e aplicação de forma direta com gel comum sobre a região do tendão. Os parâmetros foram diferenciados apenas em relação a modalidade de tratamento [contínuo (CL/USc) ou pulsado com regime de pulsação de 20\% (CL/USp)]. O tratamento constou de 10 sessões, iniciadas no primeiro dia de PO, durante 12 dias, ou 
seja, houve um intervalo de 2 dias após 5 sessões consecutivas, e a seguir mais 5 sessões consecutivas foram realizadas, simulando uma aplicação clínica. Os 60 animais foram sacrificados após 15 dias de pós operatório e seus tendões retirados cirurgicamente, processados para histologia e analisados qualitativa e quantitativamente, por meio da microscopia de luz polarizada afim de se obter dados sobre o estado de concentração, agregação e orientação das fibras de colágeno, utilizando para isso, medidas de birrefringência de total. A análise estatística foi realizada utilizando o Teste de Variância ANOVA para compararmos todos os grupos entre si, levando em consideração as suas variâncias. Os resultados demonstraram por meio de diferenças de valores de OR (nm), correspondentes à birrefringência total, que as moléculas de colágeno, responderam a estimulação ultra-sônica durante as fases iniciais do processo de reparo tecidual do tendão. O tratamento com UST no grupo de animais CL/PUL demonstrou ser um método físico eficiente, nas fases iniciais do processo de reparo, para a melhora da organização estrutural macromolecular, orientação e estado de agregação das fibras colágenas, uma vez que apresentou um valor de OR considerado estatisticamente maior que o OR do grupo CL/PL, acelerando o processo de reparo no local da lesão. Já o grupo CL/USc apresentou valores de OR estatisticamente mais baixos que o grupo CL/PL, indicando um desfavorecimento da estruturação normal que se desenvolve no sítio de lesão. Concluiu que nas condições que foi desenvolvido, houve diferenças na resposta organizacional do tecido tendinoso, relacionada com a modalidade da onda ultra-sônica aplicada; pois houve aceleração do processo de reparo tecidual quando foi realizado tratamento com UST na 
modalidade pulsada e uma piora ro processo de reparo tecidual quando foi realizado tratamento com UST na modalidade contínua.

Portanto, de acordo com o trabalho citado acima, somente o ultra-som na modalidade pulsada é capaz de gerar efeito terapêutico, pois o UST na modalidade contínua parece provocar uma pressão acústica forte o bastante, capaz de causar uma pressão local e prejudicar a formação de fibras colágenas na região da lesão tecidual.

Embora não haja um padrão de potência e técnica de emprego, o ultrasom terapêutico pode ser usado isoladamente ou como coadjuvante de outros tratamentos, sempre que se necessite de um efeito antiálgico (alívio de dor), efeito bioestimulante do trofismo celular (reparação celular) e efeito antiflamatório, antiedematoso e normalizador circulatório (reduação de edema e de hiperemia).

Tanto o UST como os antiflamatórios hormonais e não-hormonais são recursos amplamente utilizados em fisioterapia, de forma separada ou conjunta, para o tratamento em especial de patologias reumáticas, músculoesqueléticas e lesões de tecidos moles.

Nas inflamações é freqüente utilizar para o tratamento os corticosteróides. A hidrocortisona é um tipo de corticosteróide muito comum, disponível em várias formas como oral, tópico e parenteral. Os antiinflamatórios hormonais diminuem a inflamação através da supressão da migração dos leucócitos polimorfonucleares e revogação do aumento do fluxo sanguíneo capilar na área lesada (GILMAN et al., 1996). Além do que essas ações esteroidais suprimem a resposta imune normal. 
A hidrocortisona tem demonstrado ser um eficiente tratamento para as inflamações musculoesqueléticas. Nas inflamações agudas é comum utilizar a injeção aplicando diretamente no local da injúria. Corticosteróide oral pode também ser administrado para tratar inflamações.

Em razão dos efeitos colaterais indesejáveis (ex: gastrite medicamentosa), causados pela utilização de antiinflamatórios de via sistêmica (oral ou parenteral), incorrer constantemente, a indústria farmacêutica desenvolveu formulações tópicas dos antiinflamatórios, na forma de cremes ou géis. No entanto, as formulações tópicas dos antiinflamatórios não apresentam os mesmos resultados que por via sistêmica, pois a penetração através da pele não é muito eficiente.

Segundo MÜLLER et al. (1997), a via transcutânea para administração de antiinflamatórios dispõe de algumas vantagens em relação à administração oral, pois grande parte da dose administrada via sistêmica é rapidamente recolhido do metabolismo de primeira passagem e gera efeitos colaterais, como reações gastrintestinais, com formação até de ulcerações gástrica e duodenal e conseqüentes hemorragias. $O$ antiinflamatório tópico permite uma ação no local da inflamação. Além disso, a probabilidade de uma dose incorreta é reduzida e fica mais fácil interromper o tratamento desta maneira, através da remoção droga que está sobre a pele. Evita também os riscos e a inconveniência da terapia intravenosa. Nas artrites são usadas freqüentemente injeções, o que causa dor nos pacientes, este método é completamente invasivo e pode causar danos ao tecido.

Na fisioterapia a aplicação concomitante do UST e de antiinflamatórios tópicos na forma de gel já é uma maneira ordinária de agir em determinadas 
situações clínicas, sob a justificativa de que o UST favorece a penetração transcutânea do antiinflamatório tópico. Esta prática terapêutica ficou conhecida como fonoforese ou sonoforese.

Com o intuito de analisar a relevância e a confiabilidade do tratamento com fonoforese em desordens musculoesquléticas, PARIZOTTO et al. (2003) em sua meta-análise discutiu, entre uma seleta de 55 artigos publicados nos anos de 1954 a 2001, a importância e a presença de certos conceitos no processo de elaboração das pesquisas, os quais os autores acreditam ser essenciais na metodologia das pesquisas que se utilizam deste tipo de terapia. Logo, nosso trabalho respeitou os critérios metodológicos de PARIZOTTO et al. (2003), os quais podem se percebidos no capítulo MATERIAIS E MÉTODODS deste trabalho e os discutiremos a seguir:

- Grupo Controle

Segundo HASHISH (1986), a presença do grupo controle é fundamental, porque acredita na existência de efeito placebo.

DYSON (1987), defende que existem boas evidências de que um método de tratamento pode, às vezes, ter efeito placebo.

O efeito placebo tem sido observado em pacientes que receberam tratamento de ultra-som simulado. Isto sugere que este efeito pode ser mediado através de processos fisiológicos (HASHISH et al., 1988).

Nos estudos como os de WING (1982) e HOLDSWORTH \& ANDERSON (1993) não utilizaram o grupo controle. 
- Estudo Aleatório

É necessário que os estudos sejam de caráter aleatório devido à variação de respostas ao tratamento. Neste sentido, autores como GAM \& JOHANNSEN (1995), van der WINDT et al. (1999), HOLDSWORTH \& ADERSON (1993) e KLAIMAN et al. (1998) fizeram estudos aleatórios. BAKER et al. (2001) relata em seu trabalho que o estudo sendo aleatório proporciona evidências na evolução do conhecimento sobre os efeitos biofísicos do ultrasom, entre outras modalidades terapêuticas.

- Fármaco tipo antiinflamatório: hormonal e não-hormonal

É fundamental citar o tipo de fármaco utilizado.

Dentro dos antiinflamatórios utilizados em fonoforese, os hormonais freqüentemente são os mais usados, com destaque à hidrocortisona.

CAMERON \& MONROE (1992), hipotetizam, conforme os achados do seu trabalho, que a hidrocortisona na forma gel bloquearia as ondas sonoras. No entanto, BRASILEIRO et al. (2003) analisou a transmissibilidade ultrasônica de medicamentos utilizados na prática da fonoforese, como resultado nenhum medicamento na forma gel apresentaram condutibilidade negativa, apenas 1 um medicamento em gel apresentou uma transmissibilidade pobre e os 8 medicamentos restantes na forma gel, foram os que permitiram a melhor transmissibilidade nesta pesquisa. O trabalho de BRASULEIRO et al. (2003) segue a mesma metodologia proposta por CAMERON \& MONROE (1992).

A hipótese de CAMERON \& MONROE (1992) pode ser verdadeira caso as diferentes preparações farmacológicas tópicas causem uma variação nos coeficientes de transmissibilidade. 
- Fármaco manipulado na forma gel

Visto que o ultra-som é rapidamente atenuado no ar, e somente $0,1 \%$ da energia incidente é transmitida através da interface ar/tecido. Por isso, o ultrasom é sempre aplicado via um agente de acoplamento (TER HAAR, 1978).

A transmissão de energia do ultra-som através de um material para outro é dependente das propriedades físicas desse material, deixando claro a importância de estar escolhendo o meio de transmissão mais adequado.

Foi examinado um certo número de produtos, onde mensuraram algumas de suas propriedades físicas e avaliaram sua performance qualitativa. O gel foi considerado um excelente acoplador (CASAROTTO, 2000; DOCKER et al., 1982; REID \& CUMNINGS, 1977).

Atualmente o gel é o agente de acoplamento dominante na maioria dos estudos pesquisados, entretanto, foram encontradas formas muito variáveis destes agentes acopladores em nossa gama de referências utilizadas, como é o caso do creme (CICCONE et al., 1991; HOLDSWORTH \& ANDERSON, 1993) e da pomada (KLEINKORT \& WOOD, 1975; GRIFFIN et al., 1967).

- Valor de concentração do fármaco no gel

É de fundamental importância que os autores citem o valor das concentrações utilizadas para que estas possam servir de base para outros trabalhos, assim como foi para os estudos de KLEINKORT \& WOOD (1975), que comparou as diferentes concentrações de $1 \%$ e $10 \%$ de hidrocortisona e de BARE et al. (1996), onde usou a fonoforese de hidrocortisona à 10\%. Devido à grande gama dos valores de concentração administrados desta forma, é ainda empírica a utilização destes. CICCONE \& WOLF (1990), 
sugerem determinadas concentrações para diferentes tipos de fármacos antiinflamatórios hormonais ou não hormonais, baseado em observações clínicas e reportagens da literatura.

- Calibração do equipamento de ultra-som

FAY et al (1994), McCABE \& PYE (1997) e ZEQIRI (1997) relatam a importância da calibração dos aparelhos de ultra-som terapêutico, pois quando a potência de saída do transdutor não se iguala ao "display" destes equipamentos, há um comprometimento da segurança do paciente em relação ao tratamento.

Vários trabalhos já demonstraram que a maior parte dos equipamentos de ultra-som apresenta decréscimo de intensidade (STEWART et al., 1974; ALLEN \& BATTYE, 1978, FYFE \& PARNELL, 1982; GUIRRO \& SANTOS, 1997). Segundo GUIRRO \& SANTOS (1997) 50\% dos equipamentos de ultrasom, em uso rotineiro nas clínicas e departamentos de fisioterapia, estão fora das especificações postuladas pela International Eletrotechinical Commission (IEC), daí a importância de verificar se a potência de saída do transdutor se iguala ao display desse equipamento.

Portanto, a calibração dos equipamentos de ultra-som é ainda pertinente quanto à realidade reportada por diversos autores (STEWART et al., 1974; ALENN \& BATTYE, 1978; FYFE \& PARNELL, 1982; GUIRRO \& SANTOS, 1997). Contudo os autores como CICCONE et al. (1991); GRIFFIN et al. (1967); WING (1982); KLEINKORT \& WOOD (1975) não informaram em seus estudos sobre a calibração do ultra-som utilizado. 
- Número de sessões

Tratamentos fisioterapêuticos de dez sessões são considerados suficientes para a maioria dos planos de saúde. Seguindo esta proposta, os estudos mais recentes visam transpor a rotina clínica, além do que, dez sessões podem ser crucial a um tratamento inicial inflamatório do sistema musculoesquelético, atuando durante a fase inflamatória e a fase de proliferação que são decisivas para o reparo do tecido conjuntivo. No estudo de WING (1982), um protocolo de número de sessões idêntico ao proposto para nosso estudo foi encontrado.

ALVES (1988) obteve resultados benéficos no tratamento de queimaduras de terceiro grau de ratos, utilizando dias diferentes para 0 sacrifício dos animais. Os resultados foram mais satisfatórios no décimo dia de tratamento.

- Modo de emissão das ondas acústicas do equipamento (contínuo ou pulsado)

O modo de emissão das ondas ultra-sônicas pode ser decisiva para a deposição da droga pretendida. No modo contínuo, a geração da onda ultrasônica permanece constante durante todo o tempo, já no modo pulsado ela tem intervalos que devem ser citadas, porque podem ser variáveis. Porém, é muito mais freqüente na rotina clínica, o equipamento de ultra-som numa freqüência fixa de repetições de pulsos de $100 \mathrm{~Hz}$, os quais permitem que o efeito mecânico da terapia prevaleça sobre o efeito térmico.

McELNAY et al. (1993) relatou que o aumento da penetração da droga na pele pelo ultra-som é influenciado pelo modo de onda, contínua ou pulsada. 
FANG et al. (1999) demonstrou em seu experimento que o ultra-som pulsado com ciclo de trabalho reduzido é mais efetivo na acentuação da permeabilidade do clobetasol 17-propionato do que o modo contínuo. Isto contradiz os relatos descritos por CICCONE et al. (1991). Até o presente momento, não há uma conclusão final sobre o aspecto do uso do ultra-som na modalidade contínua ou pulsada, em relação a efetividade na introdução de drogas por fonoforese.

\section{- Freqüência do transdutor (citado)}

Existe um aumento quase linear nos coeficientes de absorção e atenuação dos tecidos, com o aumento da freqüência da onda, ou seja, quanto maior a freqüência, mais eficaz será a absorção da energia. Ao optar por um transdutor, deve-se conhecer estes conceitos porque é possível proporcionar uma deposição de drogas específicas. Observa-se também, que os valores dos coeficientes de absorção e atenuação são variáveis de tecido para tecido.

Uma variedade de freqüências de transdutores tem sido encontradas dentro da literatura, muito alta freqüência $15 \mathrm{MHz}$ (BYL et al., 1993), alta freqüência 1-3 MHz (MITRAGOTRi et al., 1995a), baixa freqüência $150 \mathrm{kHz}$ (UEDA et al., 1996) e muito baixa freqüência $20 \mathrm{kHz}$ (MITRAGOTRI et al., 1996).

As freqüências do transdutor do aparelho de ultra-som têm observações atualizadas referindo-se à determinação deste parâmetro em relação à passagem de drogas. MEIDAN et al. (1999) observou em seu estudo que no geral o efeito de sonificação do transdutor de 1.1 MHz e $3.3 \mathrm{MHz}$ é o mesmo. Porém, observou-se que há uma maior tendência do uso dos transdutores com freqüências próximas de $1.1 \mathrm{MHz}$, devido ao conceito que já esta bem 
estabelecida na literatura que, quanto maior a freqüência da onda ultra-sônica, menor será sua penetração nos tecidos. Porém, DEMMINK et al. (2003) em seus achados verificou que não há freqüência-dependência sobre a profundidade de penetração do calor quando a intenção é o efeito térmico.

- Intensidade

A deposição de drogas aplicadas topicamente pode ser acentuada por uma variedade de parâmetros, incluindo intensidade. Alguns fenômenos induzidos pelo ultra-som em tecido biológico são conhecidos por requerer um limiar de dose (FRIZZEL et al., 1977; BASURI \& LELE, 1962). Se o limiar de dose existe, ele ainda não é conhecido. No trabalho de MITRAGOTRI et al. (2000) os achados foram dependentes do limiar da dose de energia do ultrasom.

No estudo de WARDEN \& MCMEEKEN (2002), foi verificado que os fisioterapeutas entrevistados utilizam predominantemente o UST no modo pulsado em uma intensidade de $0,5 \mathrm{w} / \mathrm{cm}^{2}$.

No modo pulsado, é muito importante que a intensidade acústica temporal e espacial (SATA) seja citada nos trabalhos, pois se você deseja introduzir uma determinada quantidade de energia acústica no paciente, isto é, a mesma intensidade média temporal, então a intensidade dentro de cada pulso tem de ser progressivamente aumentada na medida em que você aumenta a distância entre os pulsos.

Um problema que dificulta conclusões sobre a efetividade das dosagens é a grande diversidade de problemas tratados pelo ultra-som e os diferentes momentos clínicos nos quais são aplicados. 
O movimento do transdutor é um dado importante para observar como a energia irradiada se distribuirá no tecido alvo. Para assegurarmos um tratamento mais seguro e uniforme possível da área, procuramos manter a cabeça de tratamento em pequenos movimentos lentos, circulares, contínuos e uniformes, conhecido como método dinâmico (HOOGLAND, 1986). O transdutor deve ser manipulado a uma velocidade aproximada de $1 \mathrm{~cm} . \mathrm{s}^{-1}$ (BYL et al., 1993). Outros autores utilizam o transdutor na forma estacionária durante a fonoforese. Considerando a característica de interação biofísica do ultra-som com os tecidos, esta modalidade estacionária deveria ser evitada.

\section{- Tempo e ERA}

O tempo real de tratamento é determinado pelo tamanho da área a ser tratada. Então, quando a ERA do transdutor do ultra-som é citada, é possível determinar a duração do tratamento. OAKLEY (1978) dá como regra geral, 1 a 2 minutos para cada área de uma vez e meia o tamanho do transdutor.

No estudo de GRIFFIN et al (1967) foi apresentado um protocolo que determinava a duração do tratamento, pelo tamanho da área tratada usando 5 minutos para cada 25 polegadas quadradas $\left(63,5 \mathrm{~cm}^{2}\right)$ de pele, sendo necessário conhecer a ERA do transdutor, como foi proposto por OAKLEY (1978).

Atualmente, devido às investigações laboratorial, a fonoforese está deixando de ser uma forma de tratamento totalmente empírica, pois até pouco tempo atrás ainda não havia comprovação. As evidências surgiram após algumas investigações, tal como as de CAGNIE et al., (2003); SMITH et al. 
(2003); ASANO et al., (1997); MITRAGOTRI et al., (1995a, b); BYL et al., (1993); McELNAY et al., (1993).

Após os períodos experimentais, os animais foram sacrificados (inalação excessiva de éter sulfúrico), as peças removidas e houve a realização da tramitação laboratorial. Posteriormente a confecção dos blocos, seguiu os procedimentos adequados (citados no capítulo MATERIAIS E MÉTODOS) para a análise da birrefringência das fibras de colágeno.

Segundo CONNER-KERR et al. (1998), o exame do tecido localizado sob o local da aplicação da droga tópica revela a indução do efeito local.

VIDAL (2003), relata que a melhor maneira para se detectar e descrever a orientação das fibras de colágeno é através das propriedades físicas tal como a birrefringência, inicialmente proposta por VIDAL (1964).

Para revelar a birrefringência da fibra de colágeno usa-se a microscopia de luz polarizada (VIDAL, 2003).

Portanto, a utilização da microscopia de luz polarizada revela a birrefringência da fibra de colágeno e permite de modo acurado medir, interpretar e validar a alta organização.

\section{V.2 DOS RESULTADOS}

Os nossos resultados sugerem que após a lesão do tendão há uma variação da birrefringência das fibras de colágeno quando comparada ao grupo I, a síntese das fibras de colágeno são orientadas em relação ao eixo longo, e que através dos tratamentos dos grupos IV e $\mathrm{V}$ houve um aumento dos valores de OR. No entanto, MELLO \& VIDAL (2003) verificaram que as novas fibras de 
colágeno do tendão, sintetizadas após uma lesão, não possuem um arranjo perfeito como de um tendão não lesado, o que pode comprometer na atividade funcional das fibras de colágeno.

Os valores de OR são significantemente maior para o grupo controle padrão (GI), quando comparado com valores de OR dos demais grupos tenotomizados. Isto pode ser explicado pelo alto grau de empacotamento e organização das fibras de colágeno nos tendões deste grupo, uma vez que não sofreram nenhum tipo de lesão. Esses dados estão condizentes com o trabalho de VIDAL \& CARVALHO (1990), tanto em relação a idade do animal como a espessura do corte do tendão na lâmina, demonstrando uma acuracidade das medidas.

Os animais do grupo Gll apresentaram valores de OR estatisticamente menores que os valores de OR encontrados no grupo GI, o que já era esperado, pois o grupo Gll representa uma cicatrização sem intervenção de um mecanismo externo. Esses resultados indicam uma organização insipiente das fibras de colágeno na região central, local da lesão.

O grupo de animais que foram lesados e tratados com a aplicação tópica de hidrocortisona (GIII), teve os seus valores de OR estatisticamente igual aos do GIl, portanto, este tipo de tratamento não demonstrou efeito estimulante em relação à aceleração do processo de reparo tendinoso, representando a não penetração da hidrocortisona no local da lesão.

Tanto os resultados do Gll como os do GIll demonstraram que os seus tendões tiveram uma organização e agregação das fibras colágenas de curso normal. Nestes dois grupos foi observado um eixo de orientação alinhado ao 
eixo do tendão primitivo, porém a maior parte deste material foi agregada de forma desorganizada.

VOGEL (1974), demonstra que a força do tendão é dependente da quantidade, tipo e orientação espacial de suas fibras. Propriedades como transmissão de tensão do tendão é refletida na estrutura compacta e alinhamento longitudinal de suas fibras.

Através dos grupos GIV e GV, vimos que a interação da onda ultrasônica com molécula de colágeno provoca uma reação estimulante favorável ao processo de reparo tecidual em estágios iniciais, o que é o que pode ser correlacionados com os trabalhos de YASUDA (1954); FUKADA \& YASUDA (1957); SILVA (1987); GUERINO et al. (1997) e CUNHA et al. (2001). Portanto, os grupos experimentais que usaram o UST na modalidade pulsada a $100 \mathrm{~Hz}$ e regime de pulsação de $20 \%$ (GIV e GV), obtiveram como resultado um efeito estimulante que aumentou a síntese de colágeno e a deposição de fibras no espaço da reparação. Entretanto, no estudo de WARDEN \& MCMEEKEN (2002), apenas 34\% dos fisioterapeutas entrevistados utilizam o UST para estimular a síntese de colágeno em estágios iniciais.

Ainda sobre os grupos GIV e GV, sucedeu-se uma superioridade de agregação e alinhamento das fibras de colágeno no eixo longo dos tendões, evidenciando maior brilho de birrefringência (representado quantitativamente pelo valor de OR) do que nos tendões dos grupos Gll e Glll.

A influência positiva do UST, sobre a organização e agregação das fibras colágenas em tendões em processo de reparo ocorre provavelmente devido às suas propriedades piezoelétricas, que provocam no tecido alvo compressões mecânicas e induzem trocas elétricas nas superfícies externas, 
criando potenciais elétricos de baixa amplitude (YASUDA, 1954; FUKADA \& YASUDA, 1957; BASSET \& BECKER,1962; MARINO \& BECKER, 1970; BASSET, 1982; SILVA, 1987; BYL et al., 1993; GUERINO et al., 1997).

Segundo VILARTA \& VIDAL (1989); VIDAL \& CARVALHO (1990) e ENWEMEKA \& SPIELHOLZ (1992), são de grande importância as microcorrentes geradas nas regiões moleculares, que parecem funcionar como uma sinalização para a síntese e organização das moléculas de colágeno, sua extrusão dos fibroblastos, especialmente no tendão, que depende desta ordem molecular para desenvolver bem suas funções mecânicas.

Nossos resultados vêm concordar com a influência da ação piezolétrica das ondas ultra-sônicas no tecido, propiciando organização da matriz extracelular, síntese de moléculas e agregação de fibras colágenas, quando reportamos aos efeitos encontrados no tratamento de tendões com UST na modalidade pulsada a $100 \mathrm{~Hz}$ e regime de pulsação de $20 \%$.

Porém, o melhor tratamento aconteceu no grupo GV, no qual os animais foram tratados com fonoforese. Indicando, que as ondas mecânicas não participaram isoladamente da superioridade deste grupo em relação à eficácia terapêutica, ou seja, a hipótese de que o UST facilitaria a penetração de um antiinflamatório gel, via transcutânea, parece ser verdadeira.

No entanto, os mecanismos de ação da fonoforese não estão totalmente esclarecidos.

Segundo TER HAAR (1987), o calor e a cavitação são os mecanismos que causam a maioria dos efeitos terapêuticos do ultra-som. 
Provavelmente, são também os dois mecanismos que explicam a facilitação da penetração transcutânea de medicamentos na pele tratada com esse recurso.

De acordo com BYL (1995), tanto os efeitos térmicos como os efeitos mecânicos têm sido considerados como capazes de facilitar a penetração de drogas aplicadas topicamente.

Algumas hipóteses sobre a relação do efeito térmico e mecânico com a fonoforese seriam:

- O aquecimento da pele através do ultra-som causaria um aumento de energia cinética nas moléculas da droga e na membrana celular, dilatação de folículos pilosos e glândulas sudoríparas, e aumento da circulação da área irradiada (BYL, 1995). Essas mudanças fisiológicas podem favorecer a difusão das moléculas da droga através da camada córnea e ser coletada pela rede de capilares na derme (BYL, 1995).

- Considerando que a baixa permeabilidade da pele é atribuída à estrutura altamente ordenada dos queratinócitos e suas camadas lipídicas, presentes na camada córnea (JUNQUEIRA \& CARNEIRO, 1999). O efeito mecânico (a cavitação) do ultra-som provocaria uma mudança no arranjo da camada córnea da pele (WU et al., 1998).

Segundo BYL et al., (1993), McELNAY et al., (1993), MITRAGOTRI et al., (1995b), WEIMANN \& WU (2002) e SMITH et al. (2003), a principal 
hipótese é a de que seja o efeito de cavitação, provocado pelo ultra-som, a responsável pelo fenômeno da fonoforese.

HILL (1972), tendo em vista que o mecanismo térmico já estava bem fundado e que o mecanismo de cavitação não era bem entendida, resolveu investigar o fenômeno da cavitação. Para isso, o experimento foi realizado in vitro, onde observou que há uma dependência na freqüência e intensidade. $\mathrm{Na}$ freqüência de $1 \mathrm{MHz}$, a cavitação surgi com uma intensidade de aproximadamente $0,5 \mathrm{~W} / \mathrm{cm}^{2}$. Porém, para a formação da cavitação existe a dependência de outros parâmetros como duração de pulso, ciclo de trabalho, pressão do ambiente e a estrutura do meio irradiado.

HILL (1972), baseado nos achados do seu experimento in vitro, acredita que a atividade de cavitação seja difícil de ocorrer em tecidos de mamíferos.

No trabalho de BARNETT et al. (1994), a cavitação é vista como o responsável pela maior parte dos efeitos biológicos. Este trabalho relata a possibilidade de um UST pulsado na intensidade de $0,5 \mathrm{~W} / \mathrm{cm}^{2}$ promover efeitos benéficos em reparação de tecidos devido o mecanismo de cavitação. No entanto, os autores chamam a atenção, visto que a geração da cavitação não é bem controlada, sobre a necessidade de pesquisas para se determinar o controle deste mecanismo, o que é uma questão de segurança para a aplicação do ultra-som.

Tendo como referência os achados de CAGNIE et al. (2003), ROSIM \& BARBIERI (2003), ASANO et al. (1997), o mecanismo de cavitação parece ser plausível.

ASANO et al. (1997), sem interferir com a temperatura hipodérmica, favoreceu um aumento significativo da penetração de indometacina por meio 
de um UST pulsado de $1 \mathrm{MHz}$ de freqüência e intensidade de 0,5 W/cm${ }^{2}$, irradiando durante 10 minutos. Este experimento foi monitorado por meio de termistores.

Os resultados de ROSIM \& BARBIERI (2003) parecem corroborar com a hipótese da cavitação, pois houve facilitação significativa da absorção transcutânea do diclofenato sódico com a irradiação ultra-sônica prévia, usando intensidade de $0,5 \mathrm{~W} / \mathrm{cm}^{2}$ e tempo de aplicação de 5 minutos. Embora a temperatura hipodérmica não tenha sido monitorada, sabe-se que a energia sonora é convertida em energia térmica proporcionalmente à intensidade do ultra-som e na intensidade empregada os efeitos térmicos são quase que desprezíveis. Além disso, o gel diclofenato sódico foi aplicado após a cessação da irradiação com o ultra-som, o que leva a acreditar que eventuais aumentos da temperatura local possam ter sido rapidamente dissipados pelos mecanismos fisiológicos normais e que a facilitação da absorção tenha ocorrido por alteração da estrutura cutânea pela cavitação, o que de fato ocorre, como demonstrado por McELNAY et al. (1993).

A hipótese da cavitação torna-se mais evidente no estudo de CAGNIE et al. (2003), no qual 29 pacientes com desordens no joelho necessitariam de artroscopia. Os pacientes foram distribuídos aleatoriamente em 3 grupos. Os grupos denominados grupo A $(n=10)$ e B $(n=10)$ foram tratados com fonororese. O grupo $\mathrm{C}$ recebeu como tratamento à aplicação tópica do antiinflamatório, através da simulação do ultra-som durante 5 minutos. A utilização do ultra-som, no grupo A e B, foi de acordo com os autores a mais próxima da prática clínica fisioterápica. O grupo A recebeu tratamento com ultra-som contínuo (1 MHz, $1.5 \mathrm{~W} / \mathrm{cm}^{2}$, por 5 minutos). O grupo B recebeu 
tratmento com ultra-som pulsado $(100 \mathrm{~Hz}, 20 \%$ de ciclo de trabalho). Para todos os grupos foi utilizado o antiinflamatório ketoprofen gel. Por meio de cromatografia foi verificado a concentração do ketoprofem na biópsia do tecido biológico. Estatisticamente, somente as concentrações encontradas nos grupos tratados com fonoforese foram significante. Os autores concluem o estudo, elegendo o ultra-som pulsado o mais eficaz para fonoforese.

Por conseguinte, os estudos citados acima demonstraram que é mais provável que a cavitação seja o principal mecanismo da facilitação pelo ultrasom da penetração transcutânea dos antiinflamatórios. Além disso, CUNHA et al. (2001) observou que somente o ultra-som pulsado (efeito não térmico) é causador de efeitos terapêuticos no processo de reparo de tendão. Portanto, mesmo que o ultra-som contínuo (efeito térmico) também facilite a penetração de um medicamento tópico, não se pode considerar útil para utilização terapêutica da fonoforese, já que este parece provocar uma pressão acústica forte o bastante, capaz de causar uma pressão local e prejudicar a formação de fibras colágenas na região da lesão de tendão.

Segundo WEIMANN \& WU (2002), não é apenas a desordem estrutural na epiderme (cavitação) o mecanismo de ação do UST, mas também o emprego de uma "força" adicional (onda mecânica) ou pressão de radiação na difusão através da pele.

Por anos ficou estabelecido que toda aplicação de um medicamento tópico se difundia da epiderme para a derme e seguia a rede capilar, sendo sistêmico, e então retornavam para o alvo da aplicação pela circulação sanguínea (BYL, 1995). Mas sabe-se hoje que esta não é a única via, há também a via direta, pois uma grande quantidade do medicamento tópico não 
entra na rede capilar da epiderme e derme, seguindo a área imediatamente abaixo do local da aplicação, tal como o tendão (BYL, 1995).

Segundo RABINOWITZ (1988) existem duas maneiras distintas para a deposição de um medicamento, a local e a sistêmica. Logo, o tendão calcanear é um tipo de tecido que se aproveita das duas vias, pois se localiza superficialmente a pele e é vascularizada.

De acordo com MELLO et al. (1975), VIDAL (1987b) e MELLO \& VIDAL (2003), durante o processo de reparo de tendão as fibras de colágeno tornamse gradativamente mais espessas e seu brilho de birrefringência aumenta, indicando uma melhor organização e estado de agregação macromolecular. Os resultados que obtivemos neste trabalho demonstram claramente isso quando reportamos aos resultados dos animais do grupo Gll e GIII, que demonstram um baixo retardo óptico comparado com o grupo Gl, evidenciando que existe alteração da morfologia do colágeno após a lesão. Seguindo a mesma linha de raciocínio, os animais tratados do grupo GIV e GV modificaram as suas propriedades anisotrópicas. Portanto, concordando com as afirmações de VIDAL (2003) e VIDAL (1987a), neste trabalho, a microscopia de polarização mostrou ser um meio de análise valioso para o estudo da matriz extracelular, permitindo levantar informações a respeito da organização molecular da mesma, por isso mesmo podendo ser considerada um meio de pesquisa da infra-estrutura da matriz. Permitiu ainda, a detecção e quantificação do fenômeno anisotrópico do colágeno denominado birrefringência.

Para melhorar as observações morfológicas dos nossos resultados colocamos o principal eixo do tendão orientado em aproximadamente $45^{\circ}$ e $0^{\circ}$ dos polarizadores, onde foi possível analisar vários aspectos qualitativos da 
geometria helicoidal, da organização da superfície das fibras de colágeno e das ondulações na superfície do crimp, Em qualquer ângulo é possível observar o crimp (VIDAL, 2003), mas é em $0^{\circ}$ onde conseguimos a caracterização morfológica e helicoidal detalhada.

BARANAUSKAS et al. (1998), demonstrou mudanças na organização da superfície das fibras do tendão, através do microscópio de força atômica.

Talvez os efeitos benéficos dos grupos GIV e GV foram mais pronunciados neste estudo, uma vez que a liberdade para a marcha produz um estresse e tração funcionais no tecido tendíneo lesado, os quais são um estímulo físico significante na formação e manutenção do colágeno no tecido conjuntivo denso. O aumento de estresse funcional causa um acréscimo na produção e organização de colágeno, os quais são explicados pela piezoeletricidade própria do colágeno, que é desfavorecida com a imobilização de um membro lesado (ENWEMEKA et al., 1998; ENWEMEKA, 1992 e STEHNO-BITTEL et al., 1998).

VILARTA \& VIDAL (1989), demonstram a importância da piezoeletricidade na formação do tendão, fazendo uma comparação entre os animais submetidos ao exercício (produzindo tração e aumentando a atividade piezoelétrica no tecido) com a desnervação como um modelo para diminuir a piezoeletricidade. A análise dos tendões de ambos os grupos foi realizada com microscopia de luz polarizada. Como resultados, obtiveram ORs ( $\mathrm{nm}$ ) bastante aumentados nos animais que foram submetidos ao exercício físico em relação aos animais desnervados, concluindo que o exercício, ou seja a tração, aumenta a produção, o alinhamento e agregação das fibras colágenas no tendão, observados por meio da microscopia de luz polarizada. 
VIDAL (2003), discute sobre o conceito das propriedades piezoelétricas do colágeno do tendão, onde correlaciona a propriedade piezoelétrica do osso como sendo uma sinalização osteoblástica. Por isso, acredita-se que este conceito pode ser aplicado para as fibras de colágeno do tendão. Neste caso, o colágeno geraria um sinal para as células através da piezoeletricidade.

A proposição é que os feixes de colágeno atuem como transdutor de sinais para as células via piezoeletricidade (VIDAL, 2003).

Relatos contraditórios, em relação aos nossos, foram encontrados nos artigos de PARIZOTTO et al. (2003), ROBERTSON \& BAKER (2001), BAKER et al. (2001), van der WINDT et al. (1999).

ROBERTSON \& BAKER (2001), em uma revisão sistemática encontraram pouca evidência do ultra-som quando comparado ao grupo placebo no tratamento de pessoas com dor, lesões muculoesqueléticas ou para promover a cicatrização de tecidos moles.

BAKER et al., (2001), contestaram a efetividade dos efeitos biofísicos do ultra-som.

Em outra revisão sistemática van der WINDT et al. (1999) não mencionam evidência clínica ou estatisticamente importante nos resultados encontrados no uso da terapia ultra-sônica.

A literatura pesquisada por PARIZOTTO et al. (2003), não atendeu aos critérios mínimos estabelecidos na sua meta-análise, colocando em dúvida a relevância e confiabilidade dos resultados observados sobre as pesquisas de fonoforese. 
Segundo BYL (1995), aproximadamente $75 \%$ dos estudos de fonoforese relatam um efeito positivo da fonoforese, enquanto que outros obtiveram resultados negativos.

Acreditamos que os estudos que obtiveram resultados opostos ao nosso são possivelmente devido às falhas no processo de elaboração da pesquisa ou omissão de parâmetros que acreditamos ser importantes. Métodos mais confiáveis devem ser aplicados e de acordo com as condições tecnológicas atuais, já que muitos dos trabalhos realizados anteriormente, especialmente os mais antigos, não contavam com os recursos atuais e nem com as necessidades de informações requeridas na atualidade. $O$ desenvolvimento tecnológico tem gerado a possibilidade de medidas mais acuradas no âmbito da experimentação científica. No entanto, não podemos nos esquecer que os dados que temos hoje não devem ser desprezados, pois tem uma historicidade embutida, o que permitiu aos diversos investigadores chegarem a pensar nos problemas atuais com maior detalhamento.

Portanto, devemos considerar a construção histórica do conhecimento científico sobre o ultra-som e conseqüentemente a fonoforese, e utilizarmos as falhas metodológicas encontradas nos diversos trabalhos como interrogações para os trabalhos futuros.

O estabelecimento de métodos consistentes e a utilização dos recursos tecnológicos mais recentes devem ser uma meta a ser atingida nas próximas investigações sobre a fonoforese e ultra-som.

Portanto, pela análise de nossos resultados, o UST na modalidade pulsada à $100 \mathrm{~Hz}$ e regime de pulsação de $20 \%$ promove um efeito positivo no processo de reparação do tendão, e estando UST diretamente relacionado com 
a fonoforese, há indícios de que o UST induz a penetração transcutânea da hidrocortisona, pois os animais tratados com fonoforese são os que apresentaram os melhores resultados e a simples aplicação tópica de hidrocortisona não demonstrou haver influência, nas fases iniciais do processo de reparo tecidual em tendões de ratos. 


\section{CONCLUSÃO}

De acordo com a proposta e as condições específicas deste trabalho, os resultados nos permitem concluir que:

1) Há indícios de que o UST na modalidade pulsada à $100 \mathrm{~Hz} \mathrm{e}$ regime de pulsação de $20 \%$, induz a penetração transcutânea da hidrocortisona à 10\% na forma de gel tópico numa quantidade terapêutica.

2) Os animais tratados com fonoforese são os que apresentaram os melhores resultados, ou seja, foi o tratamento mais eficaz.

3) $O$ tratamento com aplicação tópica de hidrocortisona não demonstrou haver influência, nas fases iniciais do processo de reparo tecidual em tendões de ratos.

4) $\mathrm{O}$ tecido tendinoso, durante as fases iniciais do processo de reparo tecidual do tendão, respondeu à estimulação ultra-sônica.

5) O UST e a fonoforese na modalidade pulsada à $100 \mathrm{~Hz}$ e regime de pulsação de $20 \%$, demonstraram ser um método físico eficiente para a melhora da organização estrutural macromolecular do colágeno, uma vez que aceleraram o processo de reparo tendinoso, através da possível biomodulação da inflamação, da estimulação da proliferação fibroblástica e da síntese de colágeno no local da lesão; podê-se observar através da análise da 
birrefringência do colágeno um certo grau de concentração, estado de agregação, orientação e a deposição das fibras de colágeno no local da tenotomia, além da morfologia do crimp e do brilho característico.

6) Nenhum tratamento proposto desfavoreceu a estruturação normal que se desenvolve no sítio de lesão.

7) Os resultados fazem especular a possibilidade da utilização dos parâmetros da dosimetria, empregados na metodologia deste trabalho experimental, em situações clínicas.

8) Na qualidade de proposição para os futuros estudos, destacamos a necessidade de investigações da fonoforese sobre os diversos tipos de antiinflamatórios hormonais e não-hormonais. 


\section{REFERÊNCIAS BIBLIOGRÁFICAS}

ALLEN, K.G.R.; BATTYE, C.K. Performance of Ultrasonic Therapy Instruments. Physiotherapy, v. 64, n. 6, p. 174-179, 1978.

ALMEKINDERS, L.C., DEOL, G. The effects of aging, anti-inflammatory drugs, and ultrasound on the in vitro response of tendon tissue. The American Journal of Sports medicine, v. 27, n. 4, p. 417-421, 1999.

ALVES, J. M. Efeitos da energia ultra-sônica na regeneração da pele de animal com queimadura com calor. Dissertação Mestrado - Escola de Engenharia de São Carlos / Faculdade de Medicina de Ribeirão Preto, Universidade de São Paulo, 1988.

ASANO, J.; SUISHA, F.; TAKADA, M.; KAWASAKI, N.; MIYAZAKI, S. Effect os pulsed output ultrasound on the transdermal absorption of indomethacin from na ointment in rats. Biol Pharm Bull, v. 20, n. 3, p. 288-91, 1997.

BAKER, K. G.; ROBERTSON, V.J.; DUCK, F. A. A review of therapeutic ultrasound: biophysical effects. Physical Therapy, v. 81, p. 1351-1358, 2001.

BARANAUSKAS, V.; VIDAL, B. C.; PARIZOTTO, N. A. Observations os geometric structure os collagen molecules by atomic force microscop. Appl. Bichem. Biotech, v. 69, p. 91-96, 1998. 
BARE, A. C. et al. Phonophoretic Delivery of $10 \%$ hydrocortisone through the epidermis os humans as determined by serum cortisol concentration. Phys Ther. v. 76, p. 738-749, 1996.

BARNETT, S. B.; TER HAAR, G. R.; ZISKIN, M. C.; NYBORG, W. L.; MAEDA, K.; BANG, J. Current status of research on biophysical effects of ultrasound. Ultrasound in Med. \& Biol, v. 20, n. 3, p. 205-218, 1994.

BASSET, C.A.L.; BECKER, R.O. Generation of Electric Potentials by Bone in Response to Mechanical Stress. Science, v. 137, p. 1063-1064, 1962.

BASSET, C.A.L.. Pulsing Electromagnetic Fields. A New Method to Modify Cell Behavior in Calcified e Non-calcified Tissues. Calcified Tissue International, v. 34, p. $1-8,1982$.

BASURI, L.; LELE, P. P. A simple method for production of trackless focal lesion with focused ultrasound: statistical evaluation of the effects of irradiation on the central nervos system of the cat? J Physiol, v. 160, p. 513-534, 1962.

BENSON, H. A. E.; McELNAY, J. C. Topical non-steroidal antiinflammatory products as ultrasound couplants: their potential in phonophoresis. Physiotherapy, v. 80, n. 2, p. 74-6, 1994. 
BIRK, D.E.; TRELSTAD, R.L. Extracellular compartments in tendon morphogenesis: Collagen fibril, bundle, and macroaggregate formation. The Journal of Cell Biology, v. 103, p. 231-240, 1986.

BIRK, D.E.; ZYCBAND, E.I.; WINKELMANN, D.A.; TRELSTAD, R.L. Collagen fibrillogenesis in situ: fibril segments are intermediates in matrix assembly. Proc. Natl. Acad. Sci. USA, v. 86, p. 4549-4553, 1989.

BIRK, D.E.; ZYCBAND, E.I.; WOODRUFF, S.; WINKELMANN, D.A.; TRELSTAD, R.L. Collagen fibrillogenesis in situ: fibril segments become long fibrils as the developing tendon matures. Developmental Dynamics, v. 208, p. 291-298, 1997.

BISSCHOP, G.; BISSCHOP, E.; COMMANDRÉ, F. Eletrofisioterapia. $1^{\text {a }}$ edição em português. São Paulo, Livraria Santos Editora Com. Impr. Ltda, 2001.

BOMMANNAN, D., MENON, G. K., ELIAS, P. M.; GUY, R. H. Sonophoresis I The use of high-frequency ultrasound to enhance transdermal drug delivery. Pharm Res, v. 9, p. 559-563, 1992.

BRASILEIRO, J.; ALVES, T. C.; ESCÓSSIA, C. C. Análise da transmissibilidade ultra-sônica de medicamentos utilizados na prática da fonoforese. Rer. bras. fisoter., v. 7, n. 2, p. 139-144, 2003. 
BYL, N. N. The use of ultrasound as an enhancer for transcutaneus drug delivery: phonophoresis. Physical Therapy, v. 75, p. 481-488, 1995.

BYL, N. N., MCKENZIE, A., HALLIDAY, B. et al., The efeccts of phonophoresis with corticosteroids: A controlled pilot study. JOSPT, v. 18, n. 5, p. 590-600, 1993.

BYL, N.N.; McKENZIE, A.L.; WEST, J.M.; WHITNEY, J.D.; HUNT, T.K.; SCHEUENSTUHL, H.A. Low-Dose Ultrasound Effects on Wound Healing: A Controlled Study with Yucatan Pigs. Archive Physical Medicine Rehabilitation, v. 73, p. 656-664, 1992.

CAGNIE, B; VINCK, E; RIMBAUt, S; VANDERSTRAETEN, G. Phonophoresis versus topical application of ketoprofen: comparison betwwen tissue and plasma levels. Physical Therapy v. 83, n. 8, p. 707-712, 2003.

CAMERON, M. H.; MANROE, L. G. Relative transmission of ultrasound by media customarlly used of phonophoresis. Physical Therapy, v. 72, p. 142$148,1992$.

CASAROTTO, R.A. Agentes Acoplantes em Fisioterapia: Perdas Acústicas e Térmicas. Rev. Fisioter. Univ. São Paulo, v. 7, n.1/2, p. 34-35, 2000.

CETTI, R.; CHRISTENSEN, S.E.; EJSTED, R.; JENSEN, N.M.; JORGENSEN, U. Operative versus nonoperative treatment of Achilles tendon rupture- $A$ 
prospective randomized study and review of the literature. The American Journal of Sports Medicine, v. 21, n. 6, p. 791-799, 1993.

CHAN, B.P.; CHAN, K.M.; MAFFULLI, N.; WEBB, S.; LEE, K.K.H. Effect of basic fibroblast growth factor. Clinical Orthopaedics and Related Research, n. 342 , p. 239-247, 1997.

CHANG, J.; MOST, D.; THUNDER, R.; ALTO, P.; MEHRARA, B.; LONGAKER, M.T.; LINEAWEAVER, W.C. Molecular studies in flexor tendon wound healing: The pole of basic fibroblast growth factor gene expression. The Journal of Hand Surgery, v. 23A, n. 6, p. 1052-1058, 1998.

CICCONE, C. D.; WOLF, S.L. Pharmacology in rehabilitation. FA Davis Company, 1990.

CICCONE, D. C., LEGGIN, B. G.; CALLAMARO, J. J. Effects of ultasound and trolamine salicylatephonophoresis on delayed-onset muscle soreness. Physical Therapy, v. 71, n. 9, p. 666-674, 1991.

COAKLEY, W.T. Biophysical Effects of Ultrasound at Therapeutic Intensities. Physiotherapy, v. 64, n. 6, p. 166-169, 1978.

CONNER-KERR, T.; FRANKLIN, M.; KERR, J. et al. Phonophoretic delivery of dexamethasone to human transdermal tissue: a controlled pilot study. Eur $\mathbf{J}$ Phys Med Rehabil, v. 8, p. 8-19, 1998. 
CONOVER, W.J. Practical Nonparametric Statistics. John Wiley \& Sons, Second Edition, 1980.

CREPON, F. Eletrofisioterapia e Reeducação Funcional. São Paulo, Editora Lovise, 1996.

CHRISTINE, O. Y. NG; GABRIEL, Y. F. NG; EDWINA, K. N. SEE; MASON, C. P. LEUNG. Therapeutic ultrasound improves strength of Achilles tendon repair in rats. Ultrasound in Med. \& Biol. v. 29, n. 10, p. 1501-1506, 2003.

CULAW, E.M.; CLARK, C.H.; MERRILEES, M.J. Connective tissues: Matrix composition and its relevance to physical therapy. Physical Therapy, v. 79, n. 3, p. 308-319, 1999.

CUNHA, A., PARIZOTTO, N.A.; VIDAL, B.C. The effect of therapeutic ultrasound on repair of the achilles tendon (tendon calcaneus) of the rat. Ultrasound in Med. \& Biol., v. 27, n. 12, p. 1691-1691, 2001.

DAVID, R.; NISSAN, M.; COHEN, I.; SOUDRY, M. Effect of low-power He-Ne laser on fracture healing in rats. Lasers in Surgery and Medicine, v. 19, p. 458-464, 1996. 
DEMMINK, J. H.; HELDERS, P. J. M.; HOBEK, H.; ENWEMEKA, C. The variation of heating depth with therapeutic ultrasound frequency in physiotherapy. Ultrasound in Med. \& Biol., v. 29, n. 1, p. 113-118, 2003.

DOCKER, M. F., PATRICK, M. K.; FOULKES, D. J. Ultrasound couplants for physiotherapy. Physiotherapy, v. 68, n. 4, p. 124-125, 1982.

DOCKER, M.F. A revision of avilable instrumentation for ultrasound. Physiotherapy, v. 73, n. 4, p. 154-155, 1987.

DYSON, M. Non-Thermal Cellular Effects of Ultrasound. Br. J. Cancer, Suppl. v. 165 , p. 165-171. 1982.

DYSON, M. Ultrasound for Wound Management. In: GOGIA, P.P. Clinical Wound Management. 1. ed. EUA: SLACK Incorporated, p. 197-204, 1995.

DYSON, M. Mechanisms involved in therapeutic ultrasound. Physiotherapy, v. 73, n. 3, p. 116-120, 1987.

DYSON, M.; POND, J.B.; JOSEFH, J.; WARWICK, R. The Stimulation of Tissue Regeneration by Means of Ultrasound. Clinical Science, v. 35 , p. 273-285, 1968. 
DYSON, M.; SMALEY, D. Effects of Ultrasound on Wound Contraction. In: MILLER, R.; CORBET, U. Ultrasound Interactions in Biologic and Medicine. New York: Plenum Pressp. p. 151-158, 1983.

ENWEMEKA, C.S. Membrane-bound intracellular collagen fibrils in fibroblasts and myofibroblasts of regenerating rabbit calcaneal tendons. Tissue and Cell, v. 23 , n. 2, p. 173-190, $1991 b$.

ENWEMEKA, C.S. Connect tissue plasticity: ultrastructural, biomechanical, and morphometric effects of physical fators on intact and regenerating tendons. J. Orth. Sports Phys. Ther. v. 14, n. 5, p. 198-212, 1991 a.

ENWEMEKA, C.S. Functional Loading Augments the Initial Tensile Strenght and Energy Absorption Capacity of Regenerating Rabbit Achilles Tendons. Americam Journal of Physical Medicine and Rehabilitation, v. 7, n. 1, p. 3138, 1992.

ENWEMEKA, C.S. Inflamation, Cellurarity, and Fibrillogenesis in Regeneration Tendon: Implications for Tendon Rehabilitation. Physical Therapy, v. 69, p. 816-825, 1989a.

ENWEMEKA, C.S. The Effects of Therapeutic Ultrasound on Tendon Healing a Biomechanical Study. Americam Journal of Physical Medicine and Rehabilitation, p. 283-287, 1989b. 
ENWEMEKA, C.S.; REDDY, G.K.; BITTEL, L.S. Laser photostimulation of collagen production in healing rabbit achilles tendons. Lasers in Surgery and Medicine. v. 22, p. 281-287, 1998.

ENWEMEKA, C.S.; REDDY, K. The biological effects of laser therapy and other physical modalities on connective tissue repair processes. Laser Therapy. v. 12, p. 22-30, 2000.

ENWEMEKA, C.S.; RODRIGUEZ, O.; MENDOSA, S. The Biomechanicals Effects of Low Intensity Ultrasound on Healing Tendons. Ultrasound in Medicine and Biology, v. 16, n. 8, p. 801-807, 1990.

ENWEMEKA, C.S.; SPIELHOLZ, N.I. Modulation of Tendon Grouth and Regeneration by Eletrical Fields and Currents. In: CURRIER, D.P.; NELSON, R.M. Dynamics of Human Biologic Tissue. Philadelphia:. F. A . Davis Company, cap. 3, p. 231-254, 1992.

ENWEMEKA, C.S.; SPIELHOLZ, N.I.; NELSON, A.J. The Effect of Early Functional Activities on Experimentally Tendomized Achilles Tendons in Rats. Americam Journal of Physical Medicine and Rehabilitation, v. 67, n. 6, p. 264-269, 1988.

FALK, D.S.; BRILL, D.R.; STORK, D.G. Scattering and Polarization. In: Seeing the Light: Optics in Nature, Photography, Color, Vision and Holography. New York : Harper \& Row Publishers, cap. 13, p. 347-366, 1986. 
FANG, J. Y.; FANG, C. L.; SUNG, K.C.; CHEN, H. Y. Effect of low frequency ultrasound on the vitro percutaneous absorption of clobetasol 17-propionate. International Journal of Pharmaceutics, v. 9, p. 33-42, 1999.

FARRELL, J., THEIS, S., MITRAGOTRI, S., KOST, J.; LANGER, R. Mechanismis of ultrasound-mediated transdermal drug delivery. Annual Meeting of the acoustical Society of America, 1998.

FAY, B.; RINKER, M.; LEWIN, P.A. Thermostacoustic Sensor for Ultrasound Power Measurements and Ultrasonc Equipment Calibration. Ultrasound in Med. \& Biol, v. 20, n. 4, p. 367-373, 1994.

FELLINGER, K., SCHMID, J. Klinik und Therapie does Chronischen Gelenkhuematistus. Wien, p. 549-552, 1954.

FERRARI, A.L. Efeito da Interação do Ultra-Som com Sistemas Biológicos: Revisão da Literatura. Dissertação Mestrado - Escola de Engenharia de São Carlos / Faculdade de Medicina de Ribeirão Preto, 1987.

FRENKEL, V; KIMMEL, E.; IGER, Y. Ultrasound-induced cavitation damage to external epithelia of fish skin. Ultrasound in Med \& Biol., v. 25, n. 8, p. 1295303, 1999. 
FRIZZEL, L. A.; LINKE, C. A.; CARSTENSEN, L.; FRIDD, C.W. Thresholds for focal ultrasonic lesions in rabbit kidney, liver, and testicle. IEEE Trans Biomed Eng BME, v. 24, p. 393-396, 1977.

FUKADA, E.; YASUDA, I. On the Piezoelectric Effect of Bone. Journal of the Physical Society of Japan, v. 10, p. 1158-1169, 1957.

FYFE, M. C.; PARNELL, S. M. The effective transducer radiating in the testing and calibration of therapheutic ultrasonic instruments. Health Phys, v. 43, n. 3, p. 377-381, 1982.

FYFE, M.C.; CHAHL, L.A. Mast Cell. Degranulation: A Possible Mechanism of Action of Therapeutic Ultrasound. Ultrasound in Med \& Biol., v. 8 (Suppl): n. 62, 1982.

GAM, A. N.; JOHANNSEN, F. Ultrasound therapy in musculoskeletal disorders: a meta-analysis. Elsever Science B V, v. 63, p. 85-91, 1995.

GAN, B.S.; HUYS, S., SHEREBRIN., M.H.; SCILLEY, C.G. The Effects of Ultrasound Treatment on Flexor Tendon Healing in the Chicken Limb. Journal of Hand Surgery, v. 20B, n. 6, p. 809-814, 1995.

GELBERMAN, R.H.; VANDEBERG, J.S.; MANSKE, P.R.; AKESON, W.H. The early stages of flexor tendon healing: a morphologic study of the first fourteen days. The Journal of Hand Surgery, v. 10A, n. 6, p. 776-784, 1985. 
GIGANTE, A.; SPECCHIA, N.; RAPALI, S.; VENTURA, A.; DE PALMA, L. Fibrilllogenesis in tendon healing: on experimental study. J. Biol. Res. v. 7, n. 8, p. 203-210, 1996.

GILMAN, A. G et al. The pharmacological basis of therapeutics, $9^{\text {th }}$ ed. W. B. Saunders: Philadelphia, PA, 1999.

GOGIA, P.P. Phisiology of Wound Healing. In: Clinical Wound Management. 1.ed. United States of America: SLACK Incorporated, cap. 1, p. 1-12, 1995.

GRIFFIN, J.E.; TOUCHSTONE, J.C. Low-intensity phonophoresis of cortisol in swine. Physical Therapy, v. 48, p. 1336-1344, 1968.

GRIFFIN, J.E., ECHTERNACH, J.L., PRICE, R.E.; TOUCHSTONE, J.C. Patients to with ultrasonic-driven hydrocortisoneand with ultrasound alone. Physical Therapy, v. 47, p. 594-601, 1967.

GUERINO, M.R., LUCIANO, E.; GONÇALVES, M.; LEIVAS, T.P. Aplicação de Ultra-Som Pulsado Terapêutico Sobre a Resistência Mecânica na Osteotomia Experimental. Revista Brasileira de Fisioterapia, v. 2, n. 2, p. 63-66, 1997.

GUIRRO, R.; SANTOS, S. C. B. A realidade da potência acústica emitida pelos equipamentos de ultra-som terapêutico: uma revisão. Rev. Fisiot. Univ. São Paulo, v. 4, n. 2, p. 76-82, 1997. 
GUN, S.L.; KESANA, G.R.; BITTEL, L.S.; ENWEMEKA, C.S. Combined Ultrasound, Electrical Stimulation, and Laser Promote Collagen Syntesis with Moderate Chances in Tendon Biomechanics. Americam Journal of Physical Medicine \& Rehabilitation, v. 76. n. 4, p. 289-295, 1997.

HARVEY, W.; DYSON, M.; POND, J.; GRAHAME, R. The in vitro Stimulation of Protein Synthesis in Human Fibroblasts by Therapeutic Levels of Ultrasound. In: MAXWELL, L. Therapeutic Ultrasound: Its Effects on the Cellular and Molecular Mechanisms of Inflamation and Repair. Physiotherapy, v. 78, n. 6, 1992.

HASHISH, I.; HAI, H. K.; HARVEY, W.; FEINMANN, C.; HARRIS, M. Reduction of post-operative pain and swelling by ultrasound tratament: A placebo effect. Pain, v. 33, p. 303-311, 1988.

HASHISH, I.; HARWEY, W.; HARRIS, M. Anti-inflammatory effects of ultrasound therapy: evidence for a major placebo effect. Br J Rheumatol, v. 25, p. 77-81, 1986.

HECHT, E. Óptica. Tradução e Prefácio: Rebordão, J.M.N.V. 2 ed: Fundação Calouste Gubelkain, cap. 8, p. 282-346, 1991.

HILL, C. R. Ultrasonic exposure threshold for changes in cells and tissues. The Journal of the Acoustical Society of America, v. 52, n. 2, p. 667-672, 1972. 
HIRANUMA, K.; SUZUKI, K,; HIRATA, K.; NAKAMURA, H.; HIGASHI, K.; HIRANO, H. Extracellular matrices in peritendinous connective tissue after surgical injury to the chicken flexor tendon. Arch Orthop Trauma Surg, v. 115, p. 63-67, 1996.

HOLDSWORTH, L.K.; ANDERSON, D. M. Efectiveness of ultrasound used with a hydrocortisone coupling medium or epicondylitis clasp to treat lateral epicodylitis: Pilot study. Physiotherapy, v. 79, n. 1, p. 19-24, 1993.

HOLLENSHEAD, W. H. Livro Texto de Anatomia Humana. 3. ed. São Paulo: Harbra - Harper \& Row do Brasil, 1990.

HOOGLAND, R. Terapia Ultra-Sônica. Espanha: Enraf Nonius Delft, 1986.

JACKSON, B. A.; SCHWANE, J.A.; STARCHER, B. C. Effect of Ultrasound Therapy on The Repair of Tendon Injuries in Rats. Medicine and Science in Sports and Exercise, v. 23, n. 2, p. 171-176, 1990.

JÓZSA, L.; KANNUS, P. Human Tendons. United States of America: Human Kinetics, 1997.

JUNQUEIRA, L.C.U.; CARNEIROJ.S.F. Histologia Básica. 7. ed. Rio de Janeiro: Guanabara Koogan, 1990. 
KAKAR, S.; KHAN, U.; McGROUTHER, D.A. Differential cellular response within the rabbit tendon unit following tendon injury. The Journal of Hand Surgery, v. 23B, n. 5, p. 627-632, 1998.

KANNUS, P.; JÓZSA, L. Histopathological changes preceding spontaneous rupture of a tendon - A controlled study of 891 patients. The Journal of Bone and Joint Surgery, v. 73-A, n. 10, p. 1507-1525, 1991.

KHAN, K.M.; COOK, J.L.; BONAR, F.; HARCOURT, P.; ASTROM, M. Histopathology of commom tendinopathies. Injury Clinic, v. 27, n. 6 , p. $393-$ 408, 1999.

KITCHEN, S.S.; PATRIGE, C.J. A Review of Therapeutic Ultrasound Part 1: Background and Physiological Effects. Physioterapy, v. 76, n. 10, p. 593-599, 1990.

KLAIMAN, M.D.; SHRADER, J.A.; DANNOFF, J.V.; HICKS, J.E.; PESCE, W.J.; FERLAND, J. Phonophoresis versus ultrasound in the tratment of common musculoskletal conditions. Medicine and Science in Sports and Exercise, v. 30, n. 9, p. 1349-1355, 1998.

KLEINKORT, J.A.; WOOD, F. Phonophoresis with 1 percent vers 10 percent hydrocortisone. Physical Therapy, v. 55, p. 1320-1324, 1975. 
KURTZ, R.C.; ALMEIDA, A.L.; APFEL, M.R.; ELIAS, N.; MESQUITA, K.C. Cicatrização nas lesões agudas do tendão calcâneo - estudo experimental comparativo entre tratamento conservador e cirúrgico. Rev Bras Ortop, v. 31, n. 10 , p. $857-861,1996$.

KUSCHNER, S.H.; ORLANDO, C.A.; MCKELLOP, H.A.; SARMIENTO, A. A comparison of the healing properties of rabbit Achilles tendon injuries at different levels. Clinical Orthopaedics and Related Research, n. 272, p. 268273, 1991.

LEHMANN, J.F. Ultrasonic diathermy. In: KRUSEN, F.H., KOTTKE, F.J., \& ELLERWOOD, P., ed. Handbook of physical medicine and rehabilitation, Philadelphia and London, W.B. Saunders Co., p. 271-299, 1965.

LEHMANN, J.F.; DE LATEUR, B.J. Diatermia e Calor Superficial, Laser e Crioterapia. In: KOTTKE, F.J.; LEHMANN, J.F. Tratado de Medicina Física e Reabilitação de KRUSEN. 4. ed. Rio de Janeiro: Manole Ltda, 1994.

LOW, L.; REED, A. Eletroterapia Explicada: Princípios e Prática. $3^{\mathrm{a} e d .}$ Barueri-SP: Manole, 2001.

LUNDBORG, G.; RANK, F.; HEINAU, B. Intrinsic tendon healing: a new experimental model. Scand J Plast Reconstr Surg, v. 19, p. 113-117, 1985. 
MANSKLE, P.R.; LESKER, B.S. Histologic evidence of intrinsic flexor tendon repair in various experimental animals: an in vitro study. Clinical Orthopaedics and Related Research, n. 182, p. 297-304, 1984.

MANSKLE, P.R.; LOUIS, S.T.; GELBERMAN, R.H.; VANDE BERG, J.S. Intrinsic flexor-tendon repair: a morphological study in vitro. The Journal of Bone and Joint Surgery, v. 66-A, n. 3, p. 385-389, 1984.

MARINO, A.A.; BECKER, R.O. Piezo-Electric Effect e Growth Control in Bone. Nature, v. 228, p. 473, 1970.

MAXWELL, L. Therapeutic Ultrasound: Its Effects on the Cellular and Molecular Mechanisms of Inflamation and Repair. Physiotherapy, v. 78, n. 6, p. 421-425, 1992.

MAYNE, R. The Differents Types of Collagen and Collagenous Peptides. In: The Role of Extracelular Matrix in Development. New York: Alan R. Liss, p. 33-42, 1984.

MCCABE, M.; PYE, S. Therapeutic Ultrasound: Risk Associated with Poor Calibration. Physioterapy, v. 83, n. 5, p. 228, 1997.

MCDIARMID, T; BURNS, P. N. Clinic application of therapeutic ultrasound. Physioterapy, v. 73, n. 4, p. 155-162, 1987. 
MCELNAY, J.C.; BENSON, H. A. E.; HADGRAFT, J.; MURPHY, T.M. The use of ultrasound in skin penetration enhancement. In walters, KA and Hadgraft, J (Eds). Pharmaceutical skin penetration enhanced, Marcel Dekker, New York: p. 293-309, 1993.

MCELNAY, J.C.; MATTHEWS, M. P.; HARLAND, R.; MC CAFFERTY, D. F. The effect of utrasound on the percutaneous absorption of lignocaine. $\mathbf{B r} \mathbf{J}$ Cin Pharmacol, v. 20, p. 421-424, 1985.

MCNEILLY, C.M.; BANES, A.J.; BENJAMIN, M.; RALPHS, J.R. Tendon cells in vivo form a three dimension network of cell processes linked by gap junctions. J. Anat., v. 189, p. 593-600, 1996.

MEIDAN, V. M.; WALMSLEY, A. D.; DOCKER, M.F.; IRWIN, W.J. Ultrasoundenhanced diffusion into coupling gel during phonophoresis of 5-fluorouracil. International Journal of Pharmaceutics, v. 185, p. 205-213, 1999.

MELLO, M. L. S.; VIDAL, B. C. Experimental tendon repair: glycosaminoglycan arrangement in newly synthesized collagen fibers. Cell. Mol. Biol., v. 49, n. 4, p. $579-585,2003$.

MELLO, M.L.; GODO, C.; VIDAL, B.C.; ABUJADI, J.M. Changes in Macromolecular Orientational on Collagen Fibers During the Process of Tendon Repair in the Rat. Ann. Histochim, v. 20 , p. 145-152, 1975. 
MILLER, M.W. Gene Transfection and Drug Delivery. Ultrasound in Med. \& Biol, v. 26, n. 1, p. 59-62, 2000.

MIMNI, M.E.; HARKNESS, R.D. Molecular Structures and Functions of Collagen. In: MIMNI, M.E. Collagen. CRC Press, Inc. Boca Raton, Florida: p. 01-77, 1988.

MITRAGOTRI, S.; BLANKSCHTEIN, D.; LANGER, R. Ultrasound-mediated transdermal protein delivery. Science, v. 269, p. 850-853, 1995a.

MITRAGOTRI, S.; BLANKSCHTEIN, D.; LANGER, R. An explanation for the variation of the sonophoretic transdermal transport enhacement fron drug to drug. J. Pharmaceutic Sci, v. 86, p. 1990-1192, 1997.

MITRAGOTRI, S.; BLANKSTEIN, D.; LANGER, R. Transdermal drug delivery using lowfrequency sonophoresis. Pharm Res, v. 13, p. 411-420, 1996.

MITRAGOTRI, S.; EDWARDS, D.A.; BLANKSTEIN, D.; LANGER, R. A. Mechanistic study of ultrasound-enhanced trandermal drug delivery. J Pharm Sci, v. 84, p. 697-706, 1995b.

MITRAGOTRI, S.; FARREL, J.; TANG, H.; TERAHARA, T.; KOST, J.; LANGER, R. Determination of threshold energy dose for ultrasound-induced transdermal drug transport. Elsevier Science B V, v. 43, p. 41-52, 2000. 
MÜLLER, M.; MASCHER, H.; KIKUTA, C.; SCHAFER, S.; BRUNNER, M.; DORNER, G.; EICHLER, H. Diclofenac concetrations in defined tissue layers after topical administration. Clin Pharmacol Ther., v. 62, n. 3, p. 293-9, 1997.

NOVAK, E.J. Experimental Transmission of lidocaine through intact skin by ultrasound. Arch Phys Med, v. 45, p. 231-232, 1964.

OAKLEY, E.M. Aplication of continuous beam ultrasound at therapeutic levels. Physioterapy, v. 68, n. 8, p. 169-172, 1978.

OLIVEIRA, M. F. Resposta do tecido pulpar à aplicação da pasta à base de hidróxido de cálcio precedida do emprego do curativo de corticosteróide ou corticosteréide/antibiótico. Estudo histológico em dentes de ratos. Araraquara, Dissertação (Mestrado em Odontopediatria) - Faculdade de Odontologia, Universidade Estadual Paulista, 2000.

PARIZOTTO, N. A. Ação do Laser de Hélio-Neônio sobre o Processo de Reparo Tecidual: Um Estudo do Colágeno por Microscopia Eleltrônica de Varredura, Microscopia de Varredura, Microscopia de Força Atômica e Espectroscopia por Infravermelho. Tese de Doutorado, Faculdade de Engenharia Elétrica e de Computação, Universidade Estadual de Campinas, 1998. 
PARIZOTTO, N. A.; KOEKE, P. U.; MORENO, B. G. D.; LOURENCIN, F. T. C. Utilização da fonoforese em desordens músculo-esquelética: uma metaanálise. Rev bras. fisioter. v. 7, n. 1, p. 49-55, 2003.

PARKINSON, J.; BRASS, A.; CANOVA, G.; BRECHET, Y. The mechanical properties of simulated collagen fibrils. J. Biomechanics, v. 30 , n. 6 , p. 549$554,1997$.

PEREIRA, F.E.L. Degenerações. Morte Celular. Alterações do Interstício. In: BOGLIOLO, Patologia. 5. ed. Rio de Janeiro: Guanabara Koogan, p. 47-81, 1994.

PIMENTEL, E.R. Form Birrefringence of Collagen Bundles. Acta Histochem. Citochem, v. 14, n. 1, p. 35-40, 1981.

PLAPLER, P.G.; CAMANHO, G.L.; SALDIVA, P.H.N. Avaliação numérica das ondulações das fibras colágenas em ligamento patelar humano (tendão patelar). Rev. Bras. Ortop. v. 36, n. 8, p. 317-321, 2001.

POSTACCHINI, F.; DE MARTINO, C. Regeneration of Rabbit Calcaneal Tendon: Maturation of Collagen an Elastic Fibers Following Partial Tenotomy. Connective Tissue Research, v. 8, p. 41-47, 1980. 
PUDDU, G.; IPPOLITO, E.; POSTACCHINI, F. A classification of Achilles tendon disease. The American Journal of Sports Medicine, v. 4, n. 4, p. 145150, 1976.

RABINOWITZ, J. L.; FELDMAN, E. S.; WEINBERGER, A.; SCHUMACHER, H, R. Comparative tissue absorption of oral aspirin and topical triethanolamine salicylate in human and canine knee joints. J Clin Pharmacol., v. 22, p. 42-48, 1988.

RAMIREZ, A.; SCHWANE, J.A.; McFARLAND, C.; STARCHER, B. The Effects of Ultrasound on Collagen Synthesis and Fibroblast Proliferation in vitro. Medicine and Science in Sports and Exercise, p. 326-332, 1996.

REDDY, G.K.; CHILDS, E.; OGLE, A.; ENWEMEKA, C.S.; STEHNO-BITTEL, L. The effects of laser stimulation on wound healing in diabetic rats. In: Proceeding $2^{\text {nd }}$ Congress World Association for Laser Therapy. Kansas City, Missouri, USA, September 2-5, p. 124-125, 1998a.

REDDY, G.K.; GUM, S.; STEHNO-BITTEL, L.; ENWEMEKA, C.S. Biochemistry and biomechanics of healing tendon: Part II. Effects of combined laser therapy and electrical stimulation. Medicine \& Science in Sports \& Exercise, p. 794800, 1998b. 
REDDY, G.K.; STEHNO-BITTEL, L.; ENWEMEKA,C.S. Laser photostimulation accelerates wound healing in diabetic rats. Wound Repair and Regeneration, v. 9 , n. 3, p. $248-255,2001$.

REED, B.; ZARRO V. Inflamation and Repair na the Use of Thermal Agents. In: MICHLOVITZ, S. L. Thermal Agents in Rehabilitation. 2. Ed. Philadelphia: F. A . Davis Company, p. 3-17, 1990.

REID, D.C.; CUMMINGS, G. E. Efficiency of ultrasound counpling agents. Physiotherapy, v. 63, n. 8, p. 255-257, 1977.

REYNOLDS, N.L.; WORRELL, T.W. Chronic Achilles peritendinitis: etiology, pathophysiology, and treatment. JOSPT, v. 13, n. 4, p. 171-176, 1991.

ROBERTS, M.; RUTHERFORD, J.H.; HARRIS, D. The Effect of Ultrasound on Flexor Tendon Repairs in the Rabbit. The Hand, v. 14, n. 1, p. 17-20, 1982.

ROBERTSON, V.J.; BAKER, K.G. A review of therapeutic ultrasound: effectiveness studies. Physical Therapy, v. 81, p. 1339-1350, 2001.

ROSIM, G. C. Análise da influência do ultra-som terapêutico na penetração transcutânea de diclofenaco sódico em humanos sadios. Dissertação de Mestrado- Escola de Engenharia de São Carlos / Faculdade de Medicina de Ribeirão Preto / Instituto de Química de São Carlos, Universidade de São Paulo, 2003. 
RUSSELL, J.E.; MANSKLE, P.R. Collagen synthesis during primate flexor tendon repair in vitro. Journal of Orthopaedic Research, v. 8, p. 13-20, 1990.

SAINI, N.S.; ROY, K. S.; BANSAL, B.; SINGH, B.; SIMRAN, P. S. A preliminary study on the effect of ultrasound therapy on the healing of surgically severed Achilles tendons in five dogs. J. Vet. Med, v. 49, p. 321-328, 2002.

SALOMÃO, O.; CARVALHO, A.E.; FERNANDES, T.D.; FILHO, I.H.T.; NETO, J.C. Lesões tendíneas no pé e no tornozelo do esportista. Rev. Bras. Ortop.; v. 28, n. 10, p. 731-736, 1993.

SANTANDER, R.G.; ARRIBA, M.A.P.; CUADRADO, G.M.; ALONSO, A.L.; MARTINEZ, M.G.S.; ALONSO, F.J.M.; MONTEAGUDO, M.; LOBO, M.V.T. Intracellular biogenesis of collagen fibrils in 'activated fibroblasts' of tendo achilles. The Journal of Bone and Joint Surgery, v. 81, p. 522-530, 1999.

SILVA, O.L. Estudo do Mecanismo de Ação do Ultra-Som na Estimulação de Crescimento Ósseo. Dissertação de Mestrado, Escola de Engenharia de São Carlos - Universidade de São Paulo, 1987.

SMITH, N. B.; LEE, S.; MAIONE, E.; ROY, R. B.; MCELLIGOTT, S.; SHUNG, K. K. Ultrasound-mediated transdermal transport of insulin in vitro through human skin using novel transducer, Ultrasound in Med \& Biol., v. 29, n. 2, p. 311-317, 2003. 
SOMA, C.A.; MANDELBAUM, B.R. Repair of acute achilles tendon ruptures. Orthopedic Clinics of North America, v. 26, n. 2, p. 239-247, 1995.

STARKEY, C. Ultrasound In: Therapeutic Modalities. 2. Ed. Philadelphia: F.A. Davis, cap 6, p. 269-302, 1999.

STEHNO-BITTEL, L.; REDDY, G.K.; GUN, S.; ENWEMEKA, C.S. Biochemistry and Biomechanics of Healing Tendon: Part I. Effects of Rigid Plaster Casts and Functional Casts. Medicine and Science in Sports na Exercise, v. 30, n. 6, p. 788-793, 1998.

STEVENSON J.H; PANG C.Y.; LINDSAY W.K.; ZUKER R.M.. Functional, Mechanical and Biochemical Assessment of Ultrasound Therapy on Tendon Healing in the Chicken Toe. Plastic and Reconstrutive Surgery, v. 77, n. 6, p. 965-971, 1986.

STEWART, H. F.; HARRIS, G.R.; HERMAN, B.A.; ROBINSON, R.A.; HARAN, M. E.; MC CALL, G. R.; CARLESS, G.; REES, D. Surfey of use and performace of ultrasonic therapy equipament in pinellas county. Florida. Physical Therapy, v. 54, p. $707-715,1974$.

STOLINSKI, C. Disposition of collagen fibrils in human tendons. J. Anat., v. 186, p. 577-583, 1995. 
SWIST-CHMIELEWSKA et al. Experimental selection of best physical and application parameters of ultrasound in the treatment of venous crural ulceration. Pol Merkuriusz Lek, v. 12, n.72, p. 500-5, 2002.

TACHIBANA, K.; TACHIBANA, S. Application of ultrasound energy as a new drug delivery system. Japan J Applied Physics, v. 38, n. 5B, p. 3014-3019, 1999.

TER HAAR, G. Basic Physics of Therapeutic Ultrasound. Physiotherapy, v. 73, n. 3, p. 110-113, 1987.

TER HAAR, G. Basic physics of therapeutic ultrasound. Physioterapy, v. 64, n. 4, p. 100-104, 1978.

TILLMAN, L.J.; CUMMINGS G.S. Remodeling of Dense Connective Tissue in Normal Adult Tissues. In: CURRIER, D.P.; NELSON, R.M. Dynamics of Human Biologic Tissue. Philadelphia: F. A . Davis Company, cap. 2, p. 45-69, 1992b.

TILLMAN, L.J.; CUMMINGS, G.S. Biologic Mechanisms of connective Tssue Mutability. In: CURRIER, D.P.; NELSON, R.M. Dynamics of Human Biologic Tissue, Philadelphia: F. A . Davis Company, cap. 1, p. 1-41, 1992a. 
TURNER, S.M.; POWELL, E.S.; NG, C.S.S. The Effects of Ultrasound on the Healing of Repaired Cockerel Tendon: is Collagen Crosslinkge a Factor? Journal of Hand Surgery, v. 14B, p. 428-433, 1989.

TYLE, P.; AGRAWALA, P. Drug delivery by phonophoresis. Pharm Res, v. 6, p. 355-361, 1989.

UEDA, H.; OGIHARA, M.; SUGIBAYASHI, K.; MORIMOTO, Y. Change in the Electrochemical Properties of Skin and the Lipid Packing in Stratum Corneum by Ultrasonic Irradiation. Int. J. Pharm, v. 137, p. 217-224, 1996.

UEDA, H.; OGIHARA, M.; SUGIBAYASHI, K.; MORIMOTO, Y. Change in the Electrochemical Properties of Skin and the Lipid Packing in Stratum Corneum by Ultrasonic Irradiation. Int. J. Pharm, v. 137, p. 217-224, 1996a.

UEDA, H.; OGIHARA, M.; SUGIBAYASHI, K.; MORIMOTO, Y. Diference in the enhancing effects of ultrasound on the skin permeation of polar and non-polar drugs. Chem Pharm Bull, v. 44, p. 1973-1976, 1996b.

VAN DER WINDT, D. A, W, N.; VAN DER HEIJDEN, G. J. M. G.; VAN DER BERG, S. G. et al. Ultrasound therapy for musculoskeletal disorders: a systematic review. Pain, v. 81, p. 257-271, 1999.

VIDAL, B. C. The part played by the mucopolysaccharides in the form birefringence of collagen. Protoplasma, v. 59, p. 472-479, 1964. 
VIDAL, B. C.; CARVALHO, H. F. Agregational State an Molecular Order of Tendons as a Function of Age. Matrix, v. 10, p. 48-57, 1990.

VIDAL, B. C.; MELLO, M. L. S.; GODO. C.; CASEIRO, A. C.; ABUJADI, J. M. Anisotropic Properties of Silver Plus Fod - Impregnated Collagen Bundles ADB and Form Birrefringence Curves. Ann. Histochim, v. 20, p. 15-26, 1975.

VIDAL, B.C. Cell. and Extracellular Matrix Interaction: A Feed-back Theory Based on Molecular Order Recognition - Adesion Events. Revista FCM. UNICAMP, v. 4, n. 11, 1994.

VIDAL, B.C. Crimp as Part of a Helical Struture. Life Sciences Biochemistry, v. 318, p. $173-178,1995 a$.

VIDAL, B.C. Evaluation of the Carbohydrate Role in the Molecular Order of Collagen Bundles: Microphotomentric Measurenents of Textural Birrefringence. Cellular and Molecular Biology, v. 32, n. 5, p. 527-535, 1986.

VIDAL, B.C. From Collagen Type I Solution to Fibers with a Helical Pattern: A Self - Assembly Phenomenon. Life Sciences Biochemistry, v. 318, p. 831836, $1995 b$.

VIDAL, B.C. Image analysis of tendon helical superstructure using interference and polarized light microscopy. Micron, v. xx, n. xx, p. 1-10, 2003. 
VIDAL, B.C. Macromolecular Desorientation in Deteched Tendons. Protoplasma, p. 122-132, 1966.

VIDAL, B.C. Matrix Extracelular. In: VIDAL, B.C.; MELLO, M.L.S. Biologia Cellular, Rio de Janeiro e São Paulo: Livraria Atheneu, p. 273-304, 1987a.

VIDAL, B.C. Métodos em Biologia Celular. In: VIDAL, B.C.; MELLO, M.L.S Biologia Celular. Rio de Janeiro e São Paulo: Atheneu, p. 5-40, 1987b.

VILLARTA, R.; VIDAL, B.C. Anisotropic and Biomechanical Properties of Tendons Modified by Exercise and Denervation: Aggregation and Macromolecular Order in Collagen Bundles. Matrix, v. 9, p. 55-61, 1989.

VOGEL, H.G. Correlation Betwen Tensile Strengt and Collagen Content in Rat Skin. Effects of Age and Cortisol Treatment. Connective Tissue Research, v. 2, n. 177, 1974.

WARDEM, S. J. A new direction for ultrasound therapy in sport medicine. Sports Med, v. 33, n. 2, p. 95-107, 2003.

WARDEN, S. J.; MCMEEKEN, J. M. Ultrasound usage and dosage in sports physiotherapy. Ultrasound in Med \& Biol., v. 28, n. 8, p. 1075-1080, 2002. 
WEIMANN, L. J.; WU, JUNRU. Transdermal delivery os poly-l-lysine by sonomacroporation. Ultrasound in Med \& Biol., v. 28, n. 9, p. 1173-1180, 2002.

WELLS, P.N.T. Biomedical ultrasonics, London, Academic Press, 1977.

WHITTAKER, E.; CANHAM, P.B. Demonstration of Quantitative Fabric Analysis of Tendon Collagen Using Two-Dimensional Polarized Light Microscopy. Matrix, v. 11, p. 56-62, 1991.

WILLIANS, A.R. Production and Transmission of Ultrasound. Physiotherapy, v. 73, n. 3, p. 113-116, 1987.

WING, M. Phonophoreis with hydocortisone in the tratament of temporomandibualr joint dysfunction. Physical Therapy, v. 62, n. 1, p. 32-33, 1982.

WU, J.; CHAPPELOW.; YANG, J.; WEIMANN, L.. Defects generated in human stratum corneum specimens by ultrasound. Ultrasound in Med \& biol., v. 24, n. 5, p. 705-10, 1998.

YASUDA, I. On the Piezo-Electric Activity of Bone. Journal of the Japanese Orthopaedic Surgical Society, v. 28, p. 267, 1954. 
YOUNG, S.R.; DYSON, M. The Effect of Therapeutic Ultrasound on Angiogênesis. Ultrasound in Med. \& Biol, v.16, n. 3, p. 261-269, 1990a.

YOUNG, S.R.; DYSON, M., Macrophage Responsiveness to Therapeutic Ultrasound. Ultrasound in Med. \& Biol, v. 16, n. 8, p. 809-816, 1990 b.

ZEQIRI, B. Calibration and Safety of Physioterapy Ultrasound Equipment. Physiotherapy, v. 83, n. 10, p. 559-560, 1997.

ZISKIN, C.M.; NcDIARMID, T.; MICHLOVITZ, S.L. Therapeutic Ultrasound. In: MICHLOVITZ, S.L. Thermal Agents in Rehabilitation. 3. Ed. Philadelphia: F. A . Davis Company, p. 169-207, 1999. 


\section{ANEXOS}

\section{Anexo A}

\section{Análise de variância}

Em um primeiro momento a intenção era realizar uma ANOVA, entretanto isso não foi possível, pois os grupos não apresentem homogeneidade de variância, como demonstra os testes abaixo:

\section{Saídas do Minitab}

Bartlett's Test (normal distribution)

Test Statistic: 11,477

P-Value : 0,022

Levene's Test (any continuous distribution)

Test Statistic: 3,225

P-Value $: 0,024$

Ou seja para qualquer um destes testes rejeitamos a igualdade de variância entre os grupos pois temos valores pequenos de $p$-value ( $p$ valor). 
Após essa constatação o procedimento foi utilizar o teste não paramétrico de Kruskal-Wallis para efetuar a comparação entre os 5 grupos em relação à medida de birrefringência. 


\section{Anexo B}

\section{O teste de Kruskal-Wallis.}

Os dados de todos os grupos são juntados em um único conjunto e ordenados em ordem crescente. Ao menor valor é atribuído o posto 1, ao próximo valor é atribuído o posto 2 e assim por diante até último valor. Quando ocorrem empates entre os valores, considera-se como seus postos a média dos postos que lhes seriam atribuídos se fosse colocado um em seguida do outro. Em seguida, os valores dos dados dentro de cada grupo são substituídos pelos seus postos e em cada grupo são realizadas as somas dos postos correspondentes.

Por exemplo, para os dados das tabela 1 obtém-se:

TABELA 4 - Postos das médias das medições da birrefringência

\begin{tabular}{lrrrrr}
\hline RATO & GRUPO1 & GRUPO2 & GRUPO3 & GRUPO4 & GRUPO5 \\
\hline 1 & 37 & 3 & 1 & 19 & 25 \\
2 & 40 & 10 & 7 & 26 & 28 \\
3 & 33 & 14 & 16 & 27 & 31 \\
4 & 34 & 15 & 5 & 21 & 29 \\
5 & 36 & 9 & 2 & 22 & 32 \\
6 & 38 & 12 & 4 & 24 & 30 \\
7 & 39 & 8 & 13 & 18 & 23 \\
8 & 35 & 11 & 6 & 17 & 26 \\
\hline \multirow{2}{*}{ Média } & 36.5 & 10.25 & 6.75 & 21 & 28 \\
\end{tabular}

Observa-se que as medições do grupo controle 1 possuem os maiores postos, o que significa que apresenta os maiores valores de birrefringência; 
seguido pelos grupos 5 e 4 . O grupo 3 é o que apresenta a menor magnitude dos seus postos, em seguida aparece o grupo 2, sendo esses 2 grupos os mais afastados do grupo 1.

A estatística de teste é definida como:

$$
T=\frac{1}{S^{2}}\left(\sum_{i=1}^{k} \frac{R_{i}^{2}}{n_{i}}-\frac{N(N+1)^{2}}{4}\right)
$$

(1)

onde: $\quad R_{i}$ é a soma dos postos no i-ésimo grupo;

$n_{i}$ é a quantidade de postos dentro do grupo i (aqui, igual a 8 em todos os grupos),

$\mathrm{N}$ é a quantidade de postos em todos os grupos comparados (aqui, igual a $5 \times 8=40$ ), e

$$
\mathrm{S}^{2} \text { é determinado por: }
$$

$$
S^{2}=\frac{1}{N-1}\left(\sum_{\text {todos-os-postos }} R\left(X_{i j}\right)^{2}-\frac{N(N+1)^{2}}{4}\right)
$$

(2)

$$
R\left(X_{i j}\right)^{2} \text { é a soma de todos os postos elevada ao quadrado }
$$

Quando a hipótese $\left(\mathrm{H}_{0}\right)$ de igualdade entre os grupos (populações) é rejeitada, então existe, no mínimo, dois grupos que diferem entre si. Para determinar quais são estes grupos pode-se usar o seguinte procedimento:

Obs.: Rejeita-se $H_{0}$ quando o $p$ valor é menor que o nível de significância adotado. 


\section{Anexo C}

\section{Teste de comparações múltiplas.}

Se para dois grupos i e j ocorrer:

$$
\left|\frac{R_{i}}{n_{i}}-\frac{R_{j}}{n_{j}}\right|>t_{1-\left(\frac{\alpha}{2}\right)}\left(S^{2} \frac{N-1-T}{N-k}\right)^{\frac{1}{2}}\left(\frac{1}{n_{i}}+\frac{1}{n_{j}}\right)^{\frac{1}{2}},
$$

(3)

onde: $R_{i}$ e $R_{j}$ são as somas dos postos dos correspondentes grupos e $t_{1-(\alpha / 2)}$ é o percentil que acumula uma área abaixo de (1- $\left.\alpha / 2\right) \%$ (por exemplo, ao nível de $5 \%$ de significância, $\alpha=0,05$ e (1-0,05/2)\%=97,5\%) sob a curva da distribuição $t$ com $\mathrm{N}-\mathrm{k}$ graus de liberdade, sendo $\mathrm{k}$ igual ao número de grupos que estejam sendo comparados (aqui, tem-se 40-5 = 35 graus de liberdade), então os grupos i e j tendem a diferir entre si.

Nestas condições, o p valor pode ser determinado calculando-se, por integração numérica, a área sob a curva da distribuição t com Nk (42) graus de liberdade, deixada acima do valor observado $b \mathrm{~b}$, obtido segundo a expressão:

$$
t_{o b}=\frac{\left|\frac{R_{i}}{n_{i}}-\frac{R_{j}}{n_{j}}\right|}{S^{2}\left(\frac{N-1-T}{N-k}\right)^{\frac{1}{2}}\left(\frac{1}{n_{i}}+\frac{1}{n_{j}}\right)^{\frac{1}{2}}} .
$$


Programa utilizado para realizar o teste de Kruskal-Wallis e as comparações múltiplas (já com os resultados)

Para realizar o teste de Kruskal-Wallis e efetuar as comparações múltiplas Fernandes, R.C. (2003) desenvolveu o seguinte programa utilizando o software R 1.7:

Obs.: Este programa só pode ser utilizado na situação onde temos 5 grupos com 8 indivíduos cada.

$>$ pop $<-5$
$>$ resp $<-c(57.9336,61.1454,55.4490,57.2064,57.6609,57.9942$, 58.2972,

+ 57.6306, 15.6348, 16.7256, 17.1195, 17.3619, 16.6953, 16.9983, 16.6650, +16.7862, 14.9076, 16.5135, 18.5739, 16.2408, 15.5136, 15.8772, 17.0286, +16.4226, 21.6342, 21.8160, 25.4217, 22.9977, 23.0886, 23.9976, 21.0888, +19.9677, 24.1491, 26.2398, $28.6638,27.4215,29.1789,28.4214,23.9067,+25.3611)$

$>\mathrm{R}<-$-numeric()

$>\mathrm{RR}<-\operatorname{matrix}(\mathrm{ncol}=5)$

$>\mathrm{R}<-$ rank(resp)

$\mathrm{R}$

[1] $37403334363839353101415912811 \quad 17165244136$ 
[26] 202721222418172528312932302326

$\mathrm{N}<$-length(resp)

$>k<-0$

$>$ for $(\mathrm{i}$ in $1: 5)\{$

+ soma $<-0$

$+\quad$ for(j in 1:8)\{

$+\quad$ soma $<-$ soma $+R[k+1]$

$+\quad \mathrm{k}<-\mathrm{k}+1\}$

$+\mathrm{RR}[i]<-$ soma $\}$

$>\mathrm{Rm}<-\mathrm{RR}^{\star}(1 / 8)$

$>\mathrm{Rm}$

$[, 1][, 2][, 3][, 4][, 5]$

[1,] $36.510 .256 .7521 \quad 28$

$>\mathrm{R} 2<-\mathrm{RR}^{\star} \mathrm{RR} \mathrm{R}^{\star}(1 / 8)$

$>\mathrm{R} 22<-\mathrm{R}^{*} \mathrm{R}$

$>\mathrm{msR} 2<-\operatorname{sum}(\mathrm{R} 2)$

$>\mathrm{sR} 2<-\mathrm{sum}(\mathrm{R} 22)$

$>$

$>\mathrm{S}<-(1 /(\mathrm{N}-1))^{\star}\left(\mathrm{SR} 2-\left(\left(\mathrm{N}^{\star}(\mathrm{N}+1)^{\star \star} 2\right) / 4\right)\right)$

$>\mathrm{T} 2<-(1 / \mathrm{S})^{\star}\left(\mathrm{msR} 2-\left(\left(\mathrm{N}^{\star}(\mathrm{N}+1)^{\star *} 2\right) / 4\right)\right)$

$>\mathrm{T} 2$

[1] 35.50976

$>$ pvalue1<-(1-pchisq $(\mathrm{T} 2,4))$

> pvalue1

[1] 3.649797e-07 
$\mathrm{B}<-\left(\left(\mathrm{S}^{*}(\mathrm{~N}-1-\mathrm{T} 2) /(\mathrm{N}-\mathrm{pop})\right)^{* *}(1 / 2)^{\star}((1 / 8)+(1 / 8))^{* *}(1 / 2)\right)$

$>$ A<-numeric()

$>$ for $(\mathrm{j}$ in $1: 4)$

+ for $(\mathrm{i}$ in $\mathrm{j}: 4)\{$

$+\mathrm{A}<-\mathrm{c}(\mathrm{A},(\operatorname{Rm}[\mathrm{j}]-\mathrm{Rm}[\mathrm{i}+1]))\}$

$>\mathrm{A}<-\operatorname{abs}(\mathrm{A})$

$>$ tobs $<-A / B$

$>$ tobs

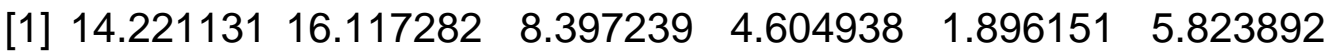
9.616193

[8] 7.72004311 .5123443 .792302

$>$ pvalue2<-(1-pt(tobs,35) $)^{*} 2$

$>$ pvalue2

[1] $\quad 4.440892 \mathrm{e}-16 \quad 0.000000 \mathrm{e}+00 \quad 6.636827 \mathrm{e}-10 \quad 5.258671 \mathrm{e}-05$ $6.621969 e-02$

[6] 1.317510e-06 2.336931e-11 4.609428e-09 1.878497e-13 5.667694e-04 